SUEl MASSUMI NAKATANI

\title{
Genotipagem do vírus da Hepatite C por PCR em tempo real com base na análise da região NS5B
}

Tese apresentada à Faculdade de Medicina da Universidade de São Paulo para obtenção do título de Doutor em Ciências.

Área de concentração: Gastroenterologia Clínica Orientadora: Prof. ${ }^{a}{ }^{\text {Dr. }}$. Suzane Kioko Ono-Nita

\section{São Paulo}


SUEl MASSUMI NAKATANI

\section{Genotipagem do vírus da Hepatite C por PCR em tempo real com base na análise da região NS5B}

Tese apresentada à Faculdade de Medicina da Universidade de São Paulo para obtenção do título de Doutor em Ciências.

Área de concentração: Gastroenterologia Clínica Orientadora: Prof. ${ }^{a}{ }^{\text {Dr. }}$. Suzane Kioko Ono-Nita

\section{São Paulo}


Às minhas filhas

Viviane, Lidiane e Cristiane por terem me dado o sentido do amor mais profundo.

Ao Tomi, esposo e companheiro por todos os momentos de amor e de alegrias compartilhados juntos, ao longo de todos esses anos.

A minha mãe Kayoko (in memorian) que me mostrou a beleza das flores e que me ensinou que o conhecimento é o bem mais precioso e ao meu pai Toru, pelo exemplo de vida. 
Ó SENHOR DEUS, eu te agradeço de todo o coração; Quando te chamei, tu me respondeste e, com o teu poder, aumentaste as minhas forças.

(Salmos 138, v.1,3) 


\section{AGRADECIMENTOS}

A todas as pessoas que contribuíram direta e indiretamente para a realização deste trabalho, e que tenho certeza, sem a colaboração de cada uma delas não teria chegado ao bom termo, o meu mais profundo agradecimento, em especial:

À Professora Dr. ${ }^{\text {a }}$ Suzane Kioko Ono-Nita, do Departamento de Gastroenterologia Clínica da Faculdade de Medicina da USP, orientadora deste trabalho, pelo apoio e que com o seu conhecimento acadêmico norteou todos os passos do trabalho, o meu sincero respeito e agradecimento.

O meu mar de agradecimento ao Carlos A. Santos, diretor cientifico do Laboratório Centro de Genomas, co-orientador deste trabalho que me direcionou e me inspirou em todos os passos fundamentais desta pesquisa, a minha mais sincera admiração e gratidão.

Ao Prof. Dr. Flair José Carrilho, por ter me dado a oportunidade de fazer o doutorado em uma instituição tão emérita como a Faculdade de Medicina da Universidade de São Paulo o meu Muito Obrigada!

Um agradecimento especial pelo apoio irrestrito, amizade à equipe da Seção de Biologia Molecular do Laboratório Central do Estado, Claudia Zen, Deborah Bubba e Helena Misugi. Em especial à minha amiga e companheira de equipe Irina N. Riediger, pelas correções, sugestões, apoio técnico e que muitas vezes nas nossas conversas de final de tarde direcionamos esta pesquisa.

A todos os pacientes que participaram desta pesquisa, a minha gratidão.

Um agradecimento especial a equipe do Laboratório de Gastroenterologia Clínica da Faculdade de Medicina da USP, em especial a Eliane do Carmo, Marcelo Tavares, Jerônimo Nogueira e Helena Paschoale que demonstraram um espírito de cooperação e boa vontade sempre que necessitei o meu especial agradecimento.

Ao Dr. Marcelo Nita, da USP, pelas análises estatísticas de correlação clínica deste trabalho o meu agradecimento especial. 
À direção do Laboratório Central do Estado, em particular ao Dr. Marcelo Pilonetto, Célia Fagundes da Cruz, que através dos seus incentivos possibilitou-me realizar todo o trabalho prático.

Ao Dr. Marco Aurélio Krieger do Instituto de Biologia Molecular do Paraná (IBMP) que possibilitou que esta pesquisa fosse contemplada na Fundação Araucária e desse modo contribuir com o suporte financeiro para o bom andamento desta pesquisa.

Um agradecimento especial ao Dr Hermes Pedreira da Silva Filho do Instituto Oswaldo Cruz (FioCruz Bahia), pela realização das análises filogenéticas deste trabalho.

Ao Dr. César Duarte, do Instituto de Biologia Molecular do Paraná - IBMP, pelo estímulo, amizade e correções deste trabalho.

Ao $\operatorname{Dr}$ Alexander W. Biondo, da Universidade Federal do Paraná do Departamento de Medicina Veterinária pela correções e sugestões.

Ao Prof. Dr. Stenio Perdigão Fragoso, do Instituto de Biologia Molecular do Paraná (IBMP), pelo exemplo como pesquisador e pelo apoio sempre que precisei.

À Prof. ${ }^{a}$ Dr. ${ }^{a}$ lara J. T. Messias-Reason, do Departamento de Patologia, Setor de Ciências da Saúde, da UFPR, orientadora da minha dissertação de mestrado e que sempre ora por mim e me incentiva a continuar no caminho da pesquisa.

À Dr. ${ }^{a}$ Marion Burger, do Instituto de Pesquisa Pelé (IPP), pela amizade, pelo exemplo, pelo incentivo sempre presente e correções.

À Dr. ${ }^{a}$ Jacqueline Mendes de Oliveira, do Instituto Oswaldo Cruz (IOCFioCruz/RJ) pela amizade, correções, e pela cessão dos "primers" e acesso aos protocolos de PCR, o que possibilitou utilizar os grupos-controles patológicos de hepatite A.

À Seção de Imunologia do LACEN-PR, nas pessoas de Yatiyo Moriya e Florise Weniger Spelling, pelas amostras cedidas para o controle patológico de hepatite A e hepatite B.

À equipe médica do Departamento de Gastroenterologia do Hospital de Clínicas da UFPR, em especial à Dr. ${ }^{a}$ Claudia Ivantes, $\mathrm{Dr}^{2}{ }^{a}$ Maria Lúcia Pedroso, 


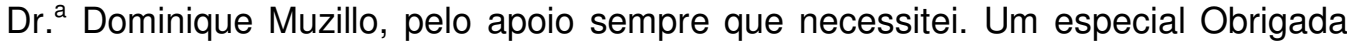
ao Dr. Marco Aurélio de Lacerda, da Universidade de Indianápolis, que sempre me incentivou em vários momentos, desde que comecei a trabalhar com o vírus da hepatite B e C.

À Celina de Oliveira Poersch, do Instituto de Biologia Molecular do Paraná (IBMP), pela doação das amostras para controle patológico de dengue e acesso aos respectivos resultados de PCR.

À Prof. ${ }^{a}$ Dr. ${ }^{a}$ Claudia Nunes dos Santos, do Instituto de Biologia Molecular do Paraná (IBMP), pela cessão dos primers e acesso aos protocolos de dengue e cooperação sempre que necessitei.

Ao Prof. Dr. Bonald Cavalcante Figueiredo, do Instituto Pelé (IPP), por gentilmente ter me cedido o laboratório de Biologia Molecular para uma parte da padronização do método desenvolvido.

À Secretaria do Estado de Saúde do Paraná e Fundação Araucária, pelo suporte financeiro desta pesquisa.

Ao Núcleo de Estudos de Bacteriologia (NEBAC), pela longa caminhada juntos, sempre percorrendo o caminho do estudo.

A todos os colegas do LACEN, que sempre me incentivaram com palavras de apoio, incentivo e amizade.

E a todas as pessoas que não citei, mas que estão presentes em minha vida, e faz com que ela seja feita de amizades, carinho e alegrias. 
OUVE A EXORTAÇÃO DA AURORA CUIDA DESTE DIA

POIS É A VIDA, A PRÓPRIA VIDA DA VIDA. EM SEU BREVE CURSO RESIDEM TODAS AS VERDADES E A REALIDADE DA TUA EXISTENNCIA, A BENÇÃO DO CRESCIMENTO,

A GLÓRIA DA AÇÃO, O ESPLENDOR DA BELEZA, POIS ONTEM É APENAS UM SONHO,

E AMANHÃ, APENAS UMA VISÃO, MAS HOJE BEM VIVIDO TORNA CADA ONTEM UM SONHO DE FELICIDADE E CADA AMANHÃ UMA VISÃO DE ESPERANÇA. CUIDA BEM, POIS, DESTE DIA.

(REGISTRO VEDA SANSCRITO-500.A C) 
Esta tese está de acordo com as seguintes normas, em vigor no momento da publicação:

Referências: adaptado de International Committee of Medical Journals Editors (Vancouver)

Universidade de São Paulo. Faculdade de Medicina. Serviço de Biblioteca e Documentação. Guia de apresentação de dissertações, teses e monografias. Elaborado por Anneliese Carneiro da Cunha, Maria julia de A.L. Freddi, Maria F. Crestana, Marinalva de Souza Aragão, Suely Campos Cardoso, Valéria Vilhena, $2^{\mathrm{a}}$ ed. São Paulo: Serviço de Biblioteca e Documentação; 2005.

Abreviaturas dos títulos dos periódicos de acordo com List of Journals Indexed in Index Medicus 


\section{SUMÁRIO}

\section{LISTA DE TABELAS \\ LISTA DE FIGURAS \\ LISTA DE ABREVIATURAS, SIGLAS E SÍMBOLOS \\ RESUMO \\ SUMMARY}

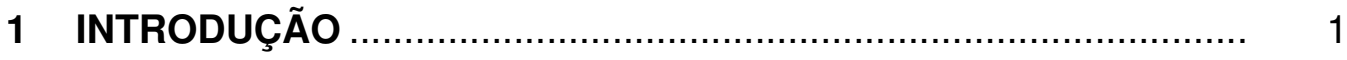

1.1 Justificativa ...........................................................................

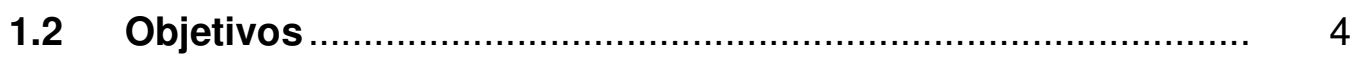

1.2.1 Objetivo geral .....................................................................

1.2.2 Objetivos específicos ........................................................... 4

2 REVISÃO DE LITERATURA..................................................... 5

2.1 Estrutura do vírus e integração do VHC na célula do hospedeiro .................................................................. 5

2.2 Organização genômica do VHC .............................................

2.3 Processamento da Poliproteína .............................................. 8

2.4 Estrutura e funções das proteínas do VHC............................. 9

2.4.1 Proteínas estruturais ........................................................... 9

2.4.2 Proteínas não-estruturais ......................................................... 10

2.5 Diversividade genética do VHC ........................................... 12

2.6 Classificação do VHC .............................................................. 13

2.7 Distribuição geográfica dos genótipos do VHC ..................... 14

2.8 Relevância clínica ........................................................... 17

2.8.1 Correlação entre genótipos e doenças hepáticas ........................ 17

2.8.2 Correlação entre genótipos e transplante hepático...................... 18

2.8.3 Tratamento em relação aos genótipos ........................................ 18

2.9 Identificação dos genótipos do VHC ……………………....... 21

2.9.1 Escolha da região do VHC para genotipagem .......................... 21

2.9.2 Métodos de genotipagem não comerciais.................................. 21

2.9.3 Métodos comerciais para genotipagem do $\mathrm{VHC} \ldots \ldots \ldots \ldots \ldots \ldots \ldots \ldots \ldots . . . . . . . . . . .35$ 
3 MÉTODOS

I SEQÜENCIAMENTO DAS AMOSTRAS PARA DESENHO DE SONDAS E "PRIMERS" PARA GENOTIPAGEM DO VHC POR PCR EM TEMPO REAL................................................................... 44

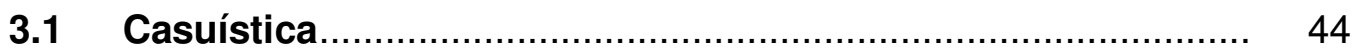

3.2 Comitê de Ética .................................................................... 45

3.3 Amostras de plasma ....................................................... 45

3.4 Extração do RNA …............................................................ 46

3.5 Procedimentos para a realização da PCR ………………….... 47

3.5.1 Desenho dos "primers" ....................................................... 47

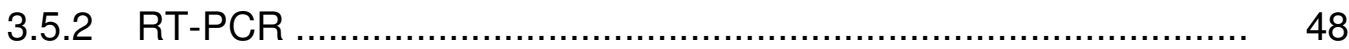

3.5.3 Padronização da reação de PCR ……………............................ 49

3.5.4 PCR da região NS5B do VHC ................................................. 49

3.5.5 Deteç̧ão e análise do produto da PCR ………......................... 49

3.6 Seqüenciamento da Região NS5B do VHC ............................ 50

3.6.1 Purificação dos produtos da PCR ............................................. 50

3.6.2 Quantificação do produto purificado........................................... 51

3.6.3 Reação de seqüênciamento ………………............................. 51

3.6.4 Purificação dos produtos seqüenciados..................................... 52

3.6.5 Seqüenciamento dos produtos ............................................. 53

3.6.6 Análises das seqüências........................................................... 53

3.6.7 Número de acesso no GenBank ............................................... 53

3.7 Genotipagem do VHC pelo método LiPA ……...................... 54

II DESENVOLVIMENTO E PADRONIZAÇÃO DA TÉCNICA DE PCR EM TEMPO REAL PARA A GENOTIPAGEM DO VHC.........55

3.8 Desenhos de "primers" e sondas ............................................. 56

3.9 Extração do RNA …………………………………........ 58

3.10 Gradiente de temperatura dos "primers" ............................... 59

3.11 Padronização da PCR em tempo real "two step" ................... 59

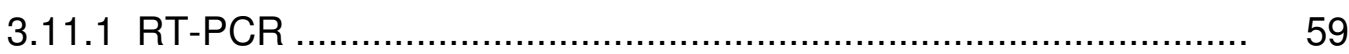

3.11.2 Realização de matrizes com diferentes concentrações de "primers" e sondas 
3.12 Padronização da PCR em tempo real "one step" .................. 60

3.12.1 Reação de PCR em tempo real "one step" .............................. 60

III TESTES DE VALIDAÇÃO DA PCR EM TEMPO REAL ONESTEP" MODIFICADA ................................................... 64

3.13 Intrepretação de Resultados ............................................. 64

3.14 Determinação da eficiência da reação "monoplex" e 'triplex" para os diferentes genótipos 1a, 1b, 2b, e 3a ........... 65

3.15 Determinação da acurácia do método.................................... 65

3.16 Análises das seqüências............................................... 65

3.17 Análises Filogenéticas ................................................. 65

3.18 Números de acesso ao GenBank ........................................ 66

3.19 Comparação das genotipagens do VHC realizados pelos métodos LiPA e PCR em tempo real................................. 66

3.20 Pesquisa qualitativa e quantitativa do vírus da hepatite C..... 68

3.21 Determinação da sensibilidade analítica do método .............. 68

3.22 Determinação da sensibilidade relativa do método................ 68

3.23 Determinação da reprodutibilidade do método ....................... 69

3.24 Determinação da especificidade do método.......................... 70

3.25 Detecção de múltiplos genótipos através da mistura de RNA de diferentes pacientes .............................................. $\quad 70$

3.26 Detecção de múltiplos genótipos através de diluições de parâmetro final ............................................................. 70

3.27 Pesquisa de reação cruzada com genótipos 4 e $5 \ldots \ldots \ldots \ldots \ldots \ldots . . . . . .71$

3.28 Pesquisa de reação cruzada com vírus da hepatite A e B....... 71

3.29 Pesquisa de reação cruzada com o vírus - HIV ...................... 72

3.30 Pesquisa de reação cruzada com o vírus da dengue............... 72

3.31 Algoritmo sugerido para laboratório de saúde pública para a realização da genotipagem do VHC por PCR em tempo real ................................................................ 73

3.32 Análise estatística ..................................................... 74

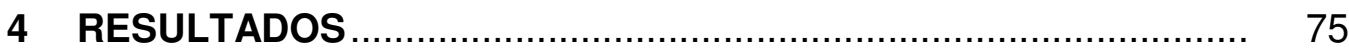

I SEQÜENCIAMENTO DAS AMOSTRAS PARA DESENHO 
DE SONDAS "PRIMERS PARA GENOTIPAGEM DO VHC POR PCR E M TEMPO REAL ........................................... 75

4.1 Desenhos dos "primers" .............................................. 75

4.2 Padronização da reação da PCR ........................................... 76

4.3 Comparação dos genótipos do VHC pelos métodos de seqüenciamento da região NS5B e pelo método comercial LiPA (região 5'UTR) .................................................... 77

4.4 Determinação de infecção por múltiplos genótipos ................ 79

$4.5 \quad$ Artigo submetido .......................................................... 79

II DESENVOLVIMENTO E PADRONIZAÇÃO DA TÉCNICA DE PCR EM TEMPO REAL PARA A GENOTIPAGEM DO VHC....... 80

4.6 Desenho dos "primers" e sondas .................................. 80

4.7 Realização de matriz de titulação para verificar a concentração ótima de "primers" e sondas

4.8 Padronização da transcrição reversa e amplificação em sistema "one-step" para a genotipagem por PCR em tempo real do VHC

4.9 Comparação das sondas 1 b266 e 1b66; 3a66 e 3a266..

4.10 Determinação da eficiência da reação para os diferentes genótipos 1a, 1b, $2 b$ e $3 a$ quanto aos sistemas "monoplex" e "triplex"

III TESTES DE VALIDAÇÃO DA GENOTIPAGEM POR PCR EM TEMPO REAL EM SISTEMA "ONE-STEP MODIFICADO ....

4.11 Determinação da acúrácia do método de genotipagem por PCR em tempo real ............................................. 84

4.12 Análises filogenéticas .................................................. 85

4.13 Genotipagem do VHC por PCR em tempo real ..................... 86

4.14 Comparação da genotipagem do VHC pelos métodos LiPA e PCR em tempo real

4.15 Identificação de múltiplos genótipos pelo método de genotipagem por PCR em tempo real 
4.16 Detecção de múltiplos genótipos através de detecção de diluição em parâmetro final.

4.17 Detecção de múltiplos genótipos através da mistura de RNA de diferentes pacientes................................................... 94

4.18 Determinação da sensibilidade analítica do método ……....... 94

4.19 Determinação da sensibilidade relativa do método................. 95

4.20 Determinação da reprodutibilidade do método ....................... 95

4.21 Determinação da especificidade do método de genotipagem por PCR em tempo real.................................... 96

4.22 Pesquisa de reação cruzada com genótipos 4 e 5 ………...... 96

4.23 Pesquisa de reação cruzada com hepatite viral não C ............ 96

4.24 Pesquisa de reação cruzada com o vírus - HIV e o vírus da dengue ................................................................... 97

4.25 Custo da reação de genotipagem por PCR em tempo real...... 97

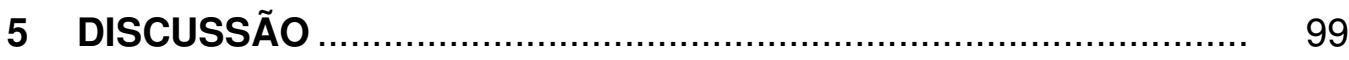

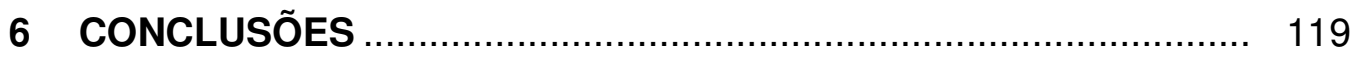

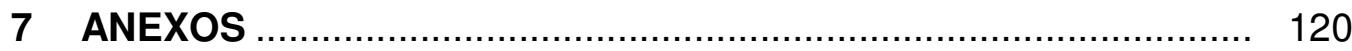

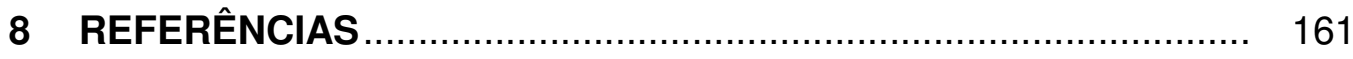




\section{LISTA DE TABELAS}

Tabela 1 - Comparação dos métodos moleculares comerciais com o seqüenciamento (padrão ouro) para a genotipagem do $\mathrm{HC}$.

Tabela 2 - "Primers"'"utilizado para a amplificação da região NS5B do VHC

Tabela 3 - Relação dos "primers"utilizados para a amplificação da região NS5B do VHC

Tabela 4 - Relação das sondas utilizadas no método de genotipagem do VHC por PCR em tempo real.

Tabela 5 - Comparação dos resultados de genotipagem obtidos pelo LiPA (5'UTR) e com seqüênciamento da região NS5b do VHC

Tabela 6 - Comparação entre LiPA (5'UTR) e seqüênciamento da região NS5B do VHC das amostras com subtipos discordantes, incompletos, indefinidos ou de misturas de genótipos

Tabela 7 - Matriz dos diferentes genótipos com os valores da média de Cts.

Tabela 8 - Cts de diferentes protocolos "one-step" "monoplex" e "duplex".....

Tabela 9 - Eficiência das reações para os diferentes genótipos em sistemas "monoplex" e "triplex".

Tabela 10 - Comparação dos métodos de seqüênciamento e PCR em tempo real Ipara a genotipagem do VHC

Tabela 11- Comparação dos métodos de genotipagem por PCR em tempo real e LiPA

Tabela 12- Números de amostras com subtipos discordantes ou resultados incompletos pelo LiPA (5'UTR) quando comparados com genotipagem por PCR em tempo real da região NS5B do VHC

Tabela 13 - Cts das diferentes sondas nas amostras que deram misturas de genótipos por genotipagem por PCR em tempo real do $\mathrm{VHC}$

Tabela 14 - Valores em reais dos valores por reação para cada teste de genotipagem por PCR em tempo real 


\section{LISTA DE FIGURAS}

Figura 1 - Internalização do VHC na célula do hospedeiro

Figura 2 - Organização genética e processamento da poliproteína do VHC

Figura 3 - Distribuição geográfica dos diferentes tipos e subtipos ao redor do mundo

Figura 4 - Distribuição dos genótipos do VHC em diferentes regiões do Brasil.

Figura 5 - Representação esquemática do genoma do VHC, com proteínas estruturais e não estruturais

Figura 6 - Esquema dos diferentes passos necessários para a realização do seqüênciamento

Figura 7 - llustração do mecanismo da plataforma TaqMan que através da atividade exonucléasica da Taq polimerase quebra a sonda separando a sonda "reporter do "quencher" e a fluorescência emitida pelo "reporter" ser captada pelo sistema ótico

Figura 8 - llustração dos passos necessários para a realização da genotipagem através da técnica de hibridização reversa-LiPA

Figura 9 - llustração do esquema de genotipagem pelo método de seqüênciamento TRUGENE 5'UTR

Figura 10 - Ilustração do método "Invader" para a genotipagem do VHC

Figura 11 - llustração do esquema de genotiapgem do VHC por PCR em tempo real HCV-ASR

Figura 12 - Representação esquemática do desenho dos "primers" e sondas dos genótipos 1 e 3 marcadas com os respectivos fluoróforos da região NS5B do VHC

Figura 13 - Representação esquemática dos desenhos dos "primers" e sondas do genótipo 2 marcadas com os respectivos fluoróforos da região NS5B do VHC

Figura 14 - Representação esquemática da genotipagem por PCR em tempo real "one step" modificada 
Figura 15 - PCR com "primers" NS5B2F/NS5B2R da região NS5B do VHC que amplificam genótipos de 1 a 6 .

Figura 16 - PCR com "primers" GEN2FSN/GEN2RSN da região NS5B do VHC que amplificam o genótipo 2

Figura 17 - PCR com "primers" F56_1-3/R56_1-3 da região NS5B do VHC que amplificam o genótipo3

Figura 18 - Árvore filogenética, enraizada de 150 seqüências (138 seqüências deste estudo e 14 com seqüências referências obtidas do GenBank) da região NS5B com 216 pb; posição 1223-1438 na região NS5B de acordo com seqüência referência H77.NC_004102

Figura 19 - Fluxograma das amostras genotipadas por PCR em tempo real

Figura 20 - Seqüências geradas através do programa Secscape. As flechas em vermelho mostram as 2 mutações que ocorreram na região das sondas

Figura 21 - Amplificação dos diferentes genótipos por PCR em tempo real..... 


\section{LISTA DE ABREVIATURAS, SIGLAS E SÍMBOLOS}

\begin{tabular}{|c|c|}
\hline$\%$ & Porcentagem \\
\hline$\geq$ & Maior igual \\
\hline$\beta$ & Beta \\
\hline$\mu \mathrm{g}$ & Microgramas \\
\hline$\mu l$ & Microlitro \\
\hline$\mu \mathrm{m}$ & Micra \\
\hline$A$ & Adenina \\
\hline $\mathrm{C}$ & Citosina \\
\hline $\mathrm{Ca}^{++}$ & Cálcio \\
\hline CCD & Couple device charge \\
\hline CD4 & Marcador de Membrana de Linfócitos T auxiliares \\
\hline cDNA & DNA complementar \\
\hline cels & Células \\
\hline $\mathrm{Ct}$ & Ciclo treshold \\
\hline DNA & Ácido Desoxiribonucléico \\
\hline dNTPS & Desoxiribonucleosideo Trifostato \\
\hline $\mathrm{E} 1$ & Glicoproteínas do envelope 1 \\
\hline E2 & Glicoproteínas do envelope 2 \\
\hline G & guanina \\
\hline HIV & Vírus da Imunodeficiência Humana \\
\hline IFN- $\alpha$ & Interferon- alfa \\
\hline $\lg M$ & Imunoglobulina M \\
\hline IRES & Sítio interno de entrada no ribossomo \\
\hline ISDR & Região determinante de sensibilidade \\
\hline $\mathrm{Kb}$ & Kilobase \\
\hline Kda & Quilodaltons \\
\hline LDL & Lipoproteínas de baixa densidade \\
\hline LDLR & Lipoproteínas de muito baixa densidade \\
\hline MGB & Minor groove binder \\
\hline $\mathrm{MgSO}_{4}$ & Sulfato de magnésio \\
\hline
\end{tabular}




\begin{tabular}{ll} 
min. & Minutos \\
nM & Nanomolar \\
NS2, NS3, NS4, NS5A & Proteínas não estruturais do genoma do VHC \\
NS5B & Proteínas não estruturais 5B \\
oC & Graus celsius \\
pb & Pares de Base \\
PCR & Reação em Cadeia da Polimerase \\
pH & Potencial Hidrogeniônico \\
PKR & Proteína quinase ds-RNA dependente \\
pM & Pico moles \\
RdRp & RNA polimerase RNA dependente \\
RE & Reticulo endoplasmático \\
RLU & Unidades Relativa de luminescência \\
RNA & Ácido Ribonucléico \\
RT & Transcrição reversa \\
RVS & Reposta viral sustentada \\
S & Segundos \\
SR-BI & Receptores scavange de classe B tipo 1 \\
T & Timina \\
Tm & Temperatura de melting \\
UTR & Região não traduzida \\
V/V & Volume- Volume \\
VHA & Vírus da hepatite A \\
VHB & Vírus da hepatite B \\
VHC & Vírus da hepatite C \\
& \\
\hline &
\end{tabular}




\section{RESUMO}

Genotipagem do vírus da Hepatite $C$ por PCR em tempo real com base na análise da região NS5B.

A genotipagem do vírus da hepatite $\mathrm{C}(\mathrm{VHC})$ é a principal ferramenta para prognóstico e tempo de tratamento. Dependendo do genótipo infectado existem diferentes esquemas e tempo de tratamento. O objetivo deste trabalho foi desenvolver padronizar e validar um método de genotipagem por PCR em tempo real com base na análise da região NS5B. Esta região apresenta um grau de polimorfismo que permite identificar de modo mais acurado tanto os tipos como os subtipos do VHC. Para isto foram desenhados dois conjuntos de "primers" e sondas. Neste trabalho desenvolvemos um método "one-step" modificado em uma reação "triplex" em que ocorre a identificação dos genótipos (1a, 1b, 3a) e em outro set a identificação dos genótipos $(2 \mathrm{a}, 2 \mathrm{~b}, 2 \mathrm{c})$. Os resultados obtidos pelo método de genotipagem em tempo real concordaram em $100 \%$ com os resultados de seqüênciamento da região NS5B quando excluímos amostras que foram identificados como mistura de genótipos no método desenvolvido e classificados somente como um único genótipo no seqüênciamento. Houve uma boa concordância entre o método desenvolvido e o seqüênciamento da região NS5B pelo coeficiente de Kappa $(\kappa=0,6222 ; p=0,0020)$. $O$ método de desenvolvido conseguiu detectar 97,93\% (190/194) do genótipo 1 , $86,11 \%(31 / 36)$ do genótipo 2 e 100\% (80/80) do genótipo 3. A média da sensibilidade foi de $97 \%$. Quando comparamos a genotipagem por PCR em tempo real e LiPA nas 310 amostras analisadas não houve resultados discordantes em relação ao genótipo. Entretanto, 26,24\% (79/301) das amostras analisadas apresentaram resultados discordantes em relação ao subtipo quando comparados os dois métodos. Foi determinada a sensibilidade analítica do método através de um ponto do painel da OptiQuant que foi diluído de modo seriado e a sensibilidade relativa foi realizada através de amostras de plasma de pacientes com carga viral determinada pelo Cobas Amplicor. O limite mínimo de detecção determinado foi de $125 \mathrm{Ul} / \mathrm{ml}$ para o genótipo 3a, $250 \mathrm{Ul} / \mathrm{ml}$ para o genótipo $1 \mathrm{~b}$ e $2 b$ e $500 \mathrm{Ul} / \mathrm{ml}$ para 0 genótipo 1a. Somados a isso, o método desenvolvido tem um custo de $R \$ 58,00$, um valor nove vezes menor que o método comercial utilizado em nosso laboratório. Além disso, no método desenvolvido, o tempo trabalhado cai para menos de 2 horas sem a necessidade de manipulação constante em comparação com LiPA que necessita em torno de 16 horas, devido ao vários passos de hibridizações e lavagens. No presente trabalho o método de genotipagem por PCR em tempo real para o VHC mostrou-se eficiente e capaz de identificar de um modo acurado os diferentes genótipos e seus subtipos e contribuir para um entendimento melhor do verdadeiro papel dos genótipos e seus subtipos e da variabilidade genética na história natural da infecção do VHC.

Descritores: 1. Hepacivirus 2. Reação em cadeia da polimerase via transcriptase reversa 3. Prognóstico 


\title{
SUMMARY
}

\author{
Genotyping of Hepatitis C vírus by Real Time PCR based in analysis of NS5B \\ region
}

Hepatitis $\mathrm{C}$ virus (HCV) genotyping is the most significant predictor of response to antiviral therapy. Depending on the infecting HCV genotyping different antiviral regimens have been proposed as well as the length of different treatment. The aim of this study was to develop and evaluate a new real time PCR of HCV genotyping based in NS5B region. This region has sequencing heterogeneity and can accurately identify both type and subtype of HCV. Furthermore, we compared the real time PCR with LiPA and sequencing of NS5B region. We developed a new one-step modified method in triplex reaction where we identified in two sets genotypes (1a, 1b, 3a) and (2a, 2b, 2c). Results obtained by real time PCR agreed $100 \%$ with those obtained by NS5B sequencing when excluded samples with mixed of HCV genotypes identified by real time PCR genotyping and in NS5B sequencing all samples were classified only as only one genotype. We found a good concordance for the analysis of genotype concordance between genotyping by real time and sequencing of NS5B region through the coefficient kappa $(\kappa=0,6222 ; \mathrm{p}=0,0020)$. The method developed detected $97,93 \%(190 / 194)$ of genotype $1,86,11 \%(31 / 36)$ of genotype 2 and $100 \%$ (80/80) of genotype 3 , with the overall sensitivity of this new method being $97 \%$. Among 310 samples only two samples had discordant results at type level when comparing real time PCR and LiPA. However, 26,24\% (79/301) had discordant results at subtype level when comparing LiPA and real time PCR genotyping of $\mathrm{HCV}$. In order to measure the analytical sensitivity of the real time assay, one member of the panel OptiQuant HCV RNA was diluted. The relative sensitivity was determined by analysis the clinical specimens based upon the initial HCV RNA concentration determined by Cobas Amplicor. The lower limit of detection was estimated to be $125 \mathrm{IU} / \mathrm{ml}$ for genotype $3 \mathrm{a}, 250 \mathrm{IU} / \mathrm{ml}$ for genotype $1 \mathrm{~b}$ and $2 \mathrm{~b}$, and $500 \mathrm{IU} / \mathrm{ml}$ for genotype $1 \mathrm{a}$. Finally, the cost of each reaction are about $\mathrm{R} \$ 58,00$ nine fold lower than the commercial method available in Brazil. Manipulation time of real time PCR genotyping is about 2 hours, in comparison to LiPA that requires about 16 hours due to various hybridization steps and washing. This study was demonstrated an efficient method of identification in a accurate way. HCV genotyping which is important to understand the role of genotypes and subtypes, as well as of genomic variability in the natural history of HCV infection.

Descriptors: 1 . Hepacivirus 2. Polymerase chain reaction by reverse transcriptase 3. Prognostic 


\section{INTRODUÇÃO}

O vírus da hepatite $\mathrm{C}(\mathrm{VHC})$ foi o principal agente etiológico de hepatite pós-transfusional, originalmente denominada de não-A, não-B. O VHC infecta mais de 170 milhões de pessoas no mundo o que equivale a 3\% da população mundial (1). No Brasil, segundo dados do Ministério da Saúde, estima-se que $1,5 \%$ da população seja portadora do vírus (2). O VHC é a principal causa de hepatite crônica, cirrose hepática e carcinoma hepatocelular em todo mundo (3) (4) (5). As infecções crônicas ocorrem em 50-80\% dos casos, podendo evoluir para cirrose hepática em aproximadamente $10-20 \%$ dos casos e desta para carcinoma hepatocelular na taxa de 1-4\% (6).

O tratamento padrão para os pacientes com infecção crônica é a combinação do interferon peguilado com ribavirina. Vários critérios são utilizados para o prognóstico da evolução da doença, como carga viral, idade, sexo e extensão da fibrose hepática. Mas sobre todos esses fatores, o genótipo do vírus da hepatite $C$ é o fator mais importante na predição de resposta ao tratamento antiviral. Cerca de 70 a 80\% dos pacientes infectados com genótipo 2 obtêm resposta viral sustentada (RVS). Dependendo da situação histológica do fígado, considerando a presença de fibrose e esteatose, os pacientes infectados com o genótipo 3 podem apresentar RVS em torno de $70 \%$. Já os pacientes infectados com o genótipo 1 obtêm RVS em apenas 40 a 50\% dos $\operatorname{casos}(7)$. 
Desse modo, a genotipagem do vírus da hepatite C é uma importante ferramenta para o entendimento da evolução e epidemiologia do vírus, além de determinar o prognóstico e o tempo de tratamento. Além disso, os genótipos do VHC estão relacionados em diferentes estudos de epidemiologia, cinética viral, pós-transplante hepático e também com diversas doenças hepáticas como a esteatose.

As técnicas de biologia molecular, ou seja, a análise e caracterização do material genético representam um recurso extremamente importante para um diagnóstico rápido e eficaz. Diferentes métodos moleculares de genotipagens, comerciais e não-comerciais, são empregados, entre eles, o seqüênciamento de diferentes regiões do genoma, a caracterização através "primers" específicos, análise de polimorfismo de tamanho de fragmentos de restrição (RFLP) e a hibridização reversa com sondas específicas. A maioria destes métodos apresenta prós e contras descritos a seguir na revisão de literatura.

Com a introdução de novas tecnologias, como a PCR em tempo real, novas possibilidades de métodos mais sensíveis, rápidos, eficazes e de menor custo para a genotipagem do VHC puderam ser desenvolvidas. O presente trabalhou focou no desenvolvimento, padronização e validação de um método de genotipagem por PCR em tempo real utilizando como alvo a região NS5B do VHC. Para isso, foram seqüênciadas amostras de diferentes genótipos e a partir destas, foram desenhadas as sondas e "primers" para os genótipos em dois "sets" de reações (1a, 1b, 3a) e (2a, 2b, 2c). Sendo o VHC um vírus RNA, o desenvolvimento e padronização do método envolveram diferentes etapas para alcançar um diagnóstico preciso, como a escolha entre os 
sistemas "two-step" e "one-step". Além disso, diferentes procedimentos foram realizados para a validação do método de genotipagem por PCR em tempo real. Foram comparadas amostras entre o método desenvolvido e o método comercial LiPA (VERSANTTM HCV Genotype assay). Para verificar a acurácia do método foram comparadas com sequênciamento da região NS5B. Isto possibilitou a subtipagem dos genótipos de um modo mais acurado que os métodos comerciais focados na região 5'UTR (região não traduzida).

\subsection{Justificativa}

O Laboratório Central do Estado (LACEN-PR), atualmente, realiza a genotipagem do VHC para toda a rede pública de saúde do Estado do Paraná. Desde o ano 2002, ano em que a técnica foi implantada, foram realizados mais de 2800 testes de genotipagem para os diversos serviços de saúde. Os testes são realizados pelo kit comercial VERSANTTM HCV Genotype assay (LiPA). Porém, estes apresentam um alto custo: cada teste realizado tem um custo financeiro de $R \$ 550,00$. Nestes custos estão incluídos os testes HCV Amplicor versant 2.0 Roche, usados para a amplificação do RNA viral e o LiPA, para a genotipagem. Não estão incluídos os insumos, a mão-de-obra e o desgaste dos equipamentos. Além disso, o tempo necessário para a realização deste teste é longo, levando em média 2 dias para a genotipagem de 22 amostras. Em relação à caracterização dos diferentes genótipos e respectivos subtipos, a identificação fica prejudicada principalmente em relação ao genótipo 1, já que uma grande parte das amostras são identificadas sem o subtipo. 
Em contrapartida o desenvolvimento da PCR em tempo real, com a utilização de sondas marcadas enfocando a região NS5B, pôde levar a uma maior acurácia na identificação dos diferentes tipos e subtipos do VHC. Além disso, a técnica poderá proporcionar menor tempo de realização e redução de custos.

\subsection{Objetivos}

\subsubsection{Objetivo geral}

Desenvolver, padronizar e validar um método para identificação de diferentes genótipos do VHC pela técnica da PCR por tempo real com base no estudo da região NS5B.

\subsubsection{Objetivos específicos}

- Comparar os resultados de genotipagem de 310 amostras pelo método de LiPA e o método de PCR em tempo real desenvolvido.

- Comparar os resultados de genotipagem por PCR em tempo real e seqüênciamento parcial da região NS5B para verificar a acurácia do método. 


\section{REVISÃO DE LITERATURA}

\subsection{Estrutura do vírus e entrada do VHC na célula do hospedeiro}

O vírus da hepatite C (VHC) foi identificado em 1989, por Choo e colaboradores (8) e está atualmente classificado no gênero Hepacivirus da família Flaviviridae (9). A partícula viral do VHC, que apresenta tamanho variável de 40 a 70 nm de diâmetro é composta por nucleocapsídeo, circundado por envelope de constituição lipoprotéica, com as glicoproteínas E1 e E2 (10). As proteínas do "core" e as glicoproteínas E1 e E2 são as principais proteínas do viríon (11).

O vírus da hepatite $\mathrm{C}$ infecta somente o homen e o modelo no chimpanzé. Apesar do escasso entendimento dos detalhes da entrada da partícula viral na célula do hospedeiro, recentes estudos demonstram que é um processo complexo que envolve diferentes passos. Os hepatócitos são o principal alvo, mas outras células como células B, células dendríticas podem ser infectadas. Um dos principais receptores descrito é CD81 que provavelmente se liga com a glicoproteína E2 (12), uma proteína encontrada na superfície de diferentes tipos de células como hepatócitos, receptores escavanger, classe B tipo I (SR-BI) (13) e mais recentemente "claudin-I" (14). O VHC circula de várias formas nas células infectadas do hospedeiro e pode estar associado também com lipoproteínas de baixa densidade (LDL) e de muito baixa densidade (VLDL). Ambos representam a fração que circula como viríons ligados às imunoglobulinas ou como vírions livres (15). Através destes, os vírus se ligam nas superfícies das células do hospedeiro e a sua entrada 
pode envolver diferentes tipos de receptores. Uma delas, claudin-I, tem como função em estágios mais avançados da entrada na célula como ligação nos hepatócitos polarizados (16). O vírus entra na célula por endocitose mediada por clatrina e presume-se que ocorra fusão de peptídeos do envelope viral à membrana do endossoma, mediado por baixo $\mathrm{pH}$ (17). Como demonstrado para outros flavivírus, as proteínas do envelope possuem peptídeos de fusão internos que, em baixo pH, são expostos mediante arranjo e trimerização da proteína (18). Há vários trabalhos sugerindo que a entrada de todos os vírus da família Flaviviridae, incluindo o VHC é realizado através de proteínas de fusão classe II. Entretanto, os mecanismos envolvendo a ativação do VHC em pH baixo, os passos da fusão e a identificação dos peptídeos de fusão não estão bem carcterizados (19). O modelo corrente da internalização do VHC está esquematizado na Figura 1.

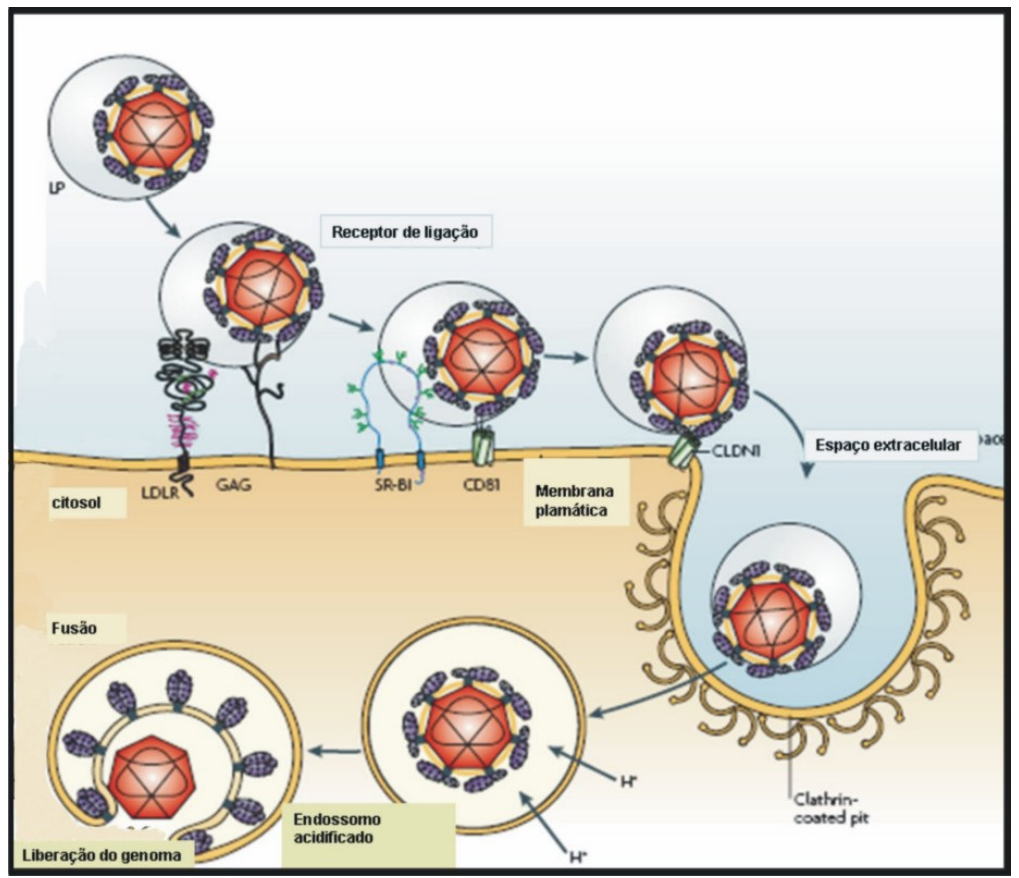

Figura 1 - Internalização do VHC na célula do hospedeiro FONTE: Moradpour et al. (2007) 


\subsection{Organização genômica do VHC}

O genoma do VHC é constituído por RNA de fita simples com polaridade positiva, composta por aproximadamente 9600 nucleotídeos (8). Contém uma única fase de leitura aberta (ORF, "open reading frame") que codifica para uma poliproteína de cerca de 3.000 aminoácidos. O genoma possui duas regiões não traduzidas: 5’UTR com aproximadamente 341 nucleotídeos; e região 3'UTR com aproximadamente 230 nucleotídeos. A região 3'UTR (região não traduzida) é composta de uma região variável de 80 nucleotídeos, um trato poli U/UC, de comprimento variável e uma região altamente conservada de aproximadamente 98 nucleotídeos chamada cauda X, importantes para a replicação e infecciosidade do VHC (20). Ambas as regiões são altamente conservadas e essenciais para a tradução protéica e para a replicação do genoma viral in vivo (21). A região 5'UTR é composto de 4 domínios, I à IV. Os domínios II, III e IV da região 5'UTR, junto com os primeiros 24-40 nucleotídeos da região do core constituem o sítio interno de entrada do ribossomo (IRES). A tradução da poliproteína do VHC inicialmente ocorre através da formação de um complexo binário entre o IRES e a subunidade $40 S$ do ribossomo e a iniciação da tradução de uma forma cap - independente do RNA viral (22).O complexo IRES-40S recruta o fator de iniciação eucarioto (elF) 3 e o complexo ternário Met-tRNA-elF2-GTP para a associação com a subunidade 60S formando o complexo ativo $80 \mathrm{~S}$ (23).

O desenho esquemático da organização do genoma do VHC está representado na Figura 2. 


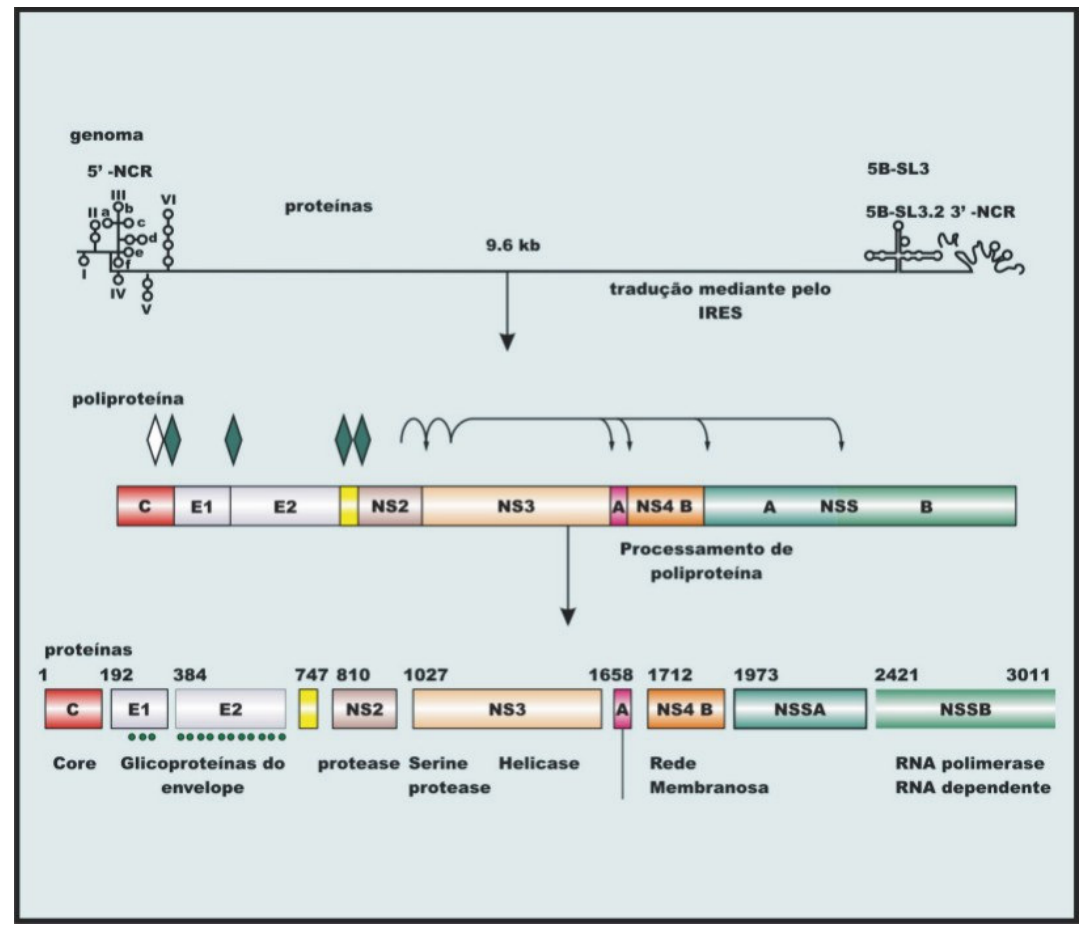

Figura 2 - Organização genética e processamento da poliproteína do VHC FONTE: Moradpour et al. (2007)

\subsection{Processamento da Poliproteína}

A tradução do RNA do VHC resulta numa poliproteína precursora que sofre processamento proteolítico co- e pós- tradução (mediado por proteases virais e da célula hospedeira) para dar origem às proteínas estruturais ("core" e as proteínas do envelope E1 e E2), o polipeptídeo p7 e as proteínas não estruturais (NS2, NS3, NS4A, NS4B, NS5A, NS5B). As proteínas estruturais e o polipeptídio p7 são processados pelo retículo endoplasmático (RE) através de peptidases, enquanto que as proteínas não estruturais são processadas por 2 proteases virais: protease NS2-3 e a protease serina NS3-4A (19). 


\subsection{Estrutura e funções das proteínas do VHC}

\subsubsection{Proteínas estruturais}

As proteínas estruturais do VHC compreendem aos primeiros 809 aminoácidos da poliproteína. A proteína C (ou “core”) constitui o nucleocapsídeo viral (que circunda o genoma do RNA do vírus) e as proteínas E1 e E2 são glicoproteínas que constituem o envelope. A proteína do "core" é uma estrutura $\alpha$-helicoidal, encontrada nas membranas do retículo endoplasmático (RE) e que, na sua superfície possui resíduos de lipídios. Existem evidências de que a interação da proteína do "core" com os resíduos de lipídios pode afetar o metabolismo dos lipídios, contribuindo para o desenvolvimento da esteatose hepática, que ocorre principalmente em pacientes infectados com genótipo 3 (24). Esta proteína tem papel na formação do nucleocapsídeo, na modulação do gene da transcrição, na proliferação celular, morte celular e nos mecanismos de sinalização celular (10).

As proteínas E1 e E2 são glicosiladas e forma um complexo não covalente responsável pela formação do envelope do VHC. Estas duas proteínas têm um papel importante na entrada do VHC na célula (25). Na região E2 do envelope foi identificada uma região altamente variável. Estes aminoácidos podem diferir em mais de $80 \%$ entre os diferentes genótipos do VHC e entre os subtipos do mesmo genótipo (26).

As proteínas estruturais são separadas das não estruturais por uma proteína de membrana p7. Este é um polipeptídio que possui dois segmentos 
trans-membrana conectados por alça citoplasmático. A proteína p7 não está envolvida na replicação do RNA "in vitro", mas conforme demonstrado por Yanagi (1999) (27) é essencial para produzir infecção "in vivo". Estudos mostram que a p7 pode ter um importante papel na maturação e liberação do vírus (28).

\subsubsection{Proteínas não-estruturais}

As proteínas não-estruturais são traduzidas a partir do códon 810 e compreendem várias proteínas (NS2, NS3, NS4A, NS4B, NS5A, NS5B), que contêm diversas atividades enzimáticas (10).

A única função conhecida da proteína NS2 é participar da clivagem proteolítica na junção NS2-NS3. A atividade catalítica reside na metade do terminal C da NS2 e no terço do N-terminal da NS3. NS2 é uma proteinase metal-dependente e sua atividade é estimulada pelo $\mathrm{ZnCl}_{2}(29)$.

NS3-4A é uma proteína multifuncional com função serina protease no um terço do N-terminal e função RNA helicase/NTPase nos dois terços da região C-terminal. Interage diretamente com NS4A, NS4B, NS5B e NS5A dentro do complexo de replicação. Outras interações com componentes celulares estão descritas, como proteínas quinases A e C, p53 e histonas (H2B e H4), mas seu significado não está bem estabelecido. NS4A é um cofator para a protease NS3 (30).

A NS4B é uma proteína de membrana de 27 kDa e que tem papel na alteração da membrana e na formação do complexo de replicação do VHC (31). 
A NS5A é uma fosfoproteína que pode ser encontrada na forma basal de $56 \mathrm{kDa}$ e na forma hiperfosforilada de $58 \mathrm{kDa}$. Dados recentes mostram que a fosforilação modula a eficiência da replicação do RNA do VHC (14). Há evidências da relação entre as seqüências do vírus e persistência e resistência ao tratamento demonstrado na região NS5A que interage com a PKR uma quinase ativada por RNA de fita dupla (dsRNA). Em geral, dsRNAs são encontrados apenas em células infectadas por vírus, na forma de intermediários replicativos. O papel da proteína NS5A do VHC na modulação da resposta ao interferon tem sido objeto de diversos estudos. Em 1995, Enomoto (32) e colaboradores identificaram em pacientes japoneses infectados com genótipo $1 \mathrm{~b}$ e não respondedores ao interferon, uma sequência conservada de 40 aminoácidos na região carboxi-terminal da proteína NS5A. Por outro lado, os isolados de pacientes que responderam à terapia apresentaram mutações nesta região, que passou a ser designada como região determinante da sensibilidade ao interferon (ISDR) (32). Assim como a proteína E2, a NS5A interage com a PKR tornando-a inativa (33), o que poderia explicar a resistência do VHC à terapia com interferon.

A replicação do VHC ocorre através da fita de RNA de polaridade positiva que serve de molde para a síntese da fita de RNA de polaridade negativa e assim sucessivamente, sendo que a enzima chave para esse processo é a NS5B RdRp (RNA polimerase RNA dependente). Com base nas estratégias de outros vírus RNA de polaridade positiva, a replicação do VHC provavelmente envolve o mecanismo "de novo", isto é sem a necessidade de iniciadores através de um complexo de replicação envolvendo diferentes 
proteínas. A proteína NS5B tem uma estrutura polimerase típica denominada de mão direita, com sítios catalíticos na base da palma circundada por diferentes domínios de dedos e polegar (10). Vários estudos mostram que esta enzima pode se tornar o principal alvo para intervenção antiviral (19).

\subsection{Diversidade genética do VHC}

A variabilidade do VHC existe em diferentes níveis. Há evidências de que o vírus VHC sofre processo adaptativo demonstrado através da rápida evolução da região hipervariável da glicoproteína do envelope E2 para prevenir o reconhecimento dos anticorpos induzidos pela infecção. Por outro lado, a teoria neutral mostra que a maioria das mudanças nas seqüências entre as espécies não afetam o fenótipo (34). Esta teoria explica grande parte da diversidade genética observada em populações geográfica e epidemiologicamente diferentes do VHC (35). Existe uma divergência de 5-8\% entre variantes de cepas dos genótipos 1a, 1b e 3a em infecções não correlacionadas. Essa diversidade também pode ser observada dentro de uma infecção no mesmo indivíduo, denominada de "quasiespécies" e podem diferir em torno de 10\% dentro de uma mesma população (36). Isto se deve também porque o RNA polimerase não tem capacidade de revisão ou seja de correção dos nucleotídeos ao sintetizar a fita de RNA. Somado a isso, o VHC possui uma alta taxa de $10^{12}$ partículas virais por dia, na replicação dos vírus (37). Por consequência, origina-se uma população com alta variabilidade genética e com muitas mutações que podem diferir em diferentes combinações dentro de uma população. As "quasiespécies" são importantes na história natural da 
infecção, pois esta diversidade provavelmente está relacionada ao mecanismo de escape do vírus ao sistema imune do hospedeiro (38).

A recombinação entre os genótipos é uma descoberta recente e com implicações na classificação do VHC. Essa recombinação pode acontecer pela própria história natural da infecção, que é caracterizada por múltiplas exposições como o compartilhamento de agulhas entre os usuários de drogas e contaminação com produtos de sangue como o fator VIII de plasmas contaminados principalmente entre os pacientes com hemofilia e talassemia. A infecção pelo VHC não protege contra uma nova infecção em experimentos com chimpanzés(39). Diferentes estudos descrevem cepas recombinantes $(40,41)(42)(43)$. A variabilidade genética preexistente, combinada com uma alta taxa de erro na replicação do VHC num paciente com infecção crônica permite uma grande variação genética que pode se adaptar a novas pressões seletivas como a resposta imune e o tratamento antiviral (35).

\subsection{Classificação do VHC}

A classificação do VHC, redefinida e simplificada em 1998, é baseado na topologia de árvores obtidas através de análises filogenéticas entre diferentes variantes virais. As variantes do VHC podem ser classificadas dentro de seis clados ou genótipos. Os genótipos podem diferir entre si, de 31\% a 33\% nas seqüências dos nucleotídeos e são denominados através de algarismos arábicos de 1 a 6 (44). Os subtipos podem diferir de 20 a 25\% e são denominados por letra em ordem alfabética correspondendo às seqüências correlatas dentro 
de um clado. A nova reclassificação agrupou os genótipos 7, 8, 9 e 11 como genótipo 6 e o genótipo 10 como genótipo 3 (45).

\subsection{Distribuição geográfica dos genótipos do VHC}

Os seis principais genótipos do VHC, cada um compreendendo múltiplos subtipos, foram identificados em diferentes áreas geográficas do mundo. Há uma associação muito forte entre genótipos e região geográfica (Figura 3).

Os genótipos 1, 2 e 3 são igualmente prevalentes em várias regiões do globo, embora a prevalência relativa varie de um local para outro (46). As variantes mais comuns dos genótipos encontrados em países do ocidente são classificadas como 1a e 1b dentro do genótipo 1, 2a, $2 \mathrm{~b}$ e $2 \mathrm{c}$ dentro do genótipo 2, além do genótipo 3a (46). Estas variantes começaram a ser amplamente distribuídos nos últimos 50-70 anos como resultado da transmissão através de transfusão sangüínea, procedimentos cirúrgicos e compartilhamento de agulhas entre usuários de drogas e demonstra a rota de transmissão nestes países (36). O genótipo 3a é prevalente em usuários de drogas nos Estados Unidos e Europa (47). Os subtipos 1a e 1b são os mais comuns nos Estados Unidos e na Europa (46) (48), enquanto que no Japão o subtipo 1b é responsável por mais de $73 \%$ dos casos de infecção pelo VHC (49). Em relação ao genótipo 2, os subtipos 2a e 2b são comuns na América do Norte, Europa e Japão enquanto o subtipo 2c é comumente encontrado no norte da Itália (36). Diferentes perfis de diversidade genética são observados em partes do continente africano e no sudeste da Ásia. Infecções no oeste da África são causadas predominantemente pelo genótipo 2 (50). Entretanto, na 
África Central como na República Democrática do Congo e Gabão, as infecções são causadas por genótipos 1 e 4 (51). O genótipo 4 é mais comum no norte e no meio leste da África, o genótipo 5 é mais comum no sul da África, enquanto que o genótipo 6 é encontrado no sudeste da Ásia. Em ambas as regiões ocorrem uma alta diversidade de subtipos. Por exemplo, foram encontrados 23 indivíduos positivos com RNA do VHC em doadores de banco de sangue, todos foram classificados como genótipo 2, mas cada um deles correspondia a diferentes subtipos não descritos (50). Do mesmo modo, ocorre similar diversidade nos genótipos 3 e 6 encontrados sudeste da Ásia (52). Estes dados demonstram provavelmente que a infecção pelo VHC no homem existe há um longo período nessas populações.

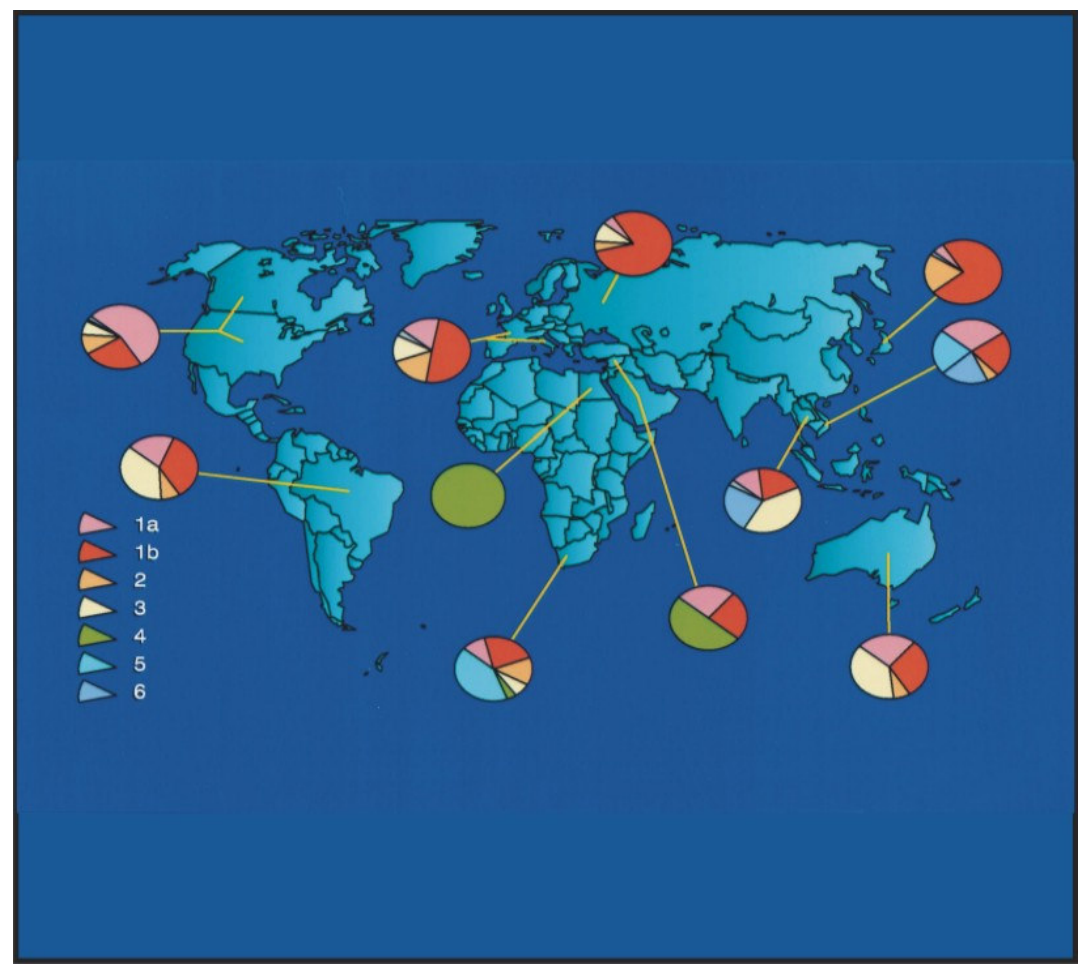

Figura 3 - Distribuição geográfica dos diferentes tipos e subtipos ao redor do mundo

FONTE: Zein (2000) adaptado por Nakatani 
No Brasil, há uma prevalência maior do genótipo 1 (Figura 4) que varia de 51,7 a $74,1 \%$ alcançando as maiores taxas na região norte, $4,6 \%$ para o genótipo 2 e 30,6\% para o genótipo 3 (53) (54), enquanto que na região sul há um equilíbrio entre os genótipos 1 e 3 com uma prevalência de 53,9\% para o genótipo 1 e 40,7\% do genótipo 3 (55). Outro estudo mostra a prevalência do genótipo 1 em 92,4\% e do genótipo 3 de 7,6\% em pacientes hemodialisados na região central do Brasil mais precisamente no Estado de Goiás (56). Enquanto que os genótipos 4 e 5 são raramente descritos (57).

No Paraná ocorre uma prevalência de em torno de $53 \%$ para o genótipo 1, 41\% para o genótipo 3 e 4,6\% para o genótipo 2 (58).

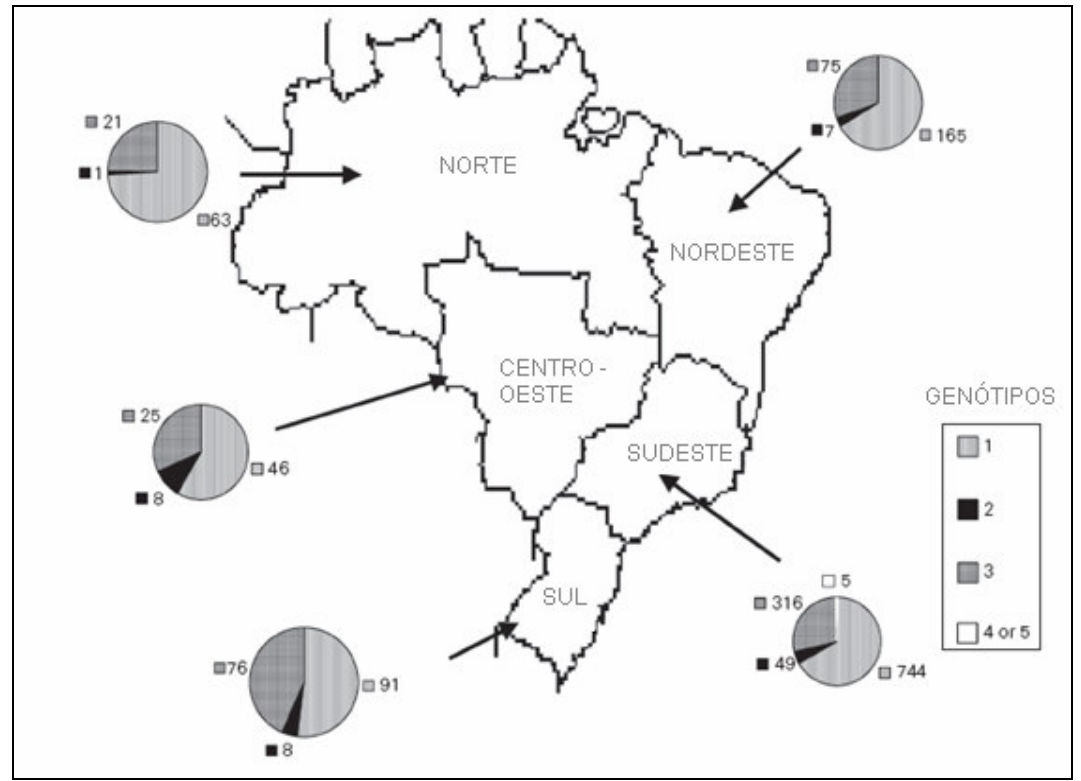

Figura 4 - Distribuição dos genótipos do VHC em diferentes regiões do Brasil

FONTE: Campiotto et al. (2005) 


\subsection{Relevância clínica}

\subsubsection{Correlação entre genótipos e doenças hepáticas}

Os mecanismos pelo qual o vírus da hepatite $\mathrm{C}$ causa danos ao fígado de modo crônico e progressivo são desconhecidos. Fatores outros além do próprio vírus estão implicados. A esteatose hepática é um dos achados freqüentes em biópsias de pacientes com hepatite $C$ crônica, variando entre 30 a $65 \%$ e em alguns de modo severo e extenso. A esteatose pode resultar de fatores metabólicos e fatores virais (59).

Os fatores metabólicos estão relacionados ao consumo de álcool, aumento do índice de massa corpórea, diabete do tipo II e hiperlipidemia. A esteatose viral pode estar relacionada com os efeitos citopáticos do VHC, particularmente do genótipo 3 (60). Em um estudo com 1428 pacientes com infecção crônica pelo VHC, foi observada esteatose hepática em $65 \%$ dos pacientes sendo que destes, $83 \%$ pertenciam ao genótipo 3, em comparação com $62 \%$ que não eram genótipo $3(p<0,001)(61)$. A esteatose viral é atribuída a efeitos diretos de algumas proteínas virais no metabolismo dos lipídios nos hepatócitos. Algumas destas proteínas são as proteínas do core e NS5A, que se co-localizam com estruturas globulares dos lipídios, podendo também interferir no transporte dos triglicerídios (62). Entretanto, os efeitos da esteatose hepática são controversos entre os diferentes estudos em relação à falha no tratamento antiviral (63) (61). 


\subsubsection{Correlação entre genótipos e transplante hepático}

A reinfecção após transplante hepático em pacientes com hepatite $C$ crônica ocorre em $95 \%$ dos pacientes e o desenvolvimento de cirrose hepática após 5-7 anos ocorre em 8 a 30\% (64). Os fatores que determinam o curso da hepatite C pós-transplante são vários, incluindo os virais, os dos hospedeiros e diferentes parâmetros dos doadores.

Em relação ao vírus, o genótipo, a carga viral e a presença de "quasiespécies" são analisadas. Vários trabalhos relatam um prognóstico pior para pacientes infectados com genótipo 1b (46). Outros relatam um aumento nos mecanismos da apoptose em pacientes infectados com este mesmo genótipo (65).

\subsubsection{Tratamento em relação aos genótipos}

A genotipagem é um das principais ferramentas no prognóstico e manejo dos pacientes quanto ao tempo de tratamento. Os resultados da detecção do RNA viral e da genotipagem são utilizados no algoritmo de tratamento dos pacientes infectados pelo VHC (66). Indicações para o tratamento dos pacientes com infecção crônica pelo VHC incluem detecção do RNA viral pelas técnicas moleculares, aumento das aminotransferases hepáticas e evidências histológicas de fibrose hepática e inflamação moderada. "Score" da classificação Metavir $A \geq 2$ e ou $F \geq 2$ são indicações para a terapia. A eficácia da terapia é avaliada pela resposta virológica sustentada (RVS) isto 
é, níveis indetectáveis do RNA viral (abaixo do limite de detecção: $50 \mathrm{Ul} / \mathrm{ml}$ ou menor) no sangue periférico após o término da mesma.

\section{a) Genótipo 1}

O tratamento da infecção crônica pelo VHC, quando realizada com interferon monoterapia, tem uma resposta sustentada em somente 10 a $20 \%$ dos casos. Quando em associação com ribavirina, a taxa de resposta sustentada é em torno de 40\% (67). Atualmente, o consenso é a utilização do interferon peguilado mais ribavirina em doses diárias ocorrendo uma resposta sustentada em aproximadamente $54 \%$ dos pacientes infectados com o genótipo 1 (63). Estes requerem um tempo de tratamento de 48 semanas (66). A monitoração da diminuição da carga viral é importante para evitar tratar pacientes que não têm prognóstico de RVS. Para isto, é necessário fazer a quantificação do RNA do VHC na $12 .^{\text {a }}$ semana e comparar com a carga viral realizada no início do tratamento. O tratamento não deve ser continuado se não houver uma queda de 2 log ou mais. Se o RNA for indetectável na semana 12 é recomendável realizar a detecção do RNA por uma técnica sensível na semana 24 (66). Se o RNA for indetectável, o tratamento deve ser continuado até a semana 48 com uma larga chance de atingir RVS (68). Resposta rápida sustentada é definida como pacientes que apresentam RNA indetectável na $4 .^{a}$ semana de terapia. Estudos recentes predizem que a 4. ${ }^{a}$ semana tem um alto valor prognóstico para a RVS (69). Por outro lado, se o RNA for detectável na $24 .^{a}$ semana a chance de RVS é quase nula e o tratamento deverá se interrompido ou continuado somente em pacientes com prognóstico severo (70). Quando o tratamento é realizado até $48{ }^{a}$ 
semana a RVS deve ser verificado com um teste sensível de detecção do RNA com limite de detecção de $50 \mathrm{UI} / \mathrm{ml}$ ou menor. Novo teste deve ser realizado após 24 semanas após o final do tratamento para verificar RVS (71).

b) Genótipos 2 e 3

Pacientes infectados com genótipos 2 e 3 têm um prognóstico de $70 \%$ a $80 \%$ de RVS com baixa dose de ribavirina e com 24 semanas de tratamento (72) (73) (74). Porém, certas condições apresentadas pelo paciente como fibrose extensa, idade avançada e sexo masculino necessitam de 48 semanas de tratamento para atingir RVS (75).

Não se recomenda a monitoração da carga viral nos pacientes com infecção pelos genótipos 2 e 3 porque a maioria apresentará RNA do VHC negativo na $12 .^{\text {a }}$ semana. A detecção do RNA do VHC deverá ser realizada ao final do tratamento e 24 semanas após o tratamento para determinar RVS (66).

\section{c) Genótipos 4, 5 e 6}

Não existe ainda um "trial" clinico com números suficiente de pacientes para um protocolo de tratamento para estes indivíduos. É recomendado que se utilize o mesmo esquema de tratamento do genótipo 1, isto é, peg-interferon com altas doses de ribavirina (1000-1200 mg por dia de acordo com o peso do pacientes, maior ou menor que $75 \mathrm{~kg}$ ). O tempo de tratamento deve ser de 48 semanas. A RVS deve ser verificada através da detecção do RNA viral no final da terapia e após 24 semanas (66). 
d) Tratamento no Brasil

No Brasil, o protocolo de tratamento para o VHC, segundo a portaria 34, do Ministério da Saúde, de 28 de setembro de 2007 publicada em 09/10/2007 (2) preconiza que para os genótipos 2 e 3 o tratamento deve ser realizado com interferon mais ribavirina por 24 semanas e para o genótipo 1 o tratamento deve ser realizado com peg-interferon mais ribavirina, por 48 semanas.

Pacientes não respondedores, de qualquer genótipo, pacientes que apresentaram recidiva viral, pacientes com coinfecção VHC/HIV têm direito ao retratamento com peg-interferon.

\subsection{Identificação dos genótipos do VHC}

\subsubsection{Regiões do VHC para genotipagem}

A região 5'UTR é a região de escolha para a detecção qualitativa e quantitativa do RNA do VHC pela alta conservação da região permitindo a melhora da sensibilidade. Por esta razão é a região mais utilizada para a genotipagem do VHC na maioria dos laboratórios clínicos. Entretanto, devido a sua alta conservação a região 5'UTR não é adequado para discriminar o genótipo 6 do genótipo 1 e os subtipos para os genótipos 1,2, 3, 4 e 6 . A única possível exceção é o genótipo 5 , o qual não tem relatos de outros subtipos a não ser o $5 a$. Os variantes dos genótipos 6 outros que não $6 a$ e 6b mostram similaridades nas seqüências com o genótipo 1 e como 
consequência não pode ser diferenciado e não recomendado o uso de métodos que utilizam a região 5'UTR nos países do sudeste da Ásia onde ocorre uma prevalência maior do genótipo $6(76,77)$. Em relação aos subtipos a região 5'UTR não consegue distinguir os subtipos $2 \mathrm{a}$ do $2 \mathrm{c}(78)$. Além disso a identificação dos subtipos $1 \mathrm{a}$ do $1 \mathrm{~b}$ também é prejudicado pelo fato que o fragmento analisado difere somente em um nucleotídeo na posição 99 (79). Outro exemplo é o resíduo na posição 243 da região 5'UTR considerado representativo do subtipo $1 \mathrm{~b}$, porém é encontrado com relativa proporção no subtipo 1a (80-82). Dessa forma é fundamental a escolha de uma região que apresente um polimorfismo maior dentro do genoma e que permita diiferenciar os diferentes genótipos e os seus subtipos de forma mais acurada. As regiões mais estudadas com essa finalidade são as regiões do core, do envelope E1 e a região NS5B (83). A representação esquemática do genoma do VHC conforme figura 5 mostra a proteínas estruturais e não estruturais. O diagrama demonstra a diversidade das seqüências entre os diferentes genótipos dentro de uma região de 150 pb ao longo do genoma. Esta análise revela que as regiões mais conservadas são a da 5'UTR e do core, e as regiões que possuem maior variabilidade estão na regiões do envelope e NS5A. A região NS5B apresenta uma variabilidade mediana o que faz dela a região ideal para a diferenciação entre os diferentes genótipos e seus subtipos (35). 


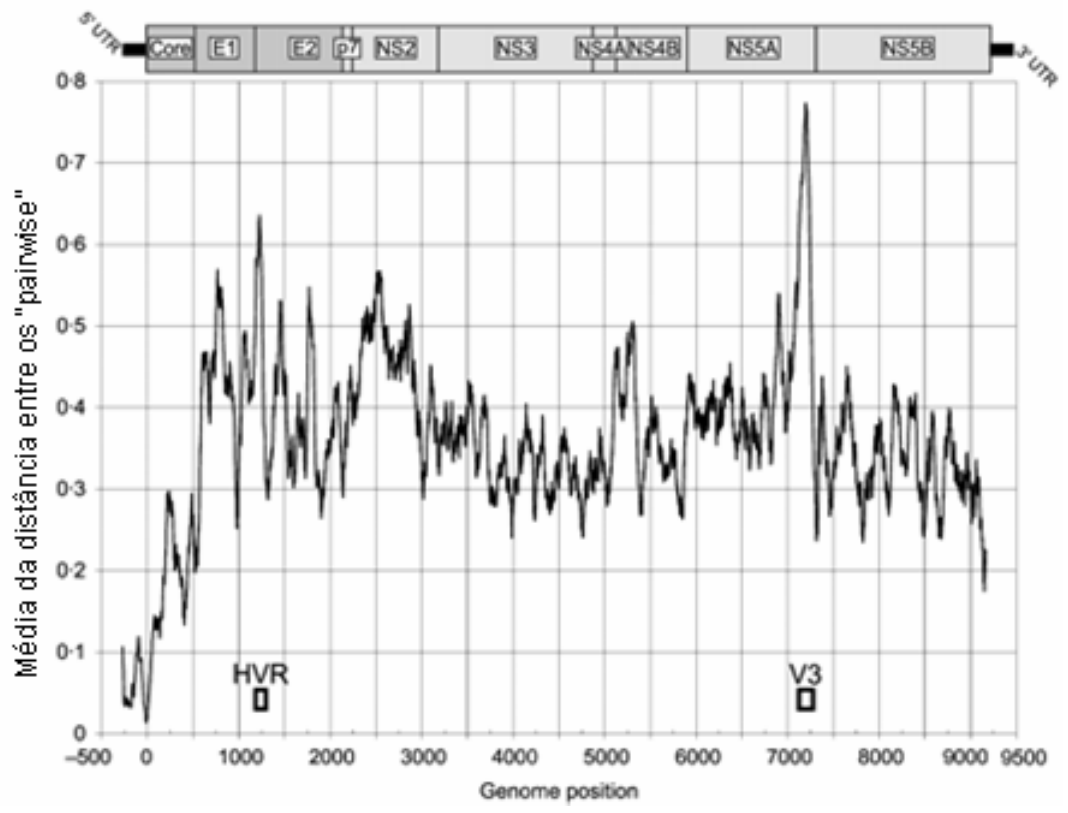

Figura 5 - Representação esquemática do genoma do VHC, com as proteínas estruturais e não estruturais.

FONTE: Simmonds, P (2004)

\subsubsection{Métodos de genotipagem não comerciais}

a) Seqüênciamento de regiões específicas do VHC

O padrão-ouro para a genotipagem do VHC é a RT-PCR (transcrição reversa - reação em cadeia da polimerase), seguida do seqüênciamento dos nucleotídeos de regiões como NS5B, core e E1 e comparação das seqüências obtidas com seqüências de consenso provenientes de banco de dados como o GenBank ou "los Alamos hepatitis C" (Figura 6) (38). 
Vários laboratórios utilizam o seqüênciamento para determinação dos genótipos do VHC. Além de ser o padrão ouro para a genotipagem, esse método fornece de modo mais acurado os diferentes subtipos que podem ser utilizados nos estudos epidemiológicos (38). Entretanto, existem diferentes desvantagens como a exigência de mão-de-obra qualificada, equipamento de alto custo, além da necessidade de utilizar diferentes protocolos até chegar ao passo final do seqüênciamento consumindo um tempo longo, além do que, o seqüênciamento não consegue identificar infecção mista como em outros métodos baseados em hibridização (84). Possui uma sensibilidade média que pode variar dependendo dos "primers" empregados, e da região do genoma utilizada (85).

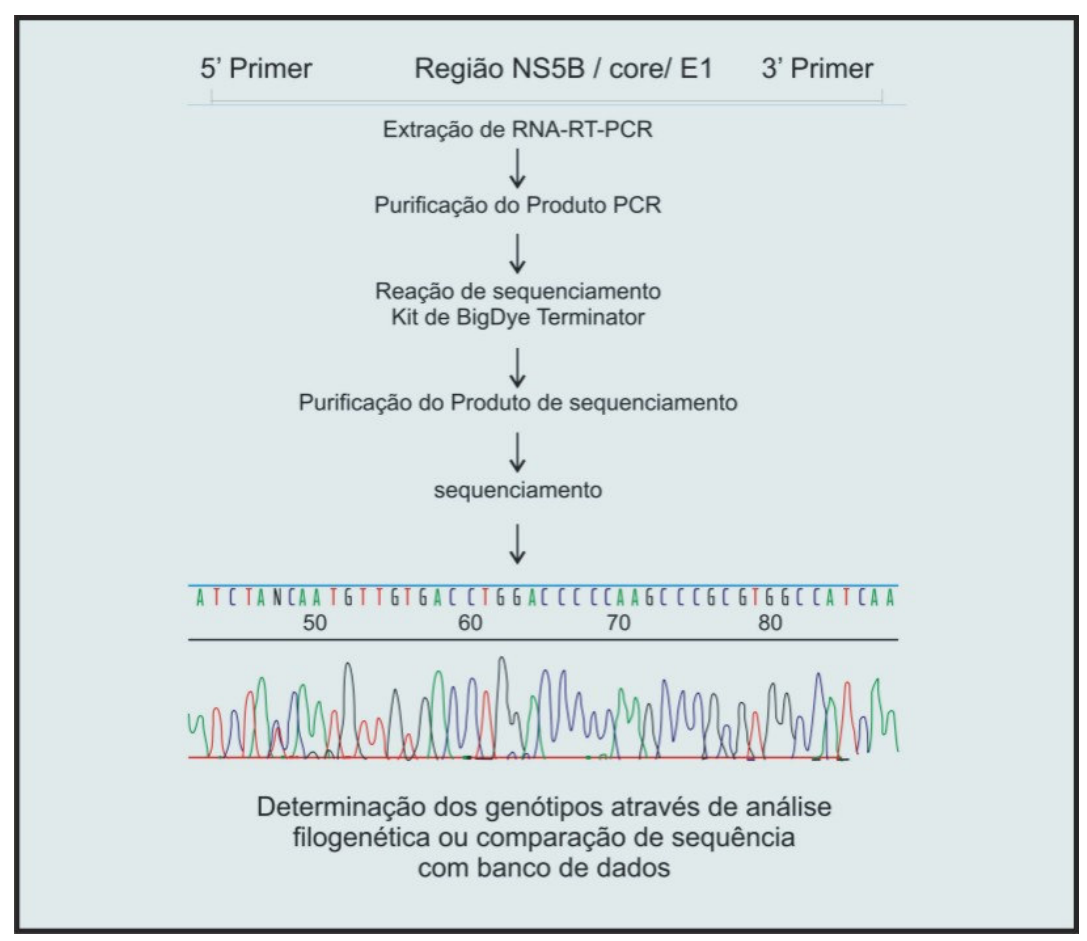

Figura 6 - Esquema dos diferentes passos necessários para a realização do seqüenciamento

FONTE: Weck (2005) 
b) PCR "primers"- específico

Vários grupos desenvolveram ensaios de RT-PCR tipos específicos da região do core e do NS5B do VHC Nestes ensaios, "primers" específicos para diferentes subtipos foram desenhados para gerar produtos de PCR de diferentes tamanhos e a determinação do genótipo se faz através da eletroforese e posterior visualização dos tamanhos da banda. Apesar de o método ser mais fácil e rápido do que o seqüênciamento o mesmo não possui acurácia. Isto se deve ao fato de utilizar um único par de "primers" para cada subtipo e a variabilidade genômica presente nos sítios de ligação destas seqüências pode ter como consequência uma falha na amplificação ou uma identificação incorreta (84). O primeiro trabalho foi descrito por Okamoto (1992) (86), neste método havia um problema na diferenciação dos genótipos 1a e 1b, porque o "primer" desenhado tinha uma amplificação cruzada com algumas cepas do genótipo 1a, ou as amostras eram classificadas como infecções mistas $1 \mathrm{a} / 1 \mathrm{~b}$. Outros métodos foram desenvolvidos para uma identificação correta do genótipo 1, mas ainda continuaram a apresentar problemas com a identificação de outros genótipos (87). Em um estudo recente comparando os métodos de Okamoto e Ohno com outros métodos de genotipagem e como padrão ouro o seqüênciamento da região do core, verificou-se que o método de Ohno identificava bem os genótipos 3 e 4. Entretanto, os genótipos 1 e 2 não tiveram o mesmo desempenho. $\mathrm{O}$ método de Okamoto teve um desempenho inadequado para todos os genótipos além de identificação de mais de um genótipo em grande parte das amostras, demonstrando que os desenhos dos "primers" não foram adequados (88). 
c) Ensaios de polimorfismos de tamanho de fragmento de restrição

Os ensaios com polimorfismo de tamanho de fragmento de restrição (RFLP) possibilitam utilizar diferentes enzimas de restrição para diferentes genótipos que contem sítios específicos. Os sítios específicos desses produtos da RT-PCR são submetidos à digestão por diferentes enzimas de restrição. A determinação do genótipo se dá pelo perfil dos tamanhos dos fragmentos visualizados após eletroforese. A interpretação dessa visualização algumas vezes pode ser difícil. Estes ensaios estão descritos na região 5'UTR, "core" e região NS5B (89) (90). A acurácia da PCR-RFLP varia de um modo amplo. Em geral, a PCR-RFLP da região 5'UTR identifica bem os principais genótipos do VHC. Entretanto, estudos comparando PCR-RFLP com outros métodos baseado na região 5'UTR mostrou discrepâncias para tipo e subtipos (91). Uma vez que algumas variantes do genótipo 6 possuem seqüências like-1 na região 5'UTR outro método baseado na região do core foi descrito para diferenciar os genótipos 1 e 6 (77). Por outro lado, o método baseado na região do core não conseguiu distinguir com acurácia outros genótipos além do 1 e 6 sendo preciso utilizá-lo em conjunto com outro método de genotipagem (76).

Os métodos de PCR-RFLP são trabalhosos e não possuem acurácia suficiente para diferenciar os genótipos. Atualmente, foram substituídos em grande parte pelos métodos comerciais que não requerem eletroforese. Porém este método foi um dos primeiros métodos para genotipagem do VHC baseados nas seqüências e foi utilizado em vários estudos, incluindo um dos maiores estudos epidemiológicos realizado para verificar a distribuição geográfica dos genótipos no mundo (92). 
d) Genotipagem do VHC por PCR em tempo real

O desenvolvimento da reação em cadeia da polimerase (PCR), descrito por Kary Mulis e colaboradores (1987) (93), permitiu que essencialmente qualquer sequência de ácidos nucléicos presente numa amostra biológica pudesse ser amplificada num processo cíclico para gerar um grande número de cópias idênticas, que podem ser imediatamente analisadas. Esse processo tornou possível, por exemplo, manipular o DNA para clonagem, ensaios de engenharia genética e seqüênciamento de genomas (94). Entretanto, como técnica analítica, o método de PCR original apresenta algumas limitações. Essa limitação foi resolvida com o desenvolvimento da PCR em tempo real por Higuchi e colaboradores (1992) (95). A técnica foi desenvolvida através de um equipamento que possui um termociclador, um sistema ótico e uma câmera CCD ("Charged Coupled Device"). De maneira geral, todos os equipamentos de PCR em tempo real possuem uma fonte de emissão de luz, que pode ser uma lâmpada halógena ou um feixe de laser. À frente da fonte de luz estão colocados os filtros de excitação, que selecionam o comprimento de onda específico para a excitação de cada fluoróforo presente na reação. A luz é então direcionada para a placa de amostras através de um conjunto de espelhos dicróicos. Os corantes presentes na amostra são excitados e emitem fluorescência, que é direcionada pelos espelhos para o filtro de emissão. Esse filtro seleciona a luz emitida nos comprimentos de onda específicos de cada corante presente na reação. A luz selecionada é direcionada para a câmera CCD, que converte o sinal luminoso em sinal eletrônico, que é utilizado pelo software gerenciador do equipamento para o traçado gráfico da reação (95). 
$\mathrm{Na}$ PCR em tempo real, a quantidade de produto formado é monitorada durante o curso da reação de amplificação por monitoramento da fluorescência dos corantes ou sondas introduzidos na reação, que é proporcional à quantidade de produto formado, enquanto o número de ciclos necessário para obter uma quantidade determinada de moléculas de DNA é registrado. Assumindo uma determinada eficiência na amplificação, que normalmente é próxima à duplicação do número moléculas por ciclo de amplificação, é possível calcular o número de moléculas de DNA da sequência amplificada presentes inicialmente na amostra. Com a utilização de químicas de detecção altamente eficientes, instrumentos sensíveis e ensaios otimizados, o número de moléculas de DNA alvo na amostra pode ser determinado com acurácia e sensibilidade sem precedentes, suficientes para detectar uma única molécula de DNA (96).

Além dos componentes tradicionais utilizados na PCR convencional - como tampão Tris- $\mathrm{HCl}, \mathrm{MgCl}_{2}$, dNTP, iniciadores, Taq DNA polimerase - a PCR em tempo real necessita de um sistema de monitoramento. Esse sistema é composto por corantes fluorescentes que se ligam ao produto formado e reportam sua presença a partir da emissão de fluorescência. Durante os ciclos iniciais o sinal fluorescente é fraco e não pode ser distinguido da fluorescência de fundo ("background"). À medida que o produto de PCR se acumula, o sinal fluorescente é percebido, aumentando exponencialmente durante os primeiros ciclos da reação. Em seguida, o nível de sinal é saturado. Essa saturação ocorre em função do consumo de alguns componentes críticos para a reação; ou seja, iniciadores, sistema de detecção ou dNTP. Outro componente limitante é o número de moléculas de 
polimerase, cujo decréscimo faz com que a amplificação exponencial seja convertida em amplificação linear (96) (94).

É importante notar que num experimento de PCR em tempo real todas as curvas-resposta são saturadas no mesmo nível de fluorescência. Portanto, a quantificação em ponto final, como ocorre na PCR convencional, não é informativa quanto à quantidade inicial de moléculas-alvo presente na amostra e permite apenas resultados qualitativos. Por outro lado, as curvasresposta da PCR em tempo real são monitoradas durante a fase exponencial da reação, o que reflete a diferença na quantidade inicial de moléculas de DNA (94). Essa diferença é quantificada pela comparação do número de ciclos de amplificação necessários para que curva-resposta de uma determinada amostra atinja um determinado nível de sinal fluorescente ("threshold"). O número de ciclos necessários para atingir o "threshold" é chamado $\mathrm{Ct}$ (Cycle threshold), que é o dado utilizado para a quantificação da amostra. É esperado que as curvas de amplificação sejam paralelas durante a fase exponencial da reação, de modo que o ajuste do "threshold" não seja crítico para a quantificação. Assim, a seleção do "threshold" é parcialmente arbitrária e isso não afeta significativamente as diferenças entre os Ct das amostras (96).

Em um sistema de PCR cuja eficiência é 100\%, a quantidade de produto formado segue a lógica de uma progressão geométrica tipo $2^{n}$, em que $n$ é o número de ciclos de amplificação. Num sistema imperfeito, a eficiência do sistema pode ser estimada por uma curva-padrão baseada em diluições de um padrão. Os valores de Ct dos padrões diluídos são plotados 
contra o logaritmo da concentração inicial da amostra $\left(N_{0}\right)$, número de cópias ou fator de diluição, o que pode ser representado pela equação:

$$
\mathrm{Ct}=k \times \log \left(N_{0}\right)+\mathrm{Ct}(1)
$$

A eficiência é calculada através do slope $(k)$ como:

$$
E=10^{-\frac{1}{k}}-1
$$

O intercepto da curva-padrão [Ct(1)] corresponde ao logaritmo do número de moléculas do "amplicon" presentes no "threshold".

O sistema de PCR em tempo real utiliza exclusivamente fluorescência como método de detecção. Estão disponíveis para uso como "reporter" tanto sondas específicas quanto corantes não-específicos. No trabalho inicial de Higuchi e colaboradores, foi utilizado como corante o brometo de etídio, que se torna fluorescente a partir da intercalação no DNA. Intercaladores clássicos, entretanto, interferem com a reação da polimerase e atualmente corantes tipo cianinas assimétricas como SYBR Green I e BOXTO têm-se tornado populares (97) (98). Esses corantes não apresentam fluorescência quando estão livres em solução, mas tornam-se fluorescentes quando se ligam ao DNA, presumivelmente na fenda menor da hélice de DNA. Na PCR, a fluorescência desses corantes aumenta proporcionalmente à quantidade de produto duplafita formado. Apesar de serem apropriados para PCR em tempo real quantitativa (qRT-PCR), esses corantes geram sinal fluorescente na presença de qualquer DNA dupla-fita, incluindo produtos inespecíficos e "primer-dimer" sendo, portanto, considerados "reporter" não-específicos na reação de PCR em tempo real (94). Formatos de detecção baseados na hibridização específica de uma ou duas 
sondas marcadas com fluoróforos à sequência-alvo específica durante a amplificação são os mais comumente utilizados. Dependendo da química utilizada, diferentes tipos de sondas fluorogênicas podem ser descritas.

A maioria dos ensaios descritos para a detecção de DNA ou RNA é baseada na utilização de sondas de hidrólise (54). Sondas de hidrólise são comumente conhecidas como sondas $\operatorname{TaqMan}^{\circledR}$ (Applied Biosystems, Foster, CA, USA) ou sondas 5' nuclease. Essas sondas são duplamente marcadas, contendo um fluoróforo "repórter", como FAM ou VIC, covalentemente ligado à extremidade 5'; e um fluoróforo "quencher", como TAMRA, covalentemente ligado à extremidade 3'. Quando a molécula "reporter" é estimulada por uma fonte de luz a emitir fluorescência, essa energia é transferida para o "quencher", o que suprime a emissão de fluorescência pelo "reporter". Esse princípio físico é conhecido como transferência da energia ressonante da fluorescência FRET (99). Essa transferência de energia se dá eficientemente somente em distâncias muito curtas e diminui rapidamente quando o "reporter" e o "quencher" são separados. Durante a PCR, quando a Taq DNA polimerase estende os iniciadores, a sonda hibridizada é clivada devido à atividade $5^{\prime}$ exonuclease da enzima e as moléculas "reporter" e "quencher" são separadas. Isso extingue o FRET e faz com que a fluorescência do "reporter" deixe de ser captada pelo "quencher" e passe a ser detectada pelo sistema ótico do equipamento de PCR em tempo real (Figura 7). Existe uma correlação linear entre os números de moléculas "reporter" liberadas e o número de "amplicons" formados durante cada ciclo da PCR. Essa correlação serve como base para o cálculo do número de cópias inicial da sequência-alvo (94). Atualmente, as 
sondas $\operatorname{TaqMan}^{\circledR}$ são marcadas com moléculas "quencher" nãofluorescentes, como "Minor Groove Binder" $\left(\mathrm{MGB}^{\mathrm{TM}}\right)$. Sondas TaqMan ${ }^{\circledR} \mathrm{MGB}^{\mathrm{TM}}$ são oligonucleotídeos curtos caracterizados pela marcação com moléculas ligantes da fenda menor do DNA na extremidade 3' ou, menos freqüentemente, na extremidade 5' (100). Essa modificação química aumenta a temperatura de "melting" da sonda hibridizada e sua afinidade pelo DNA, facilitando a ligação específica à sequência-alvo através da fenda menor da hélice do DNA (96). Além disso, essas sondas contêm um "quencher" que não emite fluorescência, liberando um dos canais de fluorescência do equipamento. Esse melhoramento técnico elimina eventuais sobreposições espectrais com a fluorescência do "reporter", o que leva à maior acurácia na captação do sinal específico do "reporter" e permite trabalhar com mais fluorescentes simultaneamente (94).

As principais vantagens da utilização de sondas $\operatorname{TaqMan}^{\circledR}$ são a facilidade para o desenho das sondas e poucas restrições quanto à seleção das seqüências-alvo. A utilização de sondas fluorogênicas específicas confere não somente maior especificidade na deteç̧ão da sequência-alvo, mas também aumenta a sensibilidade da detecção, comparável àquela obtida em ensaios de nested-PCR ou Southern Blot. Outro benefício dos sistemas baseados em sondas de detecção é a possibilidade de combinar duas ou mais sondas com diferentes marcações fluorescentes em uma única reação de PCR (multiplex PCR). Entretanto, é necessário que os produtos de PCR gerados sejam pequenos (80 a $130 \mathrm{pb}$ ) para obter eficiência máxima no processo de amplificação. Além disso, a temperatura necessária para a atividade $5^{\prime}$ 
exonuclease da Taq DNA polimerase $\left(60^{\circ} \mathrm{C}\right)$ é sub-ótima para a processividade da enzima e pode afetar a eficiência da reação de amplificação (101).

Outros sistemas de detecção freqüentemente utilizados em PCR em tempo real são sondas de hibridização ou "HybProbes" (102), "molecular beacons" (103), "scorpion primers" (104) e "LUX primers" (105).

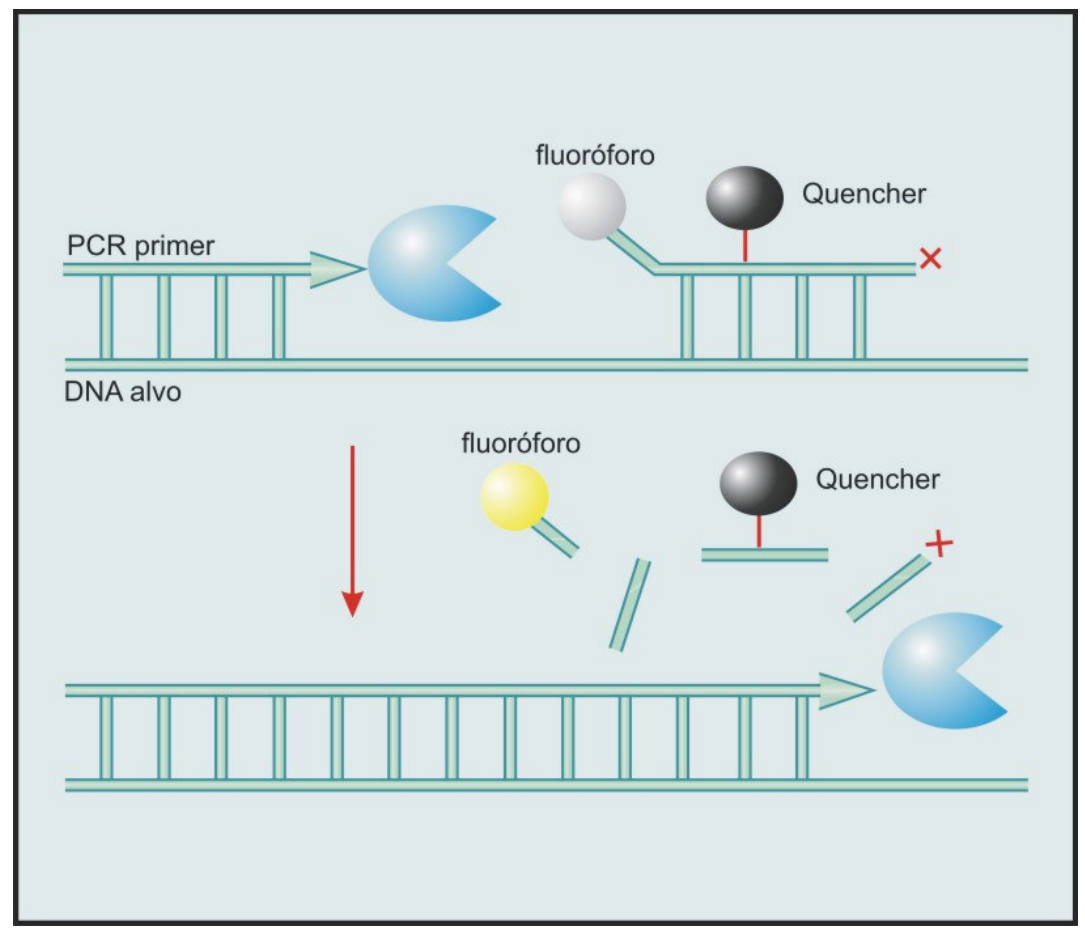

Figura 7 - Ilustração do mecanismo da plataforma TaqMan que através da atividade exonucléasica da Taq polimerase quebra a sonda separando a sonda "reporter do "quencher" e a fluorescência emitida pelo "reporter" ser captada pelo sistema ótico

Existem poucos trabalhos utilizando PCR em tempo real para a genotipagem do VHC. Pela plataforma TaqMan, Moghaddam (2006) (106), descreve a determinação dos genótipos 1, 2 e 3a em 37 pacientes da Noruega. Houve uma correlação de 100\% com seqüênciamento da região 5'UTR e LiPA. Outro estudo mostra 158 amostras que foram analisadas por seqüênciamento 
para os genótipos 1, 2, 3 e 4 através de dois painéis. $O$ primeiro painel contém duas sondas para o genótipo 1 e com duas sondas para identificação dos genótipos 2 e 3 . O segundo painel contém duas sondas para a confirmação dos genótipos 2 e 3 e uma sonda para identificação do genótipo 4. Mostrou uma correlação de 99\% (genótipo 1), 94\% (genótipo 2), 91\% (genótipo 3) e 100\% (genótipo 4) (107). Do mesmo modo, outro artigo mostra que a genotipagem através da PCR em tempo real pela plataforma TaqMan foi capaz de identificar 524 amostras de um total de 614 amostras e pode ser uma alternativa de baixo custo (108). Além disso, outros trabalhos mostram a genotipagem do VHC através de sondas FRET e análise de "melting curve" (109). Haverstick (2004)(110)desenhou sondas FRET para identificação do VHC dos tipos 1, 2a/c, 2b, 3a e 3b/4. Entre os 532 pacientes analisados a genotipagem foi determinada em 517 pacientes. Outra pesquisa utilizou a tecnologia "Lightcycler" através de oligonucleotídeos marcados com fluoróforos. Os diferentes genótipos foram identificados através de suas diferentes $T_{m}$ (temperatura de "melting") que eram medidos em dois canais de emissão: F2 LC "Red" 640 para os genótipos 1 e 3 que possuem $T_{m s}$ similares, enquanto que os genótipos 2 e 4 foram identificados pela diferença de suas $T_{m s}$. Para diferenciar os genótipos 1 e 3 realizou-se uma nova leitura no canal F3 LC Red 705 (111). Outro estudo demonstra a genotipagem do VHC através de análise de "melting curve" utilizando o fluoróforo SYBR Green I (112).

e) Outros métodos de genotipagem na região 5'UTR

Piroseqüênciamento é um método não elétroforético de seqüênciamento do DNA que monitora o pirofosfato (PPi) liberado durante a incorporação dos 
nucleotídeos. É um método rápido e acurado de seqüênciamento que elimina a necessidade de nucleotídeos marcados, mas o seu limite é para seqüências de 50 nucleotídeos. Elahi (2003) (113), descreveu um ensaio multiplex com três "primers" de seqüênciamento para obter seqüências de 140 nucleotídeos da região 5 UTR e genotipar o VHC. Embora não seja acurado para a subtipagem por se focado na região 5 UTR.

O teste de genotipagem através da análise da mobilidade do heteroduplex se baseia na formação de "mismatches" quando duas moléculas divergentes de DNA são misturadas, desnaturadas e reaneladas. Este processo resulta na formação de homoduplexes e heteroduplexes e vão migrar em velocidades diferentes quando submetidas a eletroforese em gel de poliacrilamida PAGE). O "mismatch" reduz a mobilidade dos heteroduplexes e a diminuição é proporcional à divergência das duas seqüências (114) (115).

\subsubsection{Métodos comerciais para genotipagem do VHC}

Inúmeros métodos comerciais estão disponíveis para a genotipagem do VHC, destes a maioria são focados na região 5'UTR. Isto se deve, pelo alto grau de conservação entre os isolados dos diferentes genótipos e vários estudos demonstram uma boa correlação quando comparados com a região NS5B (116). Por outro lado, esses métodos possuem uma deficiência em diagnosticar os subtipos ou mesmo genótipos. Por exemplo, o genótipo 6 prevalente no sudeste da Ásia pode ser identificado como genótipo 1, devido ao fato que algumas variantes possuem seqüências "like"- 1 e vice versa possívelmente devido à recombinação genética (117) (43). Os métodos 
comerciais disponíveis no mercado estão descritos abaixo, embora nem todos sejam comercializados no Brasil.

a) Hibridização reversa - Versant ${ }^{\circ}$ HCV genotype Assay (LiPA)

É um dos métodos comerciais mais utilizados em laboratórios clínicos. O método de hibridização reversa utiliza "primers" biotinilados para amplificar a região 5'UTR do VHC, através da RT-PCR. O produto marcado com biotina então é hibridizado numa membrana de nitrocelulose que já está impregnado com sondas específicas para cada genótipo. Adiciona-se à reação estreptavidina marcada com fosfatase alcalina, que converte o substrato NBT/BCIP em um precipitado colorido (Figura 8) (118). A determinação do genótipo se dá através de um perfil específico para cada genótipo Como o método diferencia alguns subtipos pela diferença de um único nucleotídeo a temperatura de hibridização é crucial (The VERSANT HCV Genoype Assay (LiPA). Bayer, 2002. Bula).

Embora diferentes estudos mostrem uma boa correlação quando comparados com seqüênciamento da região NS5B, LiPA não consegue distinguir entre variantes do genótipo 1 e variantes do genótipo 6 presentes no Sudeste da Ásia (52).

Atualmente está em curso uma nova versão do LiPA que utiliza a região do core e 5'UTR o que poderá discriminar melhor tanto os genótipos como os subtipos (119). Uma das vantagens do LiPA é que qualquer produto de RT-PCR que utiliza "primers" biotinilados como vários kits comerciais, para detecção qualitativa ou quantitativa do VHC poderá ser utilizado diretamente pelo LiPA, embora isso acrescente um custo extra ao teste. Um dos 
problemas que o LiPA apresenta é a presença de bandas não específicas o que dificulta a correta interpretação. Além disso, LiPA não identifica bem em pacientes com carga viral abaixo de $10.000 \mathrm{Ul} / \mathrm{ml}$ limitando o seu uso nestes casos (120). O custo por teste é de cerca de $R \$ 300,00$ excluindo os custos da RT-PCR, equipamentos de lavagens e de hibridização, além do tempo requerido para a realização do teste é em torno de 16 horas.

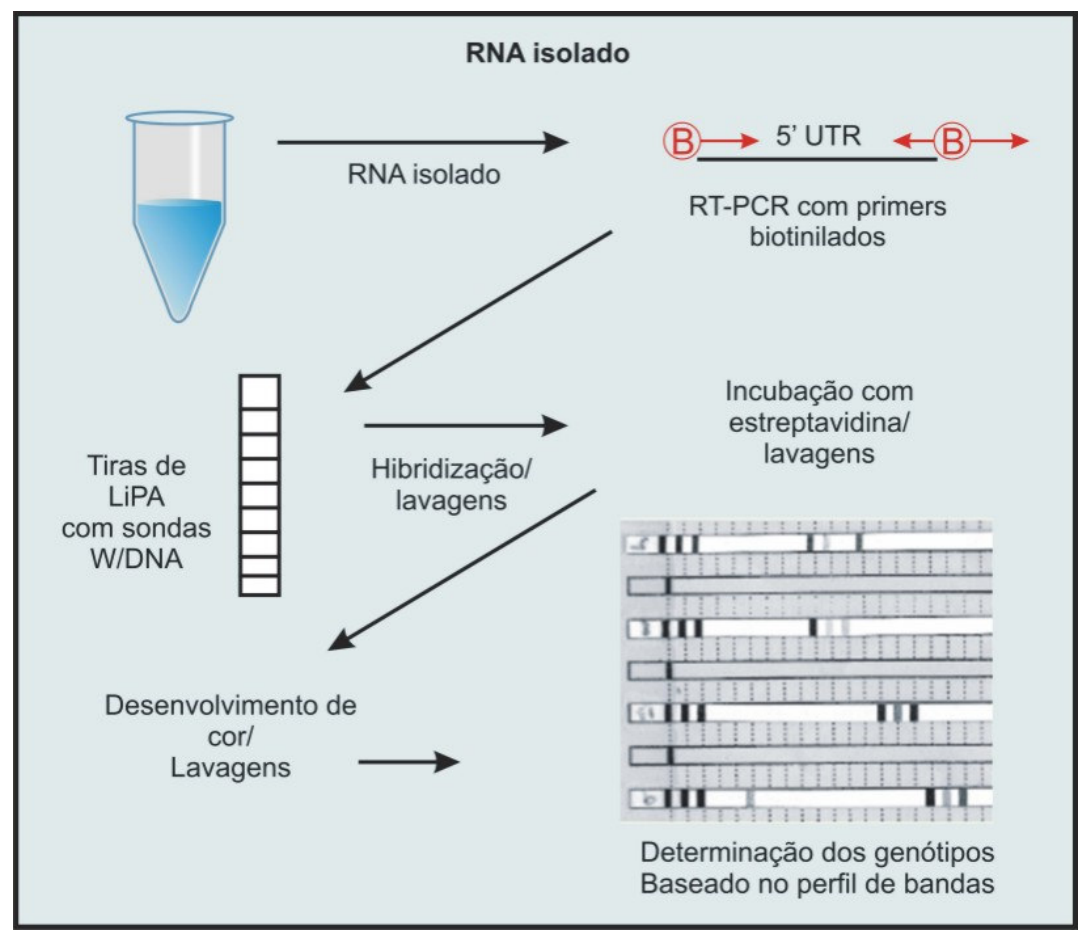

Figura 8 - llustração dos passos necessários para a realização da genotipagem através da técnica de hibridização reversa-LiPA

FONTE: Weck (2005)

b) Seqüênciamento da região 5'UTR - Trugene 5'UTR HCV genotyping

É o seqüênciamento baseado diretamente da região 5'UTR do genoma do VHC. O kit fornece reagentes de seqüênciamento com reações realizadas em um único tubo com fluorescência bidirecional (CLIP seqüenciamento), além do instrumento e softwares para análises (Figura 9). O software analisa os dados 
em tempo real, alinha e compara as seqüências obtidas com seqüências referências da biblioteca do software para tipo, subtipo e isolados próximos. Este método pode ser utilizado através de "amplicons" gerados por kits comerciais após uma purificação por coluna. Há um alto custo na aquisição do equipamento e reagentes. O custo por reação é de aproximadamente U\$100 por teste. Estudos mostram uma boa correlação entre este teste e outros testes focados na região 5'UTR, como o LiPA (119) (121). Isto é esperado pelo fato de que os dois testes focam a região 5'UTR. Desse modo, a habilidade do Trugene 5'UTR em identificar os subtipos é bem menor quando comparado com análises filogenéticas da região NS5B (119) (121). Isto pode gerar interpretações equivocadas porque não foi realizado a partir de uma região filogeneticamente mais informativa, como o NS5B apesar de ser realizado por seqüenciamento.

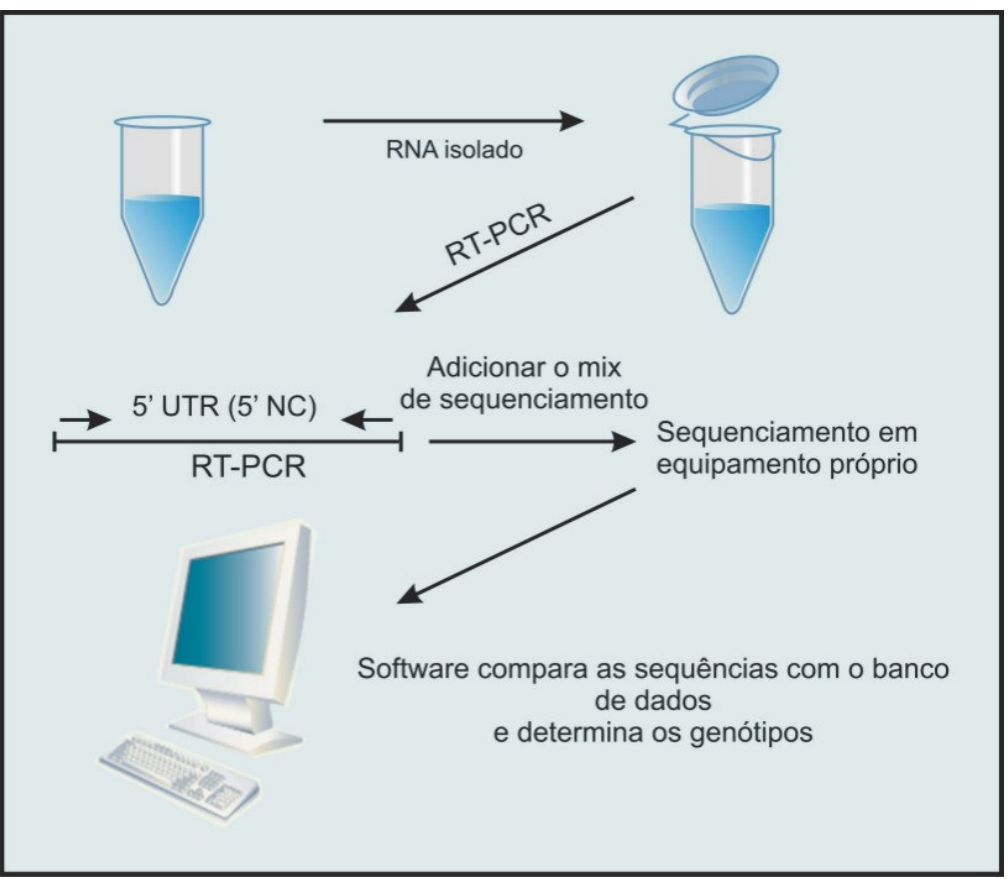

Figura 9 - llustração do esquema de genotipagem pelo método de seqüenciamento TRUGENE 5'UTR

FONTE: Weck (2005) 
c) Invader HCV ASR

Este teste é baseado na utilização de uma enzima que cliva as estruturas secundárias que são formadas quando o DNA é desnaturado e rapidamente renaturado. Este teste é somente um sistema de detecção e a RT-PCR deve ser realizado a priori com primers biotinilados ou não. Como o teste é baseado na região 5UTR pode ser usado em conjunto com produtos amplificados de kits comerciais para detecção qualitativa ou quantitativa. Após a RT-PCR, cada amostra é diluída, desnaturada e distribuída em 8 poços com a enzima cleavase I e sondas Invader que diferenciam os genótipos 1 e 6 . A placa é incubada por 30 minutos a $63^{\circ} \mathrm{C}$ e é realizada leitura numa leitora de placa. O software analisa os dados e determina os genótipos (84). O desenho esquemático do método está apresentado na Figura 10.

Um dos aspectos do kit é que ela só determina o genótipo e não os subtipos. Um estudo comparativo entre três métodos de genotipagem (Trugene, Invader, Real Time da Abbott), os métodos foram capazes de determinar os genótipos em 99,3\%, 88,3\% e 56,2\% respectivamente (122).

Outro dado mostrou uma concordância de $98 \%$ quando realizado com o Trugene HCV 5' NC (121). 


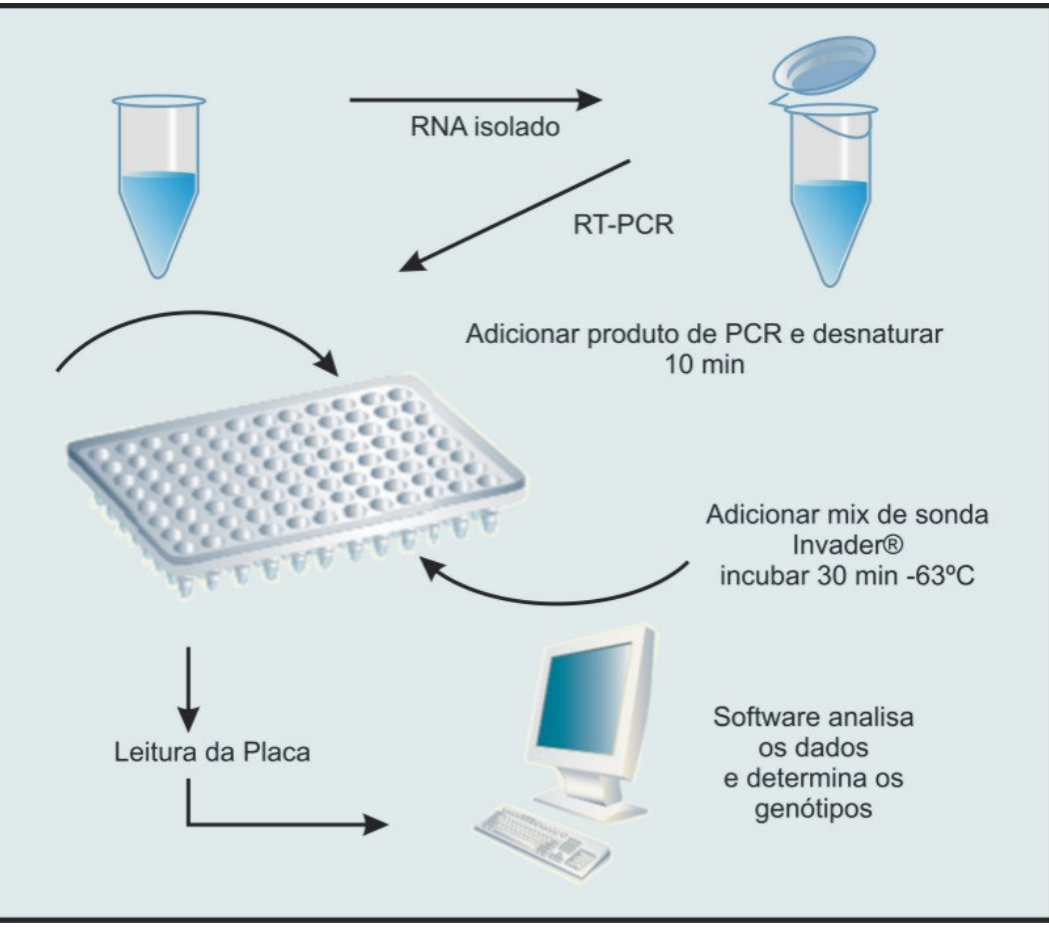

Figura 10 - llustração do método "Invader" para a genotipagem do VHC FONTE: Weck (2005)

\section{d) Abbot HCV ASR}

Abbot ASR é uma reação em "one step" por PCR em tempo real que utiliza sondas específicas para a determinação dos genótipos. Os "primers" e sondas são baseados na região 5'UTR com exceção dos genótipos 1a e 1b que utilizam "primers" e sondas focadas na região NS5B (Figura 11). A diferenciação dos subtipos outros que não 1a e 1b tem um desempenho igual a outras metodologia focadas na região 5'UTR (84).

Estudos prévios mostraram uma boa correlação com o LiPA, mas indicam que a sonda do genótipo 4 não tem a especificidade esperada e pode ocorrer uma falha na identificação desse genótipo (123). Outro estudo mostra que houve uma diferença na eficiência da reação para os diferentes genótipos e para a amplificação do VHC total. Esta variabilidade dificultou a 
utilização dos valores de Ct (cycle treshold) mostrando que há necessidade de sondas com especificidade e eficiência maiores (124).

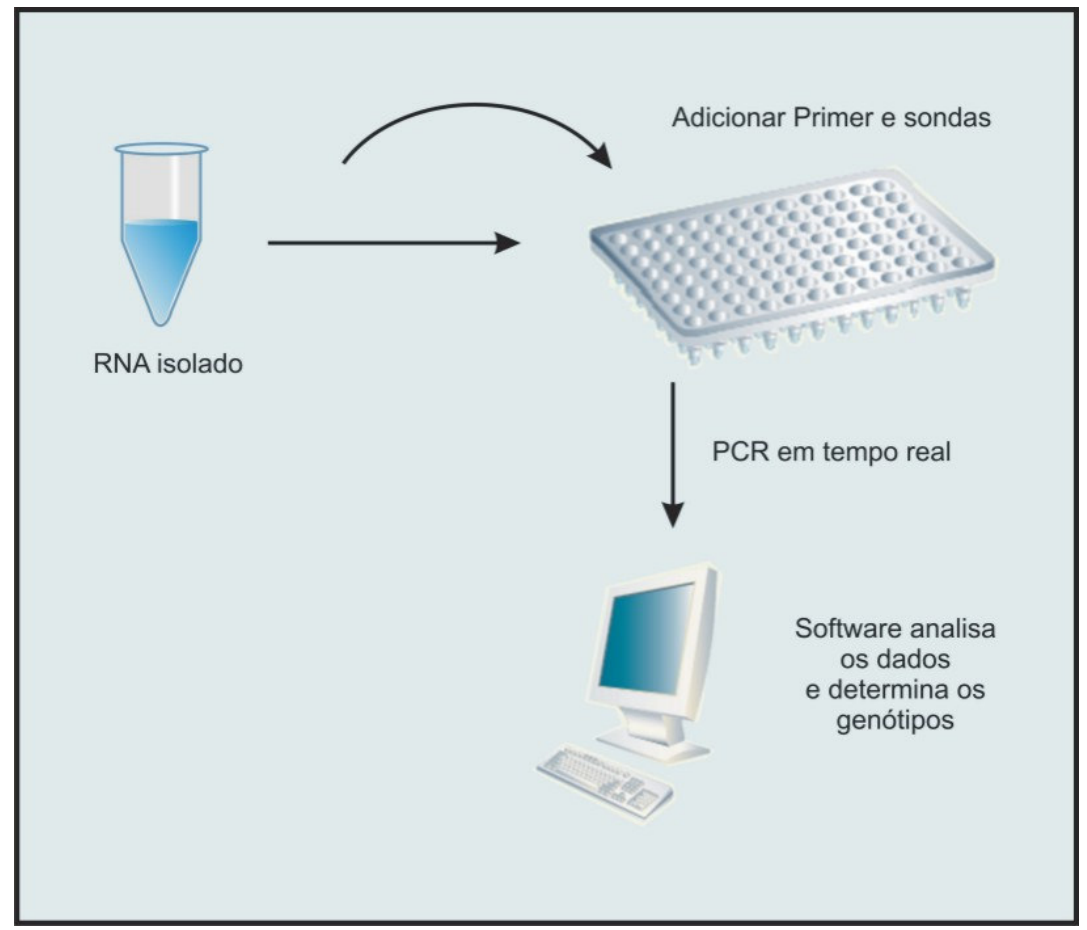

Figura 11 - Ilustração do esquema de genotiapgem do VHC por PCR em tempo real HCV-ASR

FONTE: Weck (2005)

e) TRUGENE NS5B sequencing assay

Este teste está em desenvolvimento pela Visible Genetics/ BayerDiagnostics. O teste incorpora seqüências da região NS5B que são filogeneticamente mais informativas e como padrão ouro podem discriminar também os subtipos de modo preciso. Uma avaliação recente do protótipo mostrou que este é superior ao TRUGENE 5'UTR para a determinação do subtipo, mas falha em aproximadamente $10 \%$ das amostras (125). 
f) DNA enzima imunoensaio

O teste baseado em DNA enzima imunoensaio (DEIA) GEN-ETI-K DNA é disponível através da Sorin Biomédica. Neste ensaio, sondas marcadas genótipo específicas da região do core são ligados em poços de placas em microdiluiçoes. Produtos de RT-PCR são hibridizados e detectados com anticorpos monoclonais específicos contra a fita dupla de DNA. Este ensaio possui boa correlação quando comparado com outros métodos (78) (126) mas não é amplamente utilizado.

\section{g) Ensaios de sorotipagem}

Vários grupos desenvolveram ensaios para detectar anticorpos genótipos específicos que reaja com epítopos imunodominantes na região NS4 ou na região do core. Estes anticorpos podem diferenciar os genótipos, mas não os subtipos de cada genótipo. Estes testes não são amplamente utilizados, pois no geral não possuem a acurácia dos métodos moleculares (127).

Dois ensaios comerciais estão disponíveis no mercado. Serotyping 1-6 assay (Murex Diagnóstica) é um teste competitivo de enzima imunoensaio (EIA) que utiliza peptídeos sintéticos derivados da região NS4 e do core para detectar anticorpos específicos dos genótipos 1 à 6 (128). 0 teste RIBA serotyping SI assay (Chiron) é um imunoblot recombinante com peptídeos sorotipo-específicos da região do NS4 e do core imobilizados numa tira (129). O teste de RIBA detecta somente annticorpos dos genótipos 1 a 3, enquanto que o teste de Murex EIA teóricamente detecta genótipos de 1 à 6 . Em estudo comparando estes testes com LiPA, a concordância encontrada com Murex e Chiron foi de 93 e $88 \%$, respectivamente. A 
sensibilidade foi de 87 e 80 respectivamente (127). Ambos os métodos não possuem uma sensibilidade e especificidade comparáveis aos métodos moleculares de genotipagem e seu uso clínico não é recomendado para acompanhamento de tratamento. Entretanto, ensaios de sorotipagens podem ser úteis para aqueles pacientes que têm a carga viral muito baixo e que não é detectável pelos métodos moleculares.

A tabela 1 detalha as diferenças entre os vários métodos de genotipagem.

Tabela 1 - Comparação dos métodos moleculares comerciais com o seqüenciamento (padrão ouro) para a genotipagem do VHC

\begin{tabular}{|c|c|c|c|c|c|c|}
\hline Método & $\begin{array}{l}\text { Região } \\
\text { do HCV }\end{array}$ & $\begin{array}{c}\text { Custo } \\
\text { US\$ }\end{array}$ & $\begin{array}{c}\text { Tempo } \\
\text { de } \\
\text { execução } \\
\text { horas }\end{array}$ & Genótipos & Subtipos & Problemas \\
\hline $\begin{array}{l}\text { Hibridização } \\
\text { reversa-LiPA }\end{array}$ & 5'UTR & $\sim 72$ & $\begin{array}{c}\text { 4-5h } \\
\text { Pós-PCR }\end{array}$ & $1-6$ & $\begin{array}{c}\text { Identificação } \\
\text { imprecisa } \\
\text { para } \\
\text { genótipos } \\
1,2,4 \text { e } 6\end{array}$ & $\begin{array}{c}\text { Bandas } \\
\text { inespecíficas } \\
\text { Identificação } \\
\text { incorreta do } \\
\text { genótipo } 6\end{array}$ \\
\hline $\begin{array}{c}\text { Seqüencia } \\
\text { mento } \\
\text { Trugene 5' UTR }\end{array}$ & 5'UTR & $\sim 100$ & $\begin{array}{c}4-5 \\
\text { Pós-PCR }\end{array}$ & $1-6$ & $\begin{array}{l}\text { Identificação } \\
\text { imprecisa } \\
\text { para os } \\
\text { subtipos dos } \\
\text { genótipos } \\
1,2,4 \text { e } 6\end{array}$ & $\begin{array}{l}\text { Equipamento de } \\
\text { custo alto } \\
\text { Identificação } \\
\text { incorreta do } \\
\text { genótipo } 6\end{array}$ \\
\hline $\begin{array}{l}\text { Sondas Invader } \\
\text { de hibridização }\end{array}$ & 5'UTR & $\sim 95$ & $\begin{array}{c}2-3 \\
\text { Pós-PCR }\end{array}$ & $1-6$ & Não identifica & - \\
\hline $\begin{array}{c}\text { PCR em tempo } \\
\text { real } \\
\text { Abbottl }\end{array}$ & $\begin{array}{l}\text { 5'UTR } \\
\text { NS5B } \\
\text { (gen 1) }\end{array}$ & $\sim 100$ & $2-3$ & $1-6$ & $\begin{array}{c}\text { Identifica } \\
\text { bem } \\
\text { (genótipos } \\
\text { 1a,1b e 3a) } \\
\text { Impreciso } \\
\text { para os } \\
\text { genótipos } 2 \\
4, \text { e } 6\end{array}$ & $\begin{array}{l}\text { Sondas do gen } \\
4 \text { não possui } \\
\text { especificidade }\end{array}$ \\
\hline $\begin{array}{l}\text { Seqüenciamento } \\
\text { Padrão ouro }\end{array}$ & $\begin{array}{l}\text { NS5B/ } \\
\text { Core/E1 }\end{array}$ & $\sim 55$ & $12-16$ & $1-6$ & $\begin{array}{c}\text { Identifica } \\
\text { corretamente }\end{array}$ & $\begin{array}{c}\text { Laborioso } \\
\text { Falhas no } \\
\text { seqüenciamento }\end{array}$ \\
\hline
\end{tabular}




\section{MÉTODOS}

\section{SEQÜENCIAMENTO DAS AMOSTRAS PARA DESENHO DE SONDAS E "PRIMERS" PARA GENOTIPAGEM DO VHC POR PCR EM TEMPO REAL}

\subsection{Casuística}

As amostras de plasma selecionadas foram provenientes de pacientes com hepatite crônica com critérios para tratamento, conforme a portaria n. ${ }^{\circ} 34$, de 28 de setembro de 2007, ou seja, detecção do RNA do VHC por biologia molecular (qualitativo), atividade necro-inflamatória de moderada a intensa (maior ou igual a A2 pela classificação Metavir ou atividade portal ou peri-portal ou peri-septal grau 2 ou maior pela classificação da Sociedade Brasileira de Patologia e; presença de fibrose de moderada a intensa (maior ou igual a F2 pelas classificaçãoes Metavir ou Sociedade Brasileira de Patologia; ter entre 12 e 70 anos e ter contagem de plaquetas acima de $50.000 / \mathrm{mm}^{3}$ e de neutrófilos acima de $1.500 / \mathrm{mm}^{3}$.

Para a primeira fase deste trabalho, com o intuito de gerar as seqüências para o desenho dos "primers" e sondas foram utilizadas 73 amostras de plasmas de pacientes com infecção crônica pelo VHC de diferentes genótipos, coletados entre novembro de 2005 à agosto de 2006, préviamente caracterizadas pelo LiPA, provenientes do Laboratório Central do Estado LACEN-PR. 
Para a validação do método desenvolvido e comparação com LiPA e seqüenciamento da região NS5B outras duzentos e nove amostras foram provenientes de pacientes triados no Hospital das Clínicas da Universidade de São Paulo (USP). Outras cento e dez amostras foram provenientes do Laboratório Central do Estado do Paraná (LACEN-PR) no período de 2005 a 2008. Nas amostras do LACEN-PR foram realizadas na mesma amostra a genotipagem do VHC pelos dois métodos LiPA e PCR em tempo real enquanto que nas amostras do HC de São Paulo a genotipagem pelo método da PCR em tempo real foi realizada em outra amostra e coletada em tempo diferente que quando caracterizada pelo LiPA.

\subsection{Comitê de Ética}

O projeto foi aprovado pela Comissão de Ética para Análise de Projetos de Pesquisa (CAPPesq) da Diretoria Clínica do Hospital das Clínicas e da Faculdade de Medicina da Universidade de São Paulo, em sessão de 14.09.05 sob o n. ${ }^{\circ} 586 / 05$.

\subsection{Amostras de plasma}

O sangue total foi coletado em tubos Vacutainer ${ }^{R}$ (Becton-Dickinson, Plymouth, United Kingdom), contendo anticoagulante EDTA (ácido etileno diamino tetracético) para a extração do RNA do VHC. Foi, então, centrifugado 
dentro de no máximo 2 horas e o plasma separado em frasco livre de Rnase e Dnase e acondicionado $\mathrm{a}-20^{\circ} \mathrm{C}$ até o momento da extração do RNA.

\subsection{Extração do RNA}

O RNA do VHC foi extraído de acordo com o método de Boom (130) utilizando partículas de sílica magnetizadas de acordo com as instruções do fabricante, Nuclisens ® Magnetic Extration Reagents (bioMérieux, Boxtel, The Netherlands) como se segue: o tampão de lise foi previamente colocado em $\mathrm{BM}$ a $37^{\circ} \mathrm{C}$ por 30 minutos para a dissolução dos cristais presentes. O RNA foi extraído a partir de $200 \mu$ do plasma e adicionado a $2000 \mu \mathrm{l}$ do tampão de lise (tiocianato de guanidina $5 \mathrm{~mol} / \mathrm{L}$, triton $\mathrm{X}-100$, Tris $\mathrm{HCl}, \mathrm{pH}: 7,4$ ). Os tampões de lise com as amostras foram mantidos a temperatura ambiente por 10 minutos. Adicionaram-se $50 \mu \mathrm{l}$ de sílica magnetizada (que serve como fase sólida e tem como característica elevada concentração de sal, o que permite que os ácidos nucléicos se liguem às partículas de sílica magnetizadas), sendo estas amostras mantidas à temperatura ambiente por 10 minutos. Os tubos foram centrifugados por 2 min a $1500 \mathrm{Xg}$. Realizaram-se os procedimentos de purificação em uma estante com placa magnetizada com $400 \mu$ lampão de lavagem 1 (tiocianato de guanidina) e com $500 \mu$ le tampão de lavagem 2 (tampão orgânico, solução biocida) por 2 vezes cada. Em seguida, foram lavadas com tampão de lavagem 3 (tampão inorgânico) e eluídos com $50 \mu$ l de tampão de eluição (tampão inorgânico) a $60^{\circ} \mathrm{C}$ por 5 min com agitação de 
1400 rpm. Por fim, o eluído foi separado da sílica, acondicionado em tubos de rosca e colocado para a reação de transcriptase reversa.

\subsection{Procedimentos para a realização da PCR}

Todos os procedimentos da PCR foram realizados na Seção de Biologia Molecular do Laboratório Central do Estado (LACEN-PR). Para evitar contaminação, todos os procedimentos (preparação do "master mix", extração do RNA, amplificação e detecção) foram realizados em salas separadas. Os procedimentos referentes ao preparo do "master mix" e extração do DNA foram realizados em Cabines de Segurança tipo II, em suas respectivas salas. Para validar os resultados da PCR, todas as análises foram realizadas com controles negativos e positivos.

\subsubsection{Desenho dos "primers"}

Foi necessário realizar o desenho dos "primers" de uma região conservada do NS5B. Para isto, foram alinhadas seqüências consensos de diferentes genótipos do VHC 1a, 1b, 2a, 2b, 3a, disponíveis: http://hcv.lanl.gov/ content/sequence/NEWALIGN/align.html, Los Alamos National Laboratory. A partir destes "primers" NS5B-2F e NS5B-2R foram realizados os procedimentos de PCR, seqüenciamento e alinhamento das seqüências das amostras do VHC que tiveram como objetivo o desenho dos "primers" e sondas específicas para cada genótipo e o desenvolvimento e padronização da técnica de 
genotipagem por PCR em tempo real. A Tabela 1 mostra as seqüências dos "primers" da região NS5B.

Tabela 2 - "Primers"'"utilizado para a amplificação da região NS5B do VHC

\begin{tabular}{|c|c|c|c|c|}
\hline $\begin{array}{l}\text { NOME DO } \\
\text { "PRIMER" }\end{array}$ & GENÓTIPO & SEQÜÊNCIAS & $\begin{array}{c}\text { PRODUTO } \\
\mathrm{pb}\end{array}$ & $\begin{array}{c}\text { POSIÇÃO } \\
\text { NA } \\
\text { REGIÃO } \\
\text { NS5B }\end{array}$ \\
\hline $\begin{array}{l}\text { NS5B2F } \\
\text { NS5B2R }\end{array}$ & $\begin{array}{l}\text { Genótipos } \\
1 \text { a } 5\end{array}$ & $\begin{array}{l}\text { 5'-TTCACGGAGGCTATGACYAGG-3' } \\
\text { 5'-CGGGCATGMGACASGCTGTGA-3' }\end{array}$ & $688 \mathrm{pb}$ & \begin{tabular}{|l|}
$1017-1038$ \\
$1704-1683$ \\
\end{tabular} \\
\hline
\end{tabular}

\subsubsection{RT-PCR}

A síntese do cDNA foi realizada a partir de preparo do "random mix" 36,3 $\mu \mathrm{l} \mathrm{H}_{2} \mathrm{O}$ DEPC q.s.p $36 \mu \mathrm{l}$ e $3,3 \mu \mathrm{l}$ de "random primer" $150 \mathrm{ng} / \mu \mathrm{l}$ e adicionadas $50 \mu \mathrm{l}$ do RNA eluído, incubados por 10 min a $70^{\circ} \mathrm{C}$ no termociclador GeneAMP PCR Systems 9700 (Applied Biosystems, Foster, CA, USA). Os tubos foram transferidos para o gelo e adicionados $24 \mu$ do RT mix $(13,2 \mu \mathrm{l}$ de tampão $5 X(250 \mathrm{mM}$ Tris- $\mathrm{HCl}$ ph 8.3, $375 \mathrm{mM} \mathrm{KCl}, 15 \mathrm{mM} \mathrm{MgCl}$ ), $6,6 \mu \mathrm{l}$ DTT $0,1 \mathrm{M}, 3,3 \mu \mathrm{l}$ de dNTPs $(10 \mathrm{mM}), 1,1 \mu \mathrm{l}$ de Rnase out (30 un/ $\mu \mathrm{l})$, $0,55 \mu \mathrm{l}$ de $\mathrm{H}_{2} 0$ DEPC q.s.p para $24 \mu \mathrm{l}$ e 1,65 $\mu \mathrm{l}$ de RT MMLV (200 U/ $\left.\mu \mathrm{l}\right)$. Todos os reativos utilizados foram da (Invitrogen, Carlsbad, CA, USA). As condições de ciclagem foram as seguintes: $25^{\circ} \mathrm{C}$ por $15 \mathrm{~min}, 37^{\circ} \mathrm{C}$ por 62 $\min , 95^{\circ} \mathrm{C}$ por $15 \min$ e $10^{\circ} \mathrm{C}$ indefinidamente. 


\subsubsection{Padronização da reação de PCR}

A reação de PCR com os "primers" desenhados NS5B-2F e NS5B-2R foi otimizada com a realização de gradiente de temperatura que variou de $45^{\circ} \mathrm{C}$ a $65.6^{\circ} \mathrm{C}$ no termociclador Mastercycler Gradient (Eppendorf, Hamburg, Ge).

\subsubsection{PCR da região NS5B do VHC}

A reação foi realizada em um volume total de $50 \mu \mathrm{l}$, sendo $5 \mu \mathrm{l}$ do tampão PCR concentrado 10X (600 mM Tris-SO $\left.{ }_{4} \mathrm{pH} 8.9,180 \mathrm{mM}\left(\mathrm{NH}_{4}\right) \mathrm{SO}_{4}\right)$, $3 \mu \mathrm{l}$ de $\mathrm{MgSO}_{4} 50 \mathrm{mM}, 8 \mu \mathrm{l}$ de dNTPs $(200 \mathrm{mM}), 0,35 \mu \mathrm{l}$ de cada "primer" (50 pmol/ $\mu \mathrm{l}$ ), $0,5 \mu \mathrm{l}$ de Taq DNA polimerase "high fidelity" $5 \mathrm{U} / \mu \mathrm{l}$ e $5 \mu \mathrm{l}$ do CDNA. As amplificações foram realizadas no termociclador GeneAMP PCR Systems 9700 (Applied Biosystems, Foster, Ca, USA) com 35 ciclos de $95^{\circ} \mathrm{C}$ por $30 \mathrm{~s}, 60,5^{\circ} \mathrm{C}$ por $1 \mathrm{~min}, 72^{\circ} \mathrm{C}$ por $1 \mathrm{~min}, 1$ ciclo de $72^{\circ} \mathrm{C}$ por $10 \mathrm{~min} \mathrm{e}$ $10^{\circ} \mathrm{C}$ indefinidamente.

\subsubsection{Detecção e análise do produto da PCR}

A detecção dos produtos de PCR foi feita através de eletroforese em gel de agarose tipo II eletroendosmose $0.09-0.13 \mathrm{mr} 1,5 \%$ (Invitrogen), sendo corado com Syber Safe ${ }^{\circledR}$ (Invitrogen, Carlsbad, Ca, USA) numa concentração final de $0,5 \mu \mathrm{g} / \mathrm{ml}$ em tampão TBE $1 \mathrm{X}$ (tris-borato EDTA). Em cada poço do gel de agarose foram pipetadas $4 \mu \mathrm{l}$ do DNA amplificado de cada amostra, 
$1 \mu \mathrm{l}$ de corante azul de bromofenol $0,2 \%$ e o marcador de peso molecular. A eletroforese foi realizada a 150 volts, por 45 minutos.

A visualização das bandas foi realizada em um transiluminador ultravioleta (Uniscience, Brasil). Comparando-se o DNA ladder 100pb (Invitrogen) com os fragmentos amplificados com as bandas que possuíam o tamanho esperado e igual ao controle positivo, sendo que este foi critério para diagnosticar os resultados da PCR destas amostras. A fotodocumentação foi realizada através de câmara digital (Kodak Digital Science - Eletrophoresis Documentation and Analysis System 120 Rochester, NY USA).

\subsection{Seqüenciamento da Região NS5B do VHC}

\subsubsection{Purificação dos produtos da PCR}

Os produtos de PCR foram purificados conforme instruções do fabricante do kit PureLink ${ }^{\mathrm{TM}}$ PCR Purification (Invitrogen, Carlsbad, CA, USA). Foi adicionado 4 vezes o volume do produto de PCR em tampão de ligação com isopropanol. A mistura foi colocada na coluna e centrifugada por $1 \mathrm{~min}$ a $10.000 \mathrm{Xg}$. O filtrado foi descartado e a coluna colocada novamente no tubo coletor e realizados os procedimentos de purificação com $650 \mu \mathrm{l}$ de tampão de lavagem com etanol, centrifugado a temperatura ambiente por 1 min a $10.000 \mathrm{Xg}$. O novo filtrado foi novamente descartado e a coluna recolocada em tubo coletor. Novamente centrifugado na velocidade máxima por 2-3 minutos para remover resíduos do tampão de lavagem. O DNA foi 
eluído com $50 \mu \mathrm{l}$ de tampão de eluição $(10 \mathrm{mM}$ Tris-HCl, $\mathrm{pH}$ 8,5), incubado à temperatura ambiente por 1 min e centrifugado à velocidade máxima por 2 min. As amostras foram estocadas à $-20^{\circ} \mathrm{C}$.

\subsubsection{Quantificação do produto purificado}

Os produtos de purificação foram quantificados através de um padrão de quantificação (Low Dna Mass Ladder 470 ng Invitrogen, Carlsbad, CA, USA) em gel de agarose 1,5\% com o corante syber safe® (Invitrogen). Após captura e digitalização da imagem, os produtos foram quantificados utilizando o programa de análise KODAK DC120 (Kodak Digital Science - Eletrophoresis Documentation and Analysis System 120 Rochester, NY USA), conforme descrito no manual de instruções do programa. Em seguida as amostras foram diluídas com água ultra pura para $20 \mathrm{ng}(5 \mu \mathrm{l}$ a $4 \mathrm{ng} / \mu \mathrm{l})$

\subsubsection{Reação de seqüenciamento}

A reação de seqüenciamento foi realizada em um volume total de $10 \mu \mathrm{l} \mathrm{com} \mathrm{o} \mathrm{Big} \mathrm{Dye} \mathrm{terminator} \mathrm{v.3.1} \mathrm{(Applied} \mathrm{Biosystems,} \mathrm{Foster,} \mathrm{CA,} \mathrm{USA),}$ sendo $2 \mu \mathrm{l}$ de big dye, $2 \mu \mathrm{l}$ de tampão de seqüenciamento $5 \mathrm{X}, 0,2 \mu \mathrm{l}$ de "primer" F e R (3,2 pmol) e $0.8 \mu \mathrm{l}$ de água ultra pura e $5 \mu \mathrm{l}(20 \mathrm{ng})$ do produto de PCR purificado. As reações foram realizadas no termociclador GeneAMP 
PCR Systems 9700 (Applied Biosystems, Foster, CA, USA) com 1 ciclo de $96^{\circ} \mathrm{C}$ por $1 \mathrm{~min}, 35$ ciclos de $96^{\circ} \mathrm{C}$ por $10 \mathrm{~s}, 50^{\circ} \mathrm{C}$ por $5 \mathrm{~s}$ e $60^{\circ} \mathrm{C}$ por $4 \mathrm{~min}$. Após o término da ciclagem, os produtos foram imediatamente purificados.

\subsubsection{Purificação dos produtos seqüenciados}

Os produtos da reação de seqüenciamento foram purificados utilizando método "in house" de precipitação com isopropanol. Foram adicionados a cada amostra $40 \mu \mathrm{l}$ de isopropanol (Merck, PA) diluído a 75\%, homogeneizados com o pipetador. As amostras foram incubadas por 20 minutos à temperatura ambiente. Em seguida, centrifugadas a 2.500 rpm, por 60 minutos a temperatura ambiente. O sobrenadante foi descartado e foram adicionados às amostras $200 \mu \mathrm{l}$ de etanol (Merck, PA) diluído a 70\%, sendo novamente centrifugadas a 2.500 rpm por 15 minutos à temperatura ambiente. O sobrenadante foi novamente descartado e as amostras foram submetidas à centrifugação invertida a 800 rpm por 5 segundos (spin), para remover o etanol residual. As amostras foram secadas a temperatura ambiente por 20 minutos e imediatamente ressuspendidas em $10 \mu \mathrm{l}$ de Formamida Hi-Di (Appllied Biosystems, Foster, CA, USA). As amostras foram desnaturadas no termociclador AB 9700 a $96^{\circ} \mathrm{C}$ por 3 minutos. 


\subsubsection{Seqüenciamento dos produtos}

As amostras foram submetidas à detecção no seqüenciador automático AB 3130 (Applied Biosystems, Foster, CA, USA), utilizando capilar de $50 \mathrm{~cm}$, polímero de acrilamida POP7 (Applied Biosystems, Foster, CA, USA) e programação padrão de corrida para esses parâmetros.

\subsubsection{Análises das seqüências}

As seqüências geradas foram analisadas pelo programa Seqscape (Applied Biosystems, Foster, CA, USA) e reanalizadas através do programa Codon Code (Codon Code corporation, Dedham, MA, USA) e alinhadas pelo Biedit (Hall, 1999), com a utilização de um painel de referência disponível em: http://hcv.lanl.gov/content/hcv-db/HTML/ToolsOutline.html, Los Alamos National Laboratory.

\subsubsection{Número de acesso no GenBank}

Vinte e três amostras de diferentes genótipos, seqüenciadas neste estudo, com seqüências parciais da região NS5B do VHC, foram submetidas ao GenBank e podem ser acessadas como se segue: 1a (EF136876 to EF136882); 1b (EF136870, EF136872, EF136873, EF1368874, EF136875, 
EF136883), 2b (EF136869); 2c (EF136868); 3a (EF136860 to EF136865); 4a (EF136867); 5a (EF136859).

\subsection{Genotipagem do VHC pelo método LiPA}

O RNA viral foi extraído, amplificado e detectado a partir de $200 \mu \mathrm{l}$ de plasma de acordo com as instruções do fabricante- Amplicor® Hepatitis C Vírus - HVC - Test, version 2.0 (Roche, Branchburg, NJ, USA), através da lise das partículas virais com tiocianato de guanidina, seguida de precipitação do RNA com álcool. Um fragmento curto de RNA introduzido junto com o tampão de lise funciona como controle de extração e amplificação de cada amostra. O RNA do VHC foi retrotranscrito para CDNA e amplificado através de RT-PCR. O teste utiliza os iniciadores KY78 e KY80 para definir uma sequência de 244 nucleotídeos dentro da região conservada 5' NC do genoma. A detecção do DNA amplificado foi executada usando sondas oligonucleotídicas específicas para o alvo o que permite a identificação dos amplicons do VHC e do controle interno. O amplicon biotinilado deste teste foi utilizado nos métodos de genotipagem por LiPA. Este foi executado de acordo com as instruções do fabricante do kit VERSANTTMHCV Genotype Assay-LiPA (Bayer, Tarrytown, NY, USA) que é baseado na hibridização reversa e utiliza sondas oligonucleotídicas específicas imobilizadas em uma tira de nitrocelulose. Cada tira contém uma linha de controle do teste e 20 linhas de sondas de DNA paralelas que hibridizam com a região 5'UTR do genoma do VHC. O produto amplificado marcado com biotina foi hibridizado com as sondas da tira em condições de alta estringência. 
Após a hibridização, foi adicionada estreptoavidina marcada com fosfatase alcalina, seguida de uma incubação com o cromógeno BCIP/NBT, que resulta num precipitado púrpuro-marrom. A hibridização dos fragmentos de cDNA amplificados com uma ou mais linhas da tira permite a classificação dos 6 principais genótipos e os seus subtipos mais comuns (1a, $1 b, 2 a / c, 2 b, 3$, 4, 5a e 6a). 


\section{DESENVOLVIMENTO E PADRONIZAÇÃO DA TÉCNICA DE PCR EM TEMPO REAL PARA A GENOTIPAGEM DO VHC}

\subsection{Desenhos de "primers" e sondas}

Os desenhos das sondas e dos "primers" foram realizados a partir das seqüências geradas pelos procedimentos descritos no item 3.6 (seqüenciamento da região NS5B do VHC) e conforme regras preestabelecidas (131), mas sem a utilização de "softwares" para detectar os diferentes geótipos do VHC em uma região conservada do NS5B. As temperaturas dos "primers" e sondas foram calculadas com base no programa Primer Express (Applied Biosystems, Foster, CA, USA). A Tabela 3 mostra os diferentes "primers" e a Tabela 4 as especificações de cada sonda utilizadas nas reações de genotipagem do VHC por tempo real. As Figuras 12 e 13 mostram os desenhos das sondas utilizadas para a reação de genotipagem do VHC por tempo real.

Tabela 3 - Relação dos "primers"utilizados para a amplificação da região NS5B do VHC

\begin{tabular}{|c|c|c|c|c|}
\hline $\begin{array}{l}\text { NOME DO } \\
\text { "PRIMER" }\end{array}$ & GENÓTIPO & SEQÜÊNCIAS & $\begin{array}{c}\text { PRODUTO } \\
\mathrm{pb}\end{array}$ & $\begin{array}{l}\text { POSIÇÃO } \\
\text { NA } \\
\text { REGIÃO } \\
\text { NS5B }\end{array}$ \\
\hline $\begin{array}{l}\text { F56_1-3 } \\
\text { R56_1-3 }\end{array}$ & $\begin{array}{c}\text { Genótipos } \\
1 \text { e } 3\end{array}$ & \multirow{3}{*}{$\begin{array}{c}\text { 5'CACACTCCAGTYAAYTCCTGG-3' } \\
\text { 5'-CWMCTGGAGAGTAACTGTGGAG-3' } \\
\text { 5'-GACACTCCCCTGTCAATTCWTGG- } \\
\text { 3' } \\
\text { 5'-TGGTYCAGAGTGTCYTGGGC-3' }\end{array}$} & $241 \mathrm{pb}$ & $\begin{array}{c}1204-1224 \\
1444-1423\end{array}$ \\
\hline GEN2F & \multirow{2}{*}{$\begin{array}{c}\text { Genótipos } \\
2\end{array}$} & & \multirow{2}{*}{$120 \mathrm{pb}$} & $1202-1224$ \\
\hline GEN2RSN & & & & $1321-1313$ \\
\hline
\end{tabular}

1a_H77.NC_004102 - seqüência referência utilizada para cálculo da posição na região NS5B 


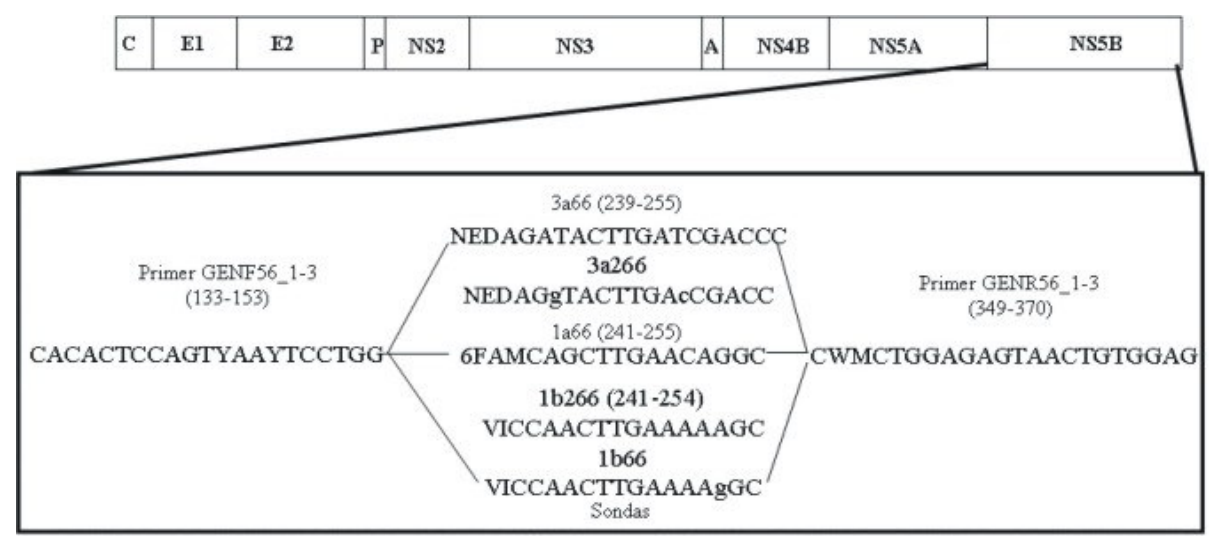

Figura 12 - Representação esquemática do desenho dos "primers" e sondas dos genótipos 1 e 3 marcadas com os respectivos fluoróforos da região NS5B do VHC

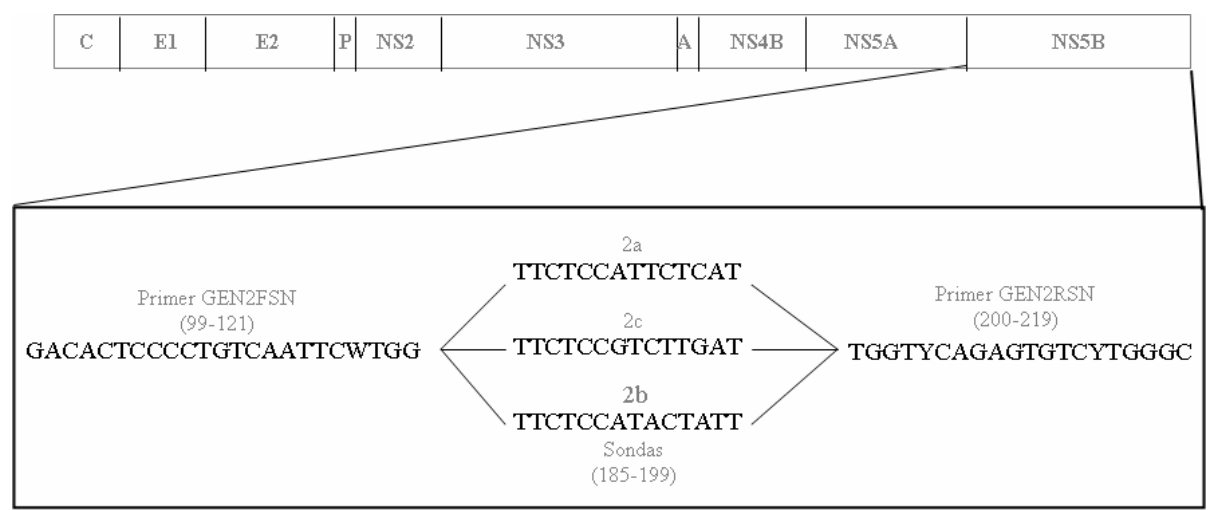

Figura 13 - Representação esquemática dos desenhos dos "primers" e sondas do genótipo 2 marcadas com os respectivos fluoróforos da região NS5B do VHC 
Tabela 4 - Relação das sondas utilizadas no método de genotipagem do VHC por PCR em tempo real

\begin{tabular}{|c|c|c|c|c|c|}
\hline $\begin{array}{l}\text { Nome } \\
\text { da } \\
\text { sonda }\end{array}$ & Genótipo & Fluoróforo & $\begin{array}{l}\text { Seqüências } \\
\left(5^{\prime}-3^{\prime}\right)\end{array}$ & Quencher & $\begin{array}{l}\text { Posição na } \\
\text { região } \\
\text { NS5B }\end{array}$ \\
\hline $1 a 66$ & $1 a$ & 6Fam & CAGCTTGAACAGGC & MGB & $1312-1315$ \\
\hline 1b266 & $1 \mathrm{~b}$ & Vic & CAACTTGAAAAAGC & MGB & $1312-1315$ \\
\hline $1 \mathrm{~b} 66$ & $1 b$ & Vic & CAACTTGAAAAgGC & MGB & $1312-1315$ \\
\hline $3 a 66$ & $3 a$ & Ned & AGATACTTGATCGACCC & MGB & $1310-1316$ \\
\hline $3 a 266$ & $3 a$ & Ned & AGgTACTTGAcCGACCC & MGB & $1310-1316$ \\
\hline $2 a$ & $2 a$ & Ned & ТTСТССАТТСТСАТ & MGB & $1287-1301$ \\
\hline $2 b$ & $2 b$ & 6FAM & ТTСТССАТАСТАТТ & MGB & $1287-1301$ \\
\hline $2 c$ & $2 c$ & Vic & TTCTCCGTCTTGAT & MGB & $1287-1301$ \\
\hline
\end{tabular}

\subsection{Extração do RNA}

Foram utilizadas amostras de plasma de pacientes com genotipagem previamente realizada pelo método LiPA conforme descrita no item 3.7. Para a extração do RNA utilizou-se a plataforma automatizada Nuclisens easyMAG (bioMérieux, Boxtel, Netherlands), baseado no método de sílica magnetizada. O RNA foi extraído a partir de $200 \mu \mathrm{l}$ de plasma e eluído em $60 \mu \mathrm{l}$ de tampão de eluição. A amostra de RNA extraída foi armazenada em freezer $-70^{\circ} \mathrm{C}$ nos casos em que não pôde ser processada imediatamente após a extração do RNA. 


\subsection{Gradiente de temperatura dos "primers"}

Os "primers", antes de serem testados na plataforma de PCR em tempo real, foram otimizados com a realização de gradiente de temperatura que variou de $45^{\circ} \mathrm{C}$ a $65.6^{\circ} \mathrm{C}$ no termociclador Mastercycler Gradient (Eppendorf, Hamburg, Ge), conforme se segue: a reação foi realizada em um volume total de $50 \mu \mathrm{l}$, sendo $5 \mu \mathrm{l}$ do tampão PCR concentrado 10X (600 mM Tris-SO 4 $\mathrm{pH}$ 8.9, $180 \mathrm{mM}(\mathrm{NH} 4) \mathrm{SO} 4), 3 \mu \mathrm{l}$ de sulfato de Magnésio $\left(\mathrm{MgSO}_{4}\right) 50 \mathrm{mM}$, $8 \mu \mathrm{l}$ de dNTPs (200 mM), 0,35 $\mu$ l de cada "primer" (50 pmol/ $\mu \mathrm{l}), 0,5 \mu \mathrm{l}$ de Taq DNA polimerase high fidelity $5 \mathrm{U} / \mu \mathrm{l}$ e $5 \mu \mathrm{l}$ do cDNA. As amplificações foram realizadas no termociclador GeneAMP PCR Systems 9700 (Applied Biosystems, Foster, Ca, USA) com 35 ciclos de $95^{\circ} \mathrm{C}$ por $30 \mathrm{~s}, \Delta 45^{\circ} \mathrm{C}$ a $\pm 5^{\circ} \mathrm{C} 45 \mathrm{~s}, 72^{\circ} \mathrm{C}$ por $1 \mathrm{~min}, 1$ ciclo de $72^{\circ} \mathrm{C}$ por $10 \mathrm{~min}$ e $10^{\circ} \mathrm{C}$ indefinidamente.

\subsection{Padronização da PCR em tempo real "two step"}

\subsubsection{RT-PCR}

A transcrição reversa para a síntese do cDNA foi realizada conforme já descrito no item 3.5.2. 
3.11.2 Realização de matrizes com diferentes concentrações de "primers" e sondas

Amostras de plasmas previamente genotipadas pelo método LiPA foram utilizadas para a realização de matrizes com diferentes concentrações de "primers" e sondas.

A reação foi realizada em um volume total de $25 \mu$, sendo $12,5 \mu$ do tampão TaqMan® Universal Master Mix (Applied Biosystems, Foster Ca, USA) cada "primer sense" e "anti-sense" em diferentes concentrações de $(300,600,900 \mathrm{M})$ e concentrações de 200 e $300 \mathrm{nM}$ para as diferentes sondas para cada genótipo (1a, 1b e 3a), $5 \mu$ l de cDNA e diferentes volume de água ultra pura com quantidade suficiente para $25 \mu$ l. A reação foi processada no equipamento 7500 Real time PCR Systems (Applied Biosystems, Foster CA, USA) com ciclagens de $50^{\circ} \mathrm{C}$ por $2 \mathrm{~min}, 95^{\circ} \mathrm{C}$ por $10 \mathrm{~min}, 45$ ciclos de $95^{\circ} \mathrm{C}$ $15 \mathrm{~s}, 60^{\circ} \mathrm{C}$ por $1 \mathrm{~min}$. A velocidade de incremento da rampa de temperatura foi ajustada para simular ao termociclador 9600 a um volume final de $25 \mu$.

\subsection{Padronização da PCR em tempo real "one step"}

\subsubsection{Reação de PCR em tempo real "one step"}

Nesse procedimento foram testados diversos protocolos quanto ao modo de incubação e quanto ao número de sondas. Uma sonda por reação ficou determinado como "monoplex" e três sondas como "triplex" 
a) Reação "one step": A reação foi realizada com sondas "triplex" com Superscript ${ }^{\mathrm{TM}}$ III Platinum ${ }^{\circledR}$ one-step quantitative RT-PCR system (Invitrogen, Carlsbad, CA, USA), em um volume total de $50 \mu \mathrm{l}$, sendo $25,0 \mu \mathrm{l}$ do tampão PCR $2 X$ (6 mM de sulfato de Magnésio $\left(\mathrm{MgSO}_{4}\right), \quad 0,4 \mathrm{mM}$ de dNTPs), 1,0 $\mu \mathrm{l}$ taq mix (Superscript $^{\mathrm{TM} I I I} \mathrm{RT}$, Platinum Taq Mix), 1,0 $\mu$ de cada "primer sense" F56 1-3 ou gen2FSN (10 $\mu \mathrm{M}), 1,0 \mu \mathrm{l}$ de cada "primer antisense" R56 1-3 ou gen2RSN (10 $\mu \mathrm{M}), 1,5 \mu \mathrm{l}$ de $\mathrm{MgSO}_{4}(50 \mathrm{mM})$, $1,0 \mu \mathrm{l}$ de cada sonda $1 \mathrm{a}, 1 \mathrm{~b} 3 \mathrm{a}$, ou $2 \mathrm{a}, 2 \mathrm{~b}, 2 \mathrm{c}$ perfazendo um volume total de $31 \mu \mathrm{l}$ e adicionados $19 \mu \mathrm{l}$ de RNA no tubo ótico (Applied Biosystems, Foster CA, USA) específico para a reação de tempo real. A reação foi processada no equipamento $\mathbf{7 5 0 0}$ Real time PCR Systems (Applied Biosystems, Foster CA, USA) com $50^{\circ} \mathrm{C}$ por $30 \mathrm{~min}, 95^{\circ} \mathrm{C}$ por $10 \mathrm{~min}, 45$ ciclos de $95^{\circ} \mathrm{C} 15 \mathrm{~s}$, $50^{\circ} \mathrm{C}$ por $30 \mathrm{~s}, 60^{\circ} \mathrm{C}$ por $1 \mathrm{~min}$. A velocidade de incremento da rampa de temperatura foi ajustada para similar ao termociclador 9600 a um volume final de $50 \mu \mathrm{l}$.

b) Reação "one step" com modificação na incubação: Esta mesma reação foi testada com sondas "triplex" com uma incubação de $50^{\circ} \mathrm{C}$ por 35 min no termociclador 9700 com a tampa do equipamento aberta e em seguida no equipamento 7500 Real time PCR Systems (Applied Biosystems, Foster CA, USA) com $50^{\circ} \mathrm{C}$ por $2 \mathrm{~min}, 95^{\circ} \mathrm{C}$ por $10 \mathrm{~min}, 45$ ciclos de $95^{\circ} \mathrm{C} 15 \mathrm{~s}, 50^{\circ} \mathrm{C}$ por $30 \mathrm{~s}, 60^{\circ} \mathrm{C}$ por $1 \mathrm{~min}$. A velocidade de incremento da rampa 
de temperatura foi ajustada para similar ao termociclador 9600 a um volume final de $50 \mu \mathrm{l}$.

c) Reação "one-step" modificado: A reação foi realizada com

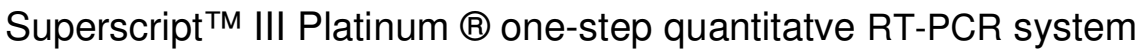
(Invitrogen, Carlsbad, CA, USA), em um volume total de $50 \mu \mathrm{l}$, sendo $18,5 \mu \mathrm{l}$ do tampão PCR 2X (6 mM de sulfato de Magnésio ( $\mathrm{MgSO}_{4}$ ), 0,4 mM de dNTPs), 1,0 $\mu$ l Taq mix (Superscript ${ }^{\mathrm{TM}}$ III RT, Platinum Taq Mix), 1,0 $\mu$ de "primer" R56 1-3 ou gen2RSN (10 $\mu \mathrm{M})$, 0,5 $\mu$ l de Rnase out (Invitrogen, Carlsbad, Ca, USA), perfazendo um volume total de $21 \mu \mathrm{l}$ e adicionados $19 \mu \mathrm{l}$ de RNA em cada tubo ótico (Applied Biosystems, Foster CA, USA) específico para a reação de $\mathrm{PCR}$ em tempo real. Em seguida foram realizados diferentes protocolos para reações "monoplex" e "triplex" como se segue: para a reação "monoplex" foram adicionados $6,4 \mu \mathrm{l}$ do tampão PCR 2X, 1,0 $\mu$ l, "primer" F56 1-3 ou gen2FSN, 1,0 $\mu$ le ROX, $1,5 \mu \mathrm{l}$ de $\mathrm{MgSO}_{4}(50 \mathrm{mM}), 1,0 \mu \mathrm{l}$ de cada sonda $1 \mathrm{a}, 1 \mathrm{~b}$, 3a, 2a, 2b, 2c (10 $\mu \mathrm{M})$ com volume total de $10 \mu \mathrm{l}$. Para a reação "triplex" foram adicionados $4,4 \mu \mathrm{l}$ do tampão PCR $2 \mathrm{X}, 1,0 \mu \mathrm{l}$

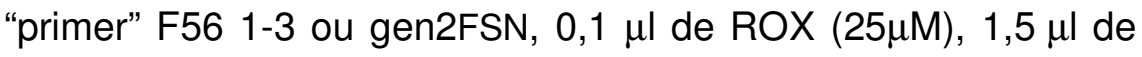
$\mathrm{MgSO}_{4}(50 \mathrm{mM}), 1,0 \mu \mathrm{l}$ de cada sonda concomitantemente para cada set ou seja 1a, 1b e 3a ou 2a, 2b e 2c perfazendo um volume total de $10 \mu \mathrm{l}$. O volume total de $10 \mu \mathrm{l}$ da reação "monoplex" ou "triplex" foi adicionado na tampa ótica específica 
(Applied Biosystems, Foster CA, USA) e fechado cuidadosamente para que o volume de $10 \mu$ presente na tampa não descesse através do tubo. Em seguida, os tubos foram carregados no termociclador 9700 sem fechar a tampa, com proteção contra a luminosidade a $50^{\circ} \mathrm{C}$ por 35 minutos. Após, foram centrifugadas por $2 s$ na centrifuga de tiras Galaxy Mini (VWR International, Korea) e levadas para serem processadas no equipamento 7500 Real time PCR Systems (Applied Biosystems, Foster CA, USA) para os genótipos 1a, 1b e 3a foi utilizado a seguinte condição de ciclagens: $50^{\circ} \mathrm{C}$ por $2 \mathrm{~min}, 95^{\circ} \mathrm{C}$ por $10 \mathrm{~min}, 40$ ciclos de $95^{\circ} \mathrm{C} 15 \mathrm{~s}, 50^{\circ} \mathrm{C} 30 \mathrm{~s}, 60^{\circ} \mathrm{C}$ por $1 \mathrm{~min}$. e para os genótipos $2 \mathrm{a}, 2 \mathrm{~b}$ e $2 \mathrm{c}$ foi utilizado a ciclagem normal do equipamento, ou seja, $50^{\circ} \mathrm{C}$ por $2 \mathrm{~min}, 95^{\circ} \mathrm{C}$ por $10 \mathrm{~min}, 40$ ciclos de $95^{\circ} \mathrm{C} 15 \mathrm{~s}, 60^{\circ} \mathrm{C}$ por $1 \mathrm{~min}$. A velocidade de incremento da rampa de temperatura foi ajustada para similar ao termociclador 9600 a um volume final de $50 \mu$ (Figura 14). 


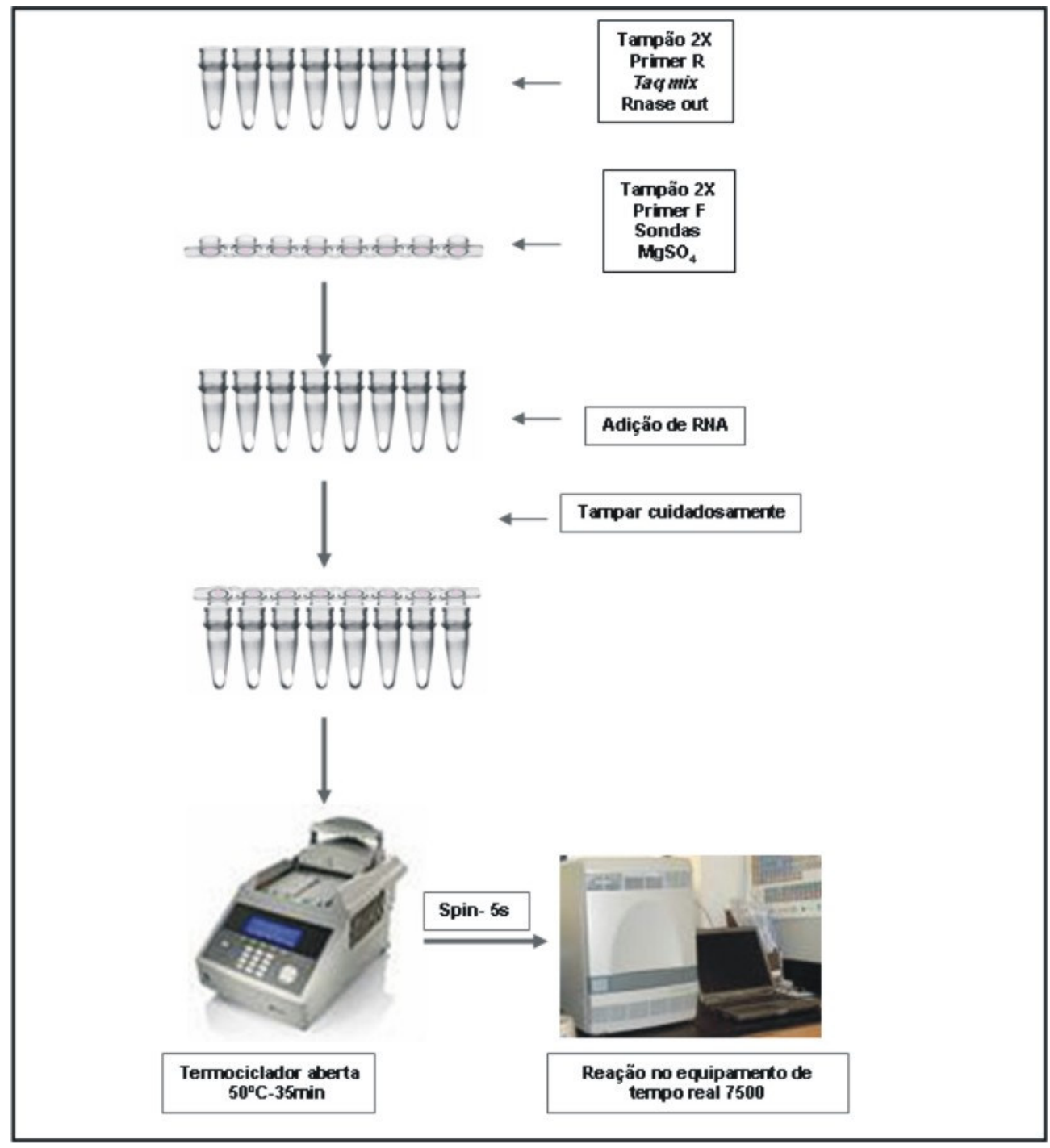

Figura 14 - Representação esquemática da genotipagem por PCR em tempo real "one step" modificada 


\section{TESTES DE VALIDAÇÃO DA PCR EM TEMPO REAL "ONE STEP" MODIFICADO}

Todos os procedimentos para validação dos testes foram realizados conforme a reação "one step" modificado conforme descrito no item 3.12.1-c

\subsection{Intrepretação de resultados}

A amostra foi considerada positiva para determinado genótipo quando a curva de amplificação exponencial cruza o "treshold" num ciclo $\mathrm{Ct}$ $<40$, e os perfis dos sinais emitidos pelos fluoróforos (repórter) e referência passiva (Rox), foram de acordo nos parâmetros dos multicomponentes.

\subsection{Determinação da eficiência da reação "monoplex" e 'triplex" para os diferentes genótipos 1a, 1b, 2b, e 3a}

Amostras de diferentes genótipos (1a, 1b, 2b e 3a) e com carga viral determinada de acordo com o kit - Cobas Amplicor® HCV Test, version 2.0 (Roche, Branchburg, NJ, USA) foram extraídas a partir de $200 \mu \mathrm{l}$ de plasma conforme item 3.9, diluídas de modo seriados de 1:10,1:100,1:1000 e 
1:10000 e realizadas reação em "one-step" modificado conforme item 3.12.1.-c em reação "monoplex" e "triplex" para cálculo da eficiência.

\subsection{Determinação da acurácia do método}

Das 310 amostram anteriormente analisadas, 152 foram submetidos ao seqüenciamento da região NS5B conforme item 3.6 com os "primers" gen1-3 56F e gen1-356R para os genótipos 1 e 3 e com os "primers" gen2FSN e gen2RSN para as amostras do genótipo 2.

\subsection{Análises das seqüências}

As seqüências geradas foram analisadas pelo programa Seqscape (Biosystems, Foster, CA, USA e alinhadas pelo Biedit (132), com a utilização de um painel de referência disponível em: http://hcv.lanl.gov/content/hcvdb/HTML/ToolsOutline.html, Los Alamos National Laboratory. As seqüências obtidas foram comparadas por homologias com o banco de dados do GenBank e determinados os seus genótipos.

\subsection{Análises filogenéticas}

Cento e trinta e oito seqüências deste estudo e quatorze seqüências de diversos genótipos obtidos do GenBank (1a D10749, 1a M62321, 1b AFO54248, 1b D11355, 2a DO00944, 2b D10988, 2b ABO30907, 2c D50409, 3a D28917, 3a D17763, 3b D49374, 4a Y11604, 4a NC009825 out group, 5a Y13184, 6a Y12083). Uma região de 216 nucleotídeos dentro de 
produto de PCR (posição 1223-1438 na região NS5B de acordo com a sequência referência H77.NC_004102) foi utilizada para a análise filogenética. $O$ alinhamento das seqüências foram realizadas pelo programa Clustal $X$ e a árvore foi gerada pelo programa MEGA versão 4.0 (133). Para as distâncias entre os nucleotídeos foi utilizado o modelo $H K Y+l+G$ e o algorítimo de neighbor-joining para a reconstrução das topologia. A robustez da árvore foi testada por análise de bootstraps em 1000 replicatas.

\subsection{Números de acesso ao GenBank}

Cento e cinquenta duas amostras de diferentes genótipos, com seqüências parciais da região NS5B do VHC, seqüenciadas neste estudo foram submetidas ao GenBank e podem ser acessadas através dos números FJ 159697 à FJ 159849.

\subsection{Comparação das genotipagens do VHC realizados pelos métodos LiPA e PCR em tempo real}

Trezentas e dez amostras de diferentes genótipos foram analisadas por PCR em tempo real e comparadas com o método comercial LiPA. 


\subsection{Pesquisa qualitativa e quantitativa do vírus da hepatite C}

Amostras que foram negativas para o teste de genotipagem por PCR em tempo real foram testadas para pesquisa qualitativa do RNA do VHC (Amplicor® Hepatitis C vírus (HCV) Test, version 2.0 - Roche, Branchburg, NJ, USA) e amostras que foram positivas para o RNA qualitativo do VHC foram realizadas a carga viral do RNA do VHC pelo teste Cobas Amplicorß HCV Test, version 2.0 (Roche, Branchburg, NJ, USA)

\subsection{Determinação da sensibilidade analítica do método}

A sensibilidade de teste de genotipagem por PCR em tempo real foi determinada através de uma amostra com quantificação predeterminada do painel internacional OptiQuant ${ }^{\circledR}$ HCV RNA Quantification Panel (Acrometrix, Benicia, CA, USA). Uma amostra do painel com determinação de $5.000 \mathrm{UI} / \mathrm{ml}$ foi diluída com plasma humano negativo para HCV para $1.000 \mathrm{Ul} / \mathrm{ml}, 500 \mathrm{Ul} / \mathrm{ml}$, $250 \mathrm{UI} / \mathrm{ml}$ e $125 \mathrm{UI} / \mathrm{ml}$. Nessas amostras foram realizadas procedimentos de extração do RNA e realizadas genotipagem por tempo real. O limite mínimo de detecção foi determinado pela menor concentração de RNA do VHC produzindo uma taxa de detecção positiva de $90 \%$ ou superior. 


\subsection{Determinação da sensibilidade relativa do método}

A sensibilidade relativa do método para os principais genótipos do VHC foi determinada pela análise de amostras clínicas de indivíduos infectados pelo VHC. As amostras testadas incluíram os genótipos e subtipos do VHC mais freqüentes (1a, 2b e 3a) na população brasileira. $\mathrm{O}$ genótipo 1b foi testado atavés do painel OptiQuant da Acrometrix. Com base nas concentrações iniciais do RNA do VHC, determinadas através do Cobas Amplicor foram preparadas diluições de parâmetro de avaliação final de cada amostra em concentrações finais de aproximadamente $1.000 \mathrm{Ul} / \mathrm{ml}$, $500 \mathrm{Ul} / \mathrm{ml}, 250 \mathrm{Ul} / \mathrm{ml}$ e $125 \mathrm{Ul} / \mathrm{ml}$. Cada concentração foi testada em 8 réplicas. O limite mínimo de detecção foi determinado pela menor concentração de RNA do VHC produzindo uma taxa de detecção positiva de $95 \%$ ou superior.

\subsection{Determinação da reprodutibilidade do método}

Quatro amostras de diferentes genótipos 1a, 1b e 3a foram extraídas em 6 replicatas cada amostra e foram testadas 3 vezes em dias diferentes. As reações foram realizadas em triplicatas $(\mathrm{N}=48)$. 


\subsection{Determinação da especificidade do método}

A especificidade do método foi testada em 53 amostras de plasma coletadas de indivíduos doadores de banco de sangue com sorologia negativa. As amostras foram coletadas com EDTA, submetidos à extração de RNA e genotipadas por PCR em tempo real para as reações "triplex" 1a, 1b, $3 a$ e $2 a, 2 b, 2 c$.

\subsection{Detecção de múltiplos genótipos através da mistura de RNA de diferentes pacientes}

Duas amostras, uma caracterizada como genótipo 1a e outra como genótipo 3a com cargas virais similares, foram diluídas no mesmo teste. As diluições foram de 1:1, 1:5 e 1:10 para o genótipo 1a e vice-versa para o genótipo 3a.

\subsection{Detecção de múltiplos genótipos através de diluições de parâmetro final}

Duas amostras clínicas que foram caracterizadas como mistura de genótipos, uma amostra que apresentou genótipos 1a/1b (419.000 Ul/ml) e outra como 1a/3a $(332.000 \mathrm{Ul} / \mathrm{ml})$ foram testadas através de diluições de 
parâmetro final. Com base nas concentrações iniciais do RNA do VHC determinadas pelo teste Cobas Amplificor version 2.0 (Roche, Branchburg, NJ, USA) foram preparadas diluições de cada amostras até concentrações finais de aproximadamente 1000, 500, 250, $125 \mathrm{UI} / \mathrm{ml}$. Cada uma destas diluições foram testadas em triplicatas e a menor concentração positiva foi testada em 10 vezes.

\subsection{Pesquisa de reação cruzada com genótipos 4 e 5}

Quatro amostras caracterizadas como genótipos 4 e uma amostra do genótipo 5 foram extraídas e genotipadas por PCR em tempo real para as reações "triplex" 1a, 1b, 3a e 2a, 2b, 2c.

\subsection{Pesquisa de reação cruzada com vírus da hepatite A e B}

Dez amostras de pacientes com sorologia positiva para AgHBs e carga viral detectável do DNA do VHB foram testadas para a genotipagem do VHC por PCR em tempo real para as reações "triplex" 1a, 1b, 3a e 2a, 2b, 2c. O DNA do VHB foi detectado conforme protocolo utilizado no LACEN-PR com sondas específicas marcadas com FAM e padronizadas pela curva padrão validada pelo painel de quantificação Optiquant HBV DNA (Acrometrix, CA, USA).

Dez amostras com sorologia positiva para o vírus da hepatite A-VHAIgM e RNA detectável para o VHA conforme técnica previamente descrita 
(134) foram testadas para a genotipagem do VHC por PCR em tempo real para as reações "triplex" 1a, 1b, 3a e 2a, 2b, 2c.

Todas estas amostras foram previamente testadas para detecção do RNA do VHC através do kit - Amplicor® Hepatitis C Virus - HVC - Test, version 2.0 (Roche, Branchburg, NJ, USA), conforme instruções do fabricante.

\subsection{Pesquisa de reação cruzada com o vírus - HIV}

Dez amostras de pacientes com sorologia positiva e carga viral detectável pelo kit HIV-1 RNA 3.0 assay-bDNA (Bayer, Tarrytown, NY USA) para o vírus da Imunodeficiência Adquirida e negativos para a detecção do RNA do VHC testada conforme instruções do fabricante Amplicor® Hepatitis C Vírus - HVC - Test, version 2.0 (Roche, Branchburg, NJ, USA), foram testadas para a genotipagem do VHC por PCR em tempo real para as reações "triplex" 1a, 1b, 3a e 2a, 2b, 2c.

\subsection{Pesquisa de reação cruzada com o vírus da dengue}

Dez amostras de pacientes com PCR positiva para o vírus da dengue (135) e negativas para a detecção do RNA do VHC, testadas conforme instruções do fabricante (Amplicor® Hepatitis C Vírus - HVC - Test, version 2.0)(Roche, Branchburg, NJ, USA), foram submetidas à extração do RNA e testadas para a genotipagem do VHC por PCR em tempo real para as reações "triplex" 1a, 1b, 3a e 2a, 2b, 2c. 
3.31 Algoritmo sugerido para laboratório de saúde pública para a realização da genotipagem do VHC por PCR em tempo real

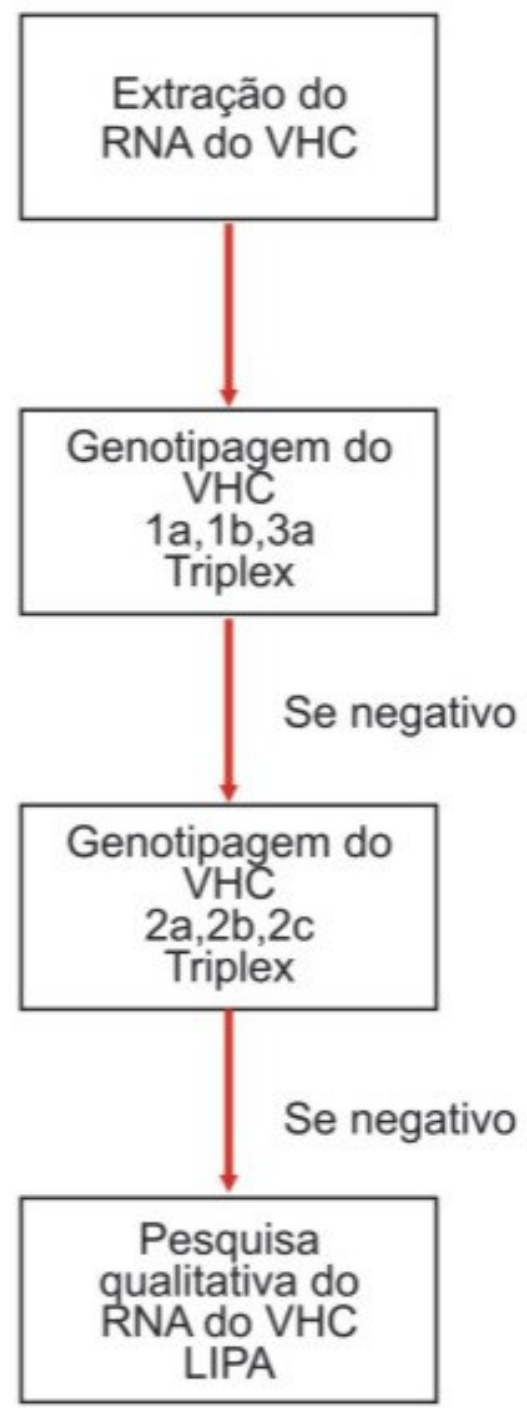




\subsection{Análise estatística}

As análises estatísticas de coeficiente de Kappa (Cohen) entre os métodos foram realizadas no programa $\mathrm{R}$ versão 2.7.0 para Windows. Para o cálculo da concordância foi utilizado o pacote "concord". Assumiu-se uma boa concordância para o coeficiente de Kappa um valor entre 0,61$0,80(136)$. 


\section{RESULTADOS}

\section{SEQÜENCIAMENTO DAS AMOSTRAS PARA DESENHO DE SONDAS E "PRIMERS" PARA GENOTIPAGEM DO VHC POR PCR EM TEMPO REAL}

\subsection{Desenhos dos "primers"}

O par de "primer" NS5B2F/NS5B2R mostrou-se eficiente na amplificação das amostras dos genótipos 1 a 5 . Entretanto, houve resultados falsos negativos em 18\% das amostras que não amplificaram com estes "primers". Dentre estes, seis amostras do genótipo 2 não foram amplificadas por este "primer" e foi necessário utilizar um par de "primer" mais específico para o genótipo 2. O "primer" (GEN2FSN/GEN2RSN) mostrou-se eficiente em amplificar estas amostras. Destas amostras do genótipo 2, cinco amostras foram classificadas através do Blast (Blast National Center for Biotechonology Information: www.ncbi.nim.nih.gov), como genótipo 2c e um genótipo como 2b. Para as amostras classificadas pelo LiPA como infecção mista como 1 e 3, ou em amostras que não foram definidos os subtipos pelo LiPA como 1a/1b e 3a/3b foi utilizada um outro par de "primer" (F56_1-3/R56_1-3). 


\subsection{Padronização da reação da PCR}

Os gradientes de temperaturas realizados para os diferentes pares de "primers" mostraram uma maior eficiência com as seguintes temperaturas NS5B2F/NS5B2R: $60.5^{\circ} \mathrm{C} ; \mathrm{F} \_561-3 / R \_561-3: 54^{\circ} \mathrm{C}$; GEN2FSN/GEN2RSN: $58^{\circ} \mathrm{C}$.

Nas figuras 15, 16, 17 estão apresentados os resultados das amplificações dos diferentes genótipos com os diferentes "primers".

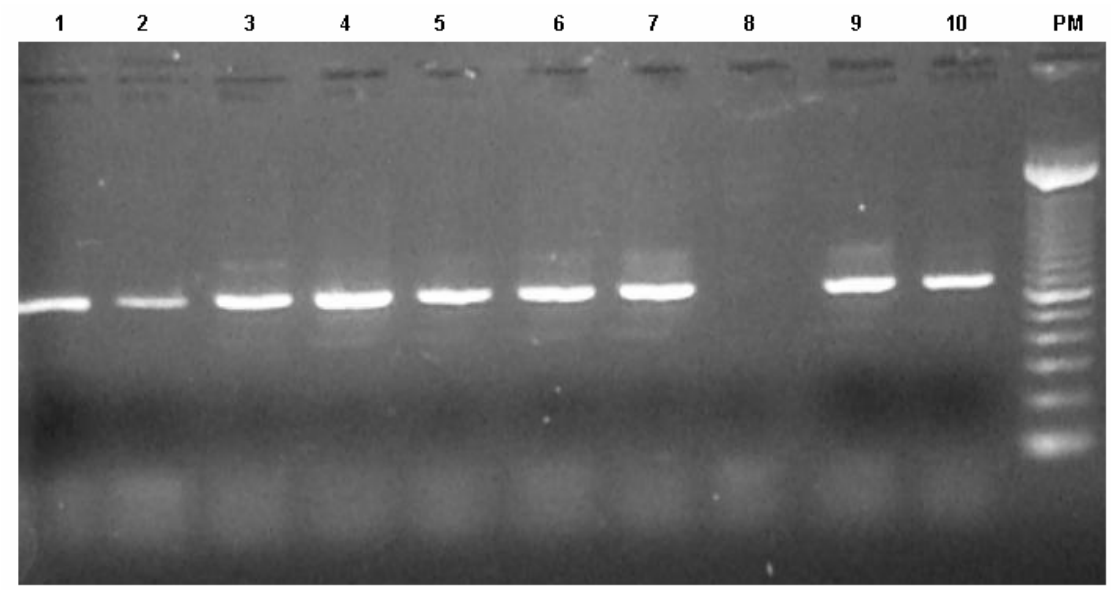

1 à 4 : genótipo 1 b; 5 e 6 genótipo 1 a; 7 genótipo 3a; 8 controle negativo; 9 genótipo $4 ; 10$ genótipo 5; PM marcador de Peso molecular de $100 \mathrm{pb}$

Figura 15 - PCR com "primers" NS5B2F/NS5B2R da região NS5B do VHC que amplificam produto de $688 \mathrm{pb}$ de genótipos de 1 a 5

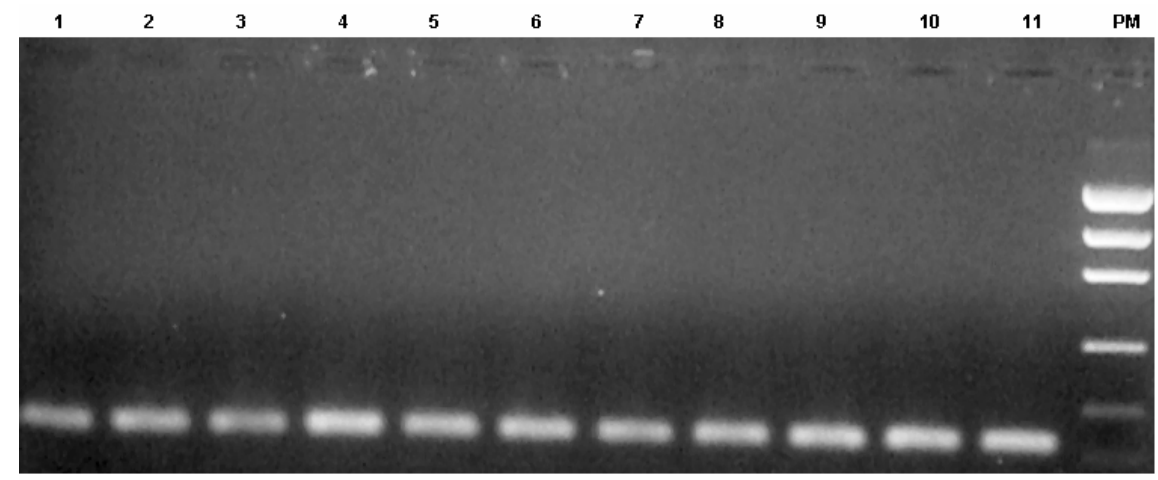

1 á 5 genótipo 2c; 6 á 11 genótipo 2b; PM : peso molecular de 100 pb

Figura 16 - PCR com "primers" GEN2FSN/GEN2RSN da região NS5B do VHC que amplificam produto de 120 pb do genótipo 2 


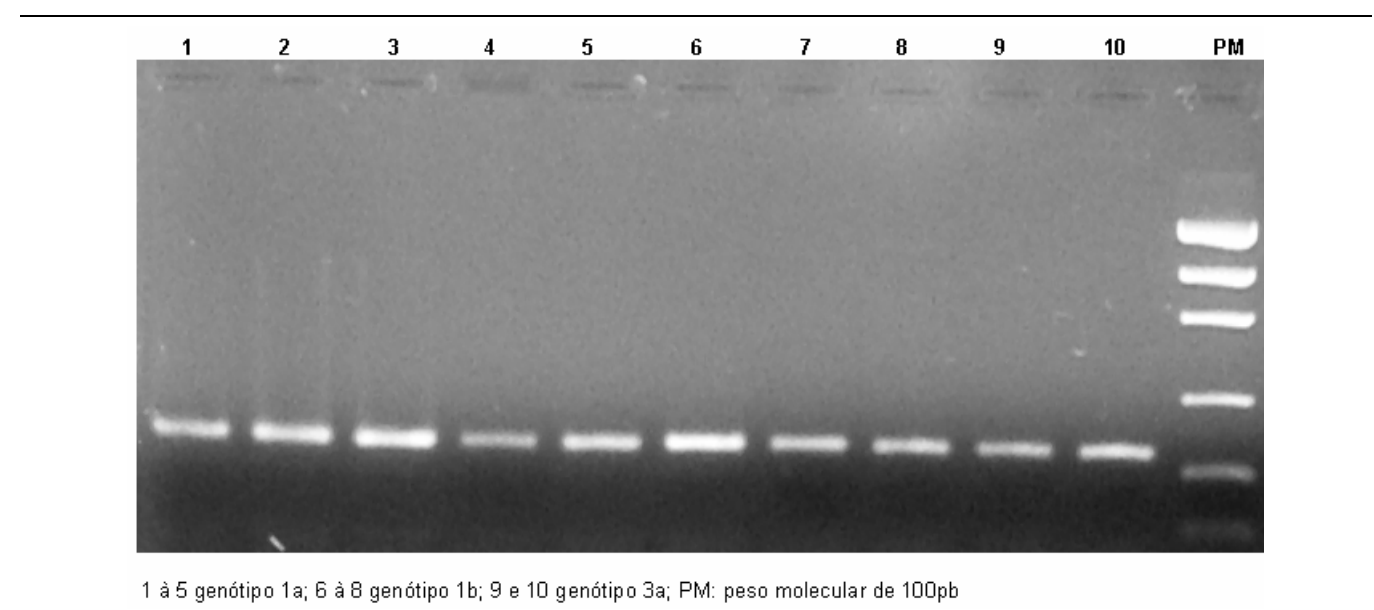

Figura 17 - PCR com "primers" F56_1-3/R56_1-3 da região NS5B do VHC que amplificam produto de $241 \mathrm{pb}$ dos genótipos 1 e 3

\subsection{Comparação dos genótipos do VHC pelos métodos de seqüenciamento da região NS5B e pelo método comercial LiPA (região 5'UTR)}

Os resultados de genotipagem do VHC através do seqüenciamento foram comparadas com o método de LiPA. A comparação dos resultados de genotipagem obtidos pelo seqüenciamento da região NS5B e LiPA não mostrou diferenças na classificação quanto ao tipo (Tabela 5). Houve uma boa concordância entre seqüenciamento e LIPA pelo coeficiente de Kappa $(\kappa=0,6933 p<0,0001)$. Por outro lado, foram encontradas discrepâncias, resultados indefinidos ou resultados incompletos em relação ao subtipo de $60,2 \%$ (44/73) entre os resultados de seqüenciamento e LiPA quando amostras de infecção mista foram excluídas (Tabela 5). Neste caso houve uma concordância apenas moderada $(\kappa=0,4800 p<0,0118)$ quando agrupados os subtipos. Em onze amostras, Lipa não conseguiu discriminar o subtipo 1a, que foi identificada somente como genótipo 1 , com um perfil de 
hibridização nas bandas 3/4/5/6/8 que não discrimina o subtipo 1a ou 1b. Três amostras caracterizadas pelo LiPA como genótipo 1b foram identificadas como genótipo 1a. Cinco amostras foram caracterizadas pelo LiPA como 1a/1b, isto é, LiPA não conseguiu discriminar o subtipo. Após seqüenciamento da região NS5B, três amostras foram caracterizadas como genótipo 1a, uma amostra como $1 \mathrm{~b}$ e uma amostra foi caracterizada somente como genótipo 1 pelo Blast (Blast National Center for Biotechonology Information: www.ncbi.nim.nih.gov), com homologia de 95\% (número de acesso DQ889267-1).

Entre as 15 amostras do genótipo 2b, LiPA conseguiu identificar o subtipo somente em 4 amostras.

Em relação ao genótipo 3, LiPA classificou corretamente todas as amostras como genótipo $3 \mathrm{a}$, e foram posteriormente confirmadas pelo seqüenciamento da região NS5B.

Tabela 5 - Comparação dos resultados de genotipagem obtidos pelo LiPA (5'UTR) e com seqüenciamento da região NS5b do VHC

\begin{tabular}{|c|c|c|c|c|c|c|c|c|c|c|}
\hline \multirow{2}{*}{ LiPA } & \multicolumn{10}{|c|}{ SEQÜENCIAMENTO DA REGIÃO NS5B } \\
\hline & $1 a$ & $1 b$ & 1 & $2 a$ & $2 b$ & $2 c$ & $3 a$ & $4 a$ & $5 a$ & Total \\
\hline 1 & 11 & 1 & & & & & & & & 12 \\
\hline $1 b$ & 3 & $9^{1}$ & & & & & & & & 12 \\
\hline $1 a / 1 b$ & 3 & 1 & 1 & & & & & & & 5 \\
\hline $1 a$ e $3 a$ & 1 & & & & & & 2 & & & 3 \\
\hline 2 & & & & 1 & 11 & 7 & & & & 19 \\
\hline $2 b$ & & & & & $4^{1}$ & & & & & 4 \\
\hline $2 a / 2 c$ & & & & & & 2 & & & & 2 \\
\hline $3 a$ & & & & & & & $13^{1}$ & & & 13 \\
\hline $3 a / 3 b$ & & & & & & & 1 & & & 1 \\
\hline 4 & & & & & & & & 1 & & 1 \\
\hline 5 & & & & & & & & & 1 & 1 \\
\hline Total & 18 & 11 & 1 & 1 & 15 & 9 & 16 & 1 & 1 & 73 \\
\hline
\end{tabular}

${ }^{1}$ Amostras que correlacionaram entre os dois métodos. 
Tabela 6 - Comparação entre LiPA (5'UTR) e seqüenciamento da região NS5B do VHC das amostras com subtipos discordantes, incompletos, indefinidos ou de misturas de genótipos

\begin{tabular}{|c|c|c|c|c|}
\hline \multirow{2}{*}{$\begin{array}{c}\text { QUANTIDADE } \\
\text { DE } \\
\text { AMOSTRAS }\end{array}$} & \multicolumn{3}{|c|}{ LiPA (5'UTR) } & \multirow{2}{*}{$\begin{array}{c}\text { SEQÜEN- } \\
\text { CIAMENTO DA } \\
\text { REGIÃO NS5E }\end{array}$} \\
\hline & $\begin{array}{l}\text { Resultados, } \\
\text { incompletos } \\
\text { indefinidos }\end{array}$ & $\begin{array}{l}\text { Resultados } \\
\text { incorretos }\end{array}$ & $\begin{array}{c}\text { Misturas } \\
\text { de genótipos }\end{array}$ & \\
\hline 11 & 1 & - & & $1 a$ \\
\hline 1 & 1 & - & & $1 b$ \\
\hline 3 & - & $1 b$ & & $1 a$ \\
\hline 2 & $2 a / 2 c$ & & & $2 c$ \\
\hline 3 & $1 a / 1 b$ & & & $1 a$ \\
\hline 1 & $1 a / 1 b$ & & & $1 b$ \\
\hline 1 & $1 a / 1 b$ & & & $1^{1}$ \\
\hline 11 & 2 & - & & $2 b$ \\
\hline 7 & 2 & & & $2 c$ \\
\hline 1 & 2 & - & & $2 a$ \\
\hline 1 & $3 a / 3 b$ & & & $3 a$ \\
\hline 1 & 4 & - & & $4 a$ \\
\hline 1 & 5 & & & $5 a$ \\
\hline 2 & & & 1 e 3 & $3 a$ \\
\hline 1 & & & 1 e 3 & $1 a$ \\
\hline
\end{tabular}

${ }^{1}$ Sem discriminação do subtipo.

\subsection{Determinação de infecção por múltiplos genótipos}

Três amostras mostraram hibridizações nas bandas 1, 2, 3, 4, 5, 13, 14, 15. Pelo perfil de hibridização as bandas 3, 4, 5 são consideradas como genótipo 1 e as bandas 13, 14, e 15 como genótipo 3. Estas amostras foram seqüenciadas na região NS5B, duas amostras foram caracterizadas como genótipo 3a e uma amostra como genótipo 1a. Nenhuma das amostras mostrou infecção mista pelo seqüenciamento da região NS5B (Tabela 6).

\subsection{Artigo submetido}

Os dados de seqüenciamento dessa etapa foram somados ao seqüenciamento posterior realizado para verificar a acurácia do método de 
genotipagem por PCR em tempo real e descrito no artigo "Comparative Evaluation of Hepatitis C Genotyping 5' Untranslated Region "versus" NS5B Region from Brazilian Patients with Chronic Hepatitis C" (Anexo A).

\section{DESENVOLVIMENTO E PADRONIZAÇÃO DA TÉCNICA DE PCR EM TEMPO REAL PARA A GENOTIPAGEM DO VHC}

\subsection{Desenho dos "primers" e sondas}

Os desenhos das sondas e "primers" foram realizados dentro de uma região conservada da região NS5B para os diferentes genótipos do VHC e de acordo com a plataforma "Taqman".

Um único par de "primer" (F56_1-3/R_561-3) foi concebido para amplificar os diferentes genótipos 1a, 1b e 3a e três sondas distintas (1a66, 1b266, 3a66) foram desenhadas para detectar cada um destes genótipos. Para o genótipo 1b (sonda 1b66) e 3a (3a266) foi desenhado uma segunda opção de sonda baseado nas mutações existentes na região das sondas.

\subsection{Realização de matriz de titulação para verificar a concentração ótima de "primers" e sondas}

A realização das matrizes para verificar a melhor concentração de "primers" e sondas foram realizadas em "two step". Primeiramente foi realizada a titulação para o genótipo $3 a$. Verificou-se que o comportamento 
da reação utilizando sonda com concentração final de 200 nM não diferia do comportamento da reação utilizando concentração final de 300 nM. Para os genótipos 1a e 1b foram realizadas somente titulações dos "primers" com concentração final fixa em 200 nM para as sondas. Todas as reações foram realizadas em triplicatas.

Não houve diferença entre os valores dos Cts para as diferentes concentrações de "primers" e sondas. A partir dessa matriz de titulação ficou determinada a concentração de 200 nM para "primers" e sondas. Na tabela 7 está demonstrado a média dos valores de Cts nas diferentes concentrações de "primers" e sondas avaliadas.

Tabela 7 - Matriz dos diferentes genótipos com os valores da média de Cts

\begin{tabular}{|c|c|c|c|}
\hline \multirow{2}{*}{ GENÓTIPO } & \multicolumn{3}{|c|}{ SONDA/"PRIMER" } \\
\hline & $200 \mathrm{nM} / 200 \mathrm{nM}$ & $200 \mathrm{nM} / 600 \mathrm{nM}$ & $200 \mathrm{nM} / 900 \mathrm{nM}$ \\
\hline $1 a$ & Ct 25,38 & Ct 25,26 & Ct 25,25 \\
\hline $1 b$ & Ct 31,70 & Ct 31,89 & Ct 31,34 \\
\hline $3 a$ & Ct 26,42 & Ct 26,93 & Ct 26,64 \\
\hline genótipo & $\begin{array}{l}\text { 300nM/200nM } \\
\text { Sonda/"primer" }\end{array}$ & $\begin{array}{l}\text { 300nM/600nM } \\
\text { Sonda/"primer" }\end{array}$ & $\begin{array}{l}\text { 300nM/900nM } \\
\text { Sonda/"primer" }\end{array}$ \\
\hline $3 a$ & 26,56 & 26,04 & 25,30 \\
\hline
\end{tabular}




\subsection{Padronização da transcrição reversa e amplificação em sistema "one-step" para a genotipagem por PCR em tempo real do VHC}

Foi também objetivo deste trabalho a seleção do sistema de melhor desempenho para a genotipagem do VHC. Foram realizadas diversas modificações em relação a transcrição reversa do VHC. Inicialmente foram realizados testes em relação ao modo de incubação para a reação de transcrição reversa. O primeiro foi realizado conforme o protocolo padrão descrito no equipamento de tempo real (reação "one-step"). Outro protocolo testado consistia de incubação de $55^{\circ} \mathrm{C}$ por 30 minutos no termociclador com a tampa aberta para a reação de transcrição reversa e em seguida transferência da reação para o equipamento de tempo real para os passos de amplificação em tempo real (reação "one-step com modificação na incubação). Por último, foi avaliada a reação denominada "one-step" modificado. Nessa versão, os reativos foram divididos em duas partes. Na primeira parte os reativos como "primer" forward, sondas, $\mathrm{MgSO}_{4}$ foram adicionados à tampa ótica dos tubos de reação durante a preparação do teste. Em seguida, a transcrição reversa foi realizada no termociclador com a tampa deste aberto. Após o término da reação de transcrição reversa foi realizado "spin" para adição dos reativos da tampa ao meio reacional e em seguida os tubos foram colocados no equipamento de tempo real para os passos de amplificação. Finalmente para uma comparação global entre os diferentes métodos escolheu-se 6 amostras de plasmas com genotipagem previamente conhecida. As reações foram realizadas em duplicata em reação "monoplex", isto é, tubos separados para os genótipos 1a, 1b e 3a. Realizou-se concomitantemente reações em "duplex" para 3 amostras, isto é, 
foram colocadas sondas 1a e 1b no mesmo tubo e processadas as reações. $\mathrm{Na}$ tabela 8 estão relacionados os Cts obtidos para cada método com as diferentes amostras para cada genótipo do VHC.

Através da análise dos Cts de cada método verificou-se que o método "one-step" modificado apresentou melhor eficiência frente aos outros. Apesar do $\mathrm{n}$ pequeno a reação em "duplex" para duas amostras deram Cts abaixo do que na reação em "monoplex".

Tabela 8 - Cts de diferentes protocolos "one-step" "monoplex" e "duplex"

\begin{tabular}{c|c|c|c|c}
\hline AMOSTRAS & "ONE-STEP" & $\begin{array}{c}\text { "ONE-STEP" } \\
55^{\circ} \mathrm{C} \\
30 \mathrm{~min}\end{array}$ & $\begin{array}{c}\text { "ONE-STEP" } \\
\text { MODIFICADO }\end{array}$ & $\begin{array}{c}\text { "ONE-STEP"- } \\
\text { MODIFICADO } \\
\text { "DUPLEX" }\end{array}$ \\
\hline 2631-gen 1a & 27,52 & 29,01 & 24,43 & 22,79 \\
264 gen 1a & 35,94 & 39,32 & 32,85 & 29,71 \\
2671 gen 3a & 32,90 & 37,48 & 30,62 & NR \\
2656 gen 3a & 32,91 & 33,63 & 26,73 & NR \\
\hline
\end{tabular}

\subsection{Comparação das sondas $1 \mathrm{~b} 266$ e 1b66; 3a66 e 3a266}

Sete amostras do genótipo $1 \mathrm{~b}$ foram comparadas com sondas $1 \mathrm{~b} 66$ e 1b266. Com a sonda 1b66, quatro amostras não apresentaram sinais de fluorescência e a média dos Cts foi de 28,66, por outro lado com a sonda 1 b266 em seis amostras foram detectados sinais de fluorescência e somente uma amostra não apresentou nenhum sinal de fluorescência. A média dos Cts obtidos com a sonda 1 b266 foi de 28,47 .

Do mesmo modo, sete amostras do genótipo 3a foram comparadas com sondas 3a66 e 3a266. Com a sonda 3a66, uma amostra não apresentou sinal de fluorescência e a média dos Cts foi de 23,74 , por outro lado com a 
sonda 3a266, duas amostras não apresentaram nenhum sinal de fluorescência. A média dos Cts obtidos com a sonda $3 a 266$ foi de 32,79. Através destes resultados foi padronizado a detecção das amostras para o genótipo 1b com a sonda 1 b266 e para o genótipo 3a com a sonda $3 a 66$.

\subsection{Determinação da eficiência da reação para os diferentes genótipos}

1a, 1b, 2b e 3a quanto aos sistemas "monoplex" e "triplex"

Verificou-se que a eficiência da reação em "triplex", ou seja, quando as sondas 1a, 1b e 3a são colocadas na mesma reação apresentou uma eficiência maior para os quatro genótipos do que quando realizada em sistema "monoplex" conforme Tabela 9.

Tabela 9 - Eficiência das reações para os diferentes genótipos em sistemas "monoplex" e "triplex"

\begin{tabular}{c|c|c|c|c}
\hline \multirow{2}{*}{} & \multicolumn{4}{|c}{ EFICIÊNCIA DA REAÇÃO } \\
\cline { 2 - 5 } & $1 \mathrm{a}$ & $1 \mathrm{~b}$ & $3 \mathrm{a}$ & $2 \mathrm{~b}$ \\
\hline "Monoplex" & $\mathrm{NC}$ & $74 \%$ & $59 \%$ & NR \\
"Triplex" & $105 \%$ & $103 \%$ & $98 \%$ & $106 \%$ \\
\hline NOTA: NC: não foi possível calcular; NR: não realizado. \\
\hline
\end{tabular}

\section{TESTES DE VALIDAÇÃO DA GENOTIPAGEM POR PCR EM TEMPO REAL EM SISTEMA "ONE-STEP" MODIFICADO}




\subsection{Determinação da acurácia o método de genotipagem por PCR em tempo real}

Foi realizado o seqüenciamento parcial da região NS5B de cento e cinqüenta e duas amostras e houve correlação de $100 \%$ com o método de PCR em tempo real quando foram caracterizadas somente com uma única sonda. Seis amostras foram detectadas por duas sondas concomitantemente pelo método de tempo real e classificados somente como um único genótipo no seqüenciamento. Cinco amostras foram genotipadas com as sondas para os genótipos 1a e 1b e tipadas pelo seqüenciamento como $1 \mathrm{~b}$ enquanto que uma amostra foi detectada com as sondas 1a e 3a e caracterizada pelo seqüenciamento com 1a. A Tabela 10 mostra a relação das amostras seqüenciadas e genotipadas por PCR em tempo real. Houve uma boa concordância entre seqüenciamento e PCR em tempo real pelo coeficiente de Kappa $(\kappa=0,6222 ; p=0,0020)$ quando agrupados os tipos e subtipos.

Tabela 10 - Comparação dos métodos de seqüenciamento e PCR em tempo real para a genotipagem do VHC

\begin{tabular}{|c|c|c|c|c|c|c|c|}
\hline \multirow{2}{*}{$\begin{array}{c}\text { TEMPO } \\
\text { REAL (NS5B) }\end{array}$} & \multicolumn{7}{|c|}{ SEQÜENCIAMENTO DO VHC (NS5B) } \\
\hline & $1 a$ & $1 b$ & $2 a$ & $2 b$ & $2 c$ & 3a & TOTAL \\
\hline $1 \mathrm{a}$ & 51 & & & & & & 51 \\
\hline $1 b$ & & 48 & & & & & 48 \\
\hline $1 a / 1 b$ & & 5 & & & & & 5 \\
\hline $1 \mathrm{a} / 3 \mathrm{a}$ & 1 & & & & & & 1 \\
\hline $2 a$ & & & 1 & & & & 1 \\
\hline $2 b$ & & & & 13 & & & 13 \\
\hline $2 c$ & & & & & 2 & & 2 \\
\hline $3 a$ & & & & & & 31 & 31 \\
\hline TOTAL & 52 & 53 & 1 & 13 & 2 & 31 & 152 \\
\hline
\end{tabular}




\subsection{Análises Filogenéticas}

Não houve discrepâncias entre os resultados dos seqüenciamentos realizados através homologia pelo Blast $\mathrm{e}$ as análises filogenéticas realizadas em 138 amostras. A figura 18 mostra a árvore com os diferentes genótipos.

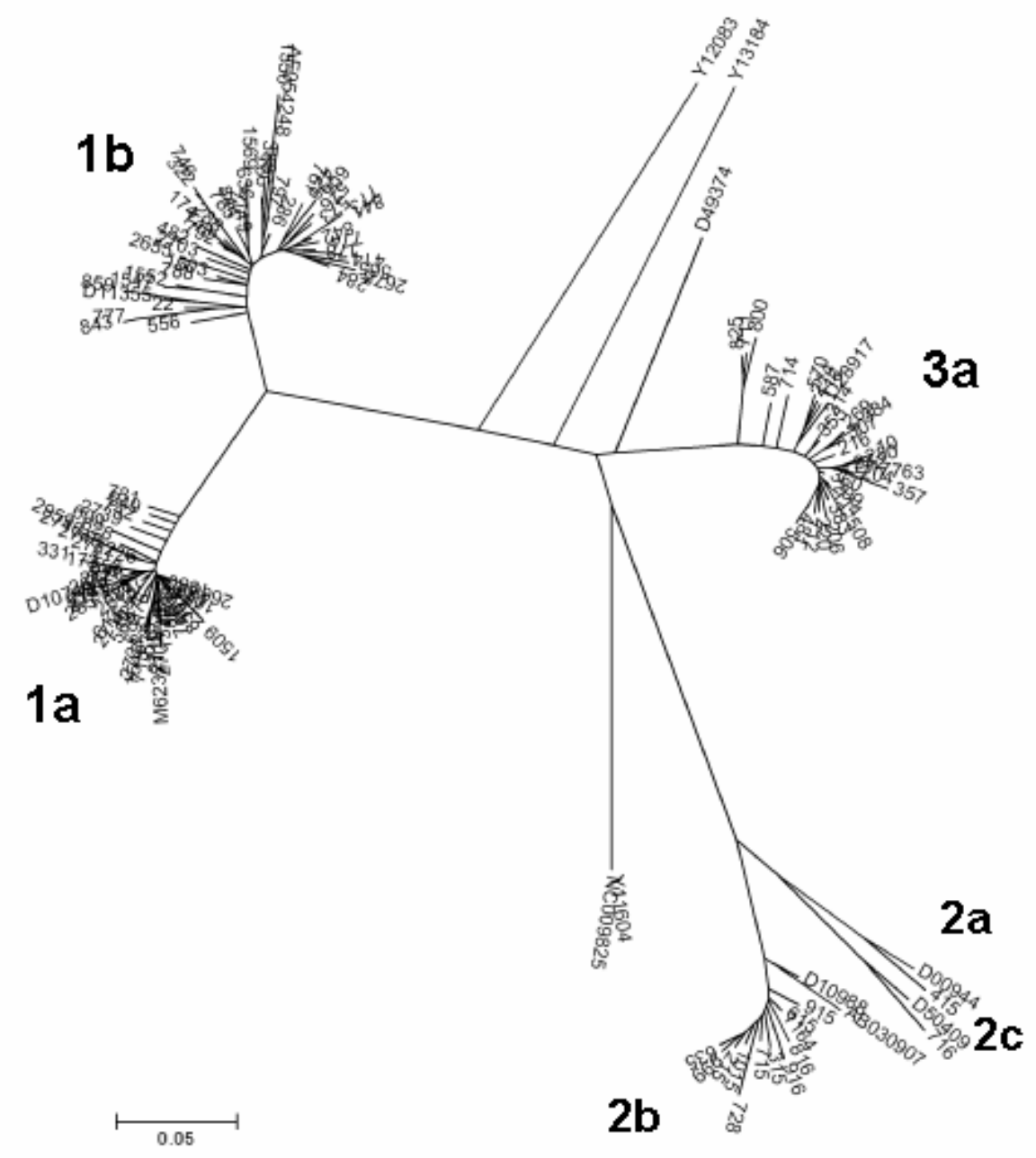

Figura 18. Árvore filogenética construída pelo método Neighbor-Joining, enraizada, de 150 seqüências (138 seqüências deste estudo e 14 com seqüências referencias obtidas do GenBank) da região NS5B com 216 pb; posição 1223-1438 na região NS5B de acordo com a seqüência referencia H77.NC_004102 


\subsection{Genotipagem do VHC por PCR em tempo real}

Foram selecionadas trezentos e dezenove amostras de plasmas de pacientes com genotipagem previamente determinada pelo LiPA. Pelo fato que nas amostras coletadas na Faculdade de Medicina da USP a pesquisa de genotipagem por PCR em tempo real não foi realizada nas mesmas amostras de plasma em que foi realizada a genotipagem pelo LiPA, nove amostras que foram utilizadas nesta pesquisa não tinham RNA do VHC detectável. Estas amostras foram excluídas das análises. Trezentos e dez amostras apresentaram RNA do VHC detectável (Figura 19).

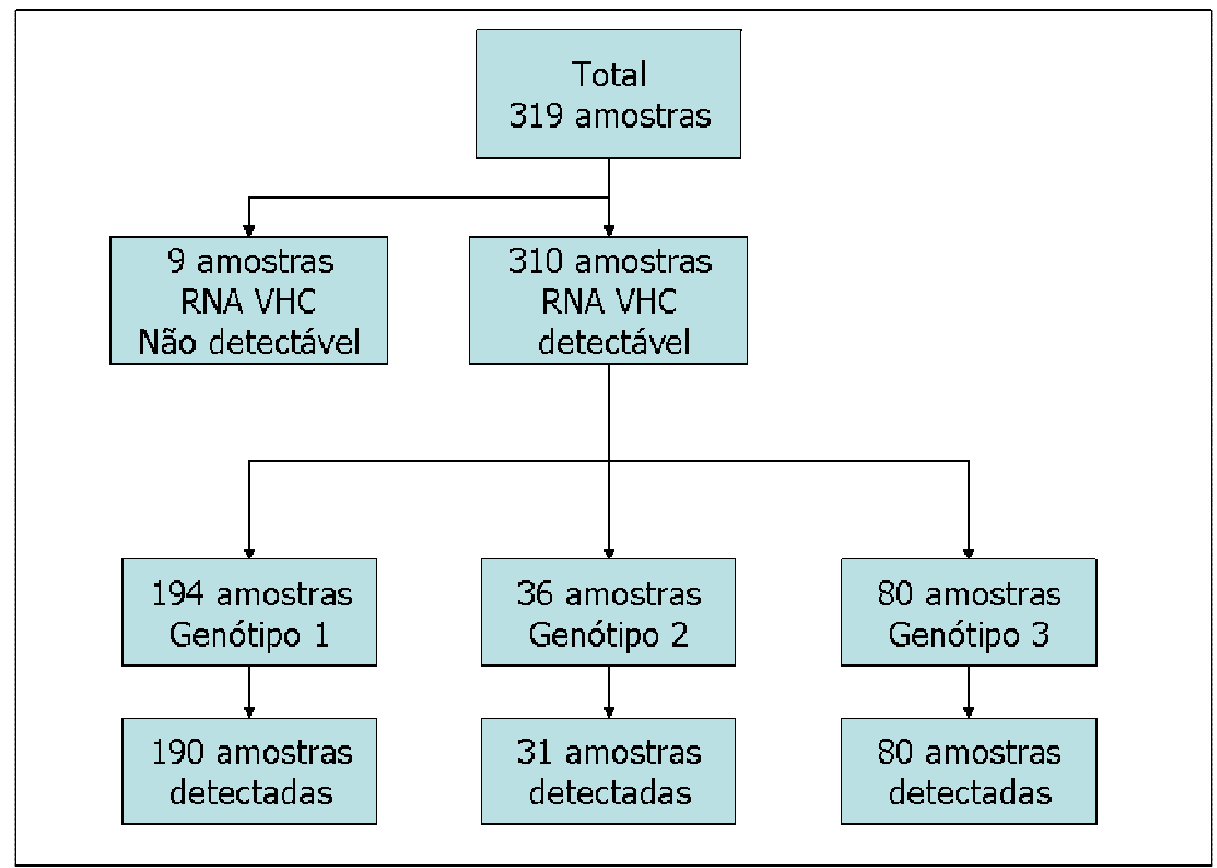

Figura 19 - Fluxograma das amostras genotipadas por PCR em tempo real

Através do método de genotipagem por PCR em tempo real foi possível genotipar em 97,93\% (190/194) das amostras do genótipo 1. A média dos valores dos Cts para as amostras que foram genotipadas pelo método de 
PCR em tempo real para o genótipo 1a foram de 26,43 e para o genótipo 1b de 27,24 . Entre as oitenta nove amostras genotipadas como $1 \mathrm{~b}$ pelo tempo real, duas amostras foram identificadas com a segunda opção de sonda (1b66). Foram realizadas as determinações das cargas virais das 4 amostras do genótipo 1 cujos genótipos não foram detectados por PCR em tempo real. Destas, 2 apresentaram carga viral do VHC acima de $700.000 \mathrm{UI} / \mathrm{ml}$, uma amostra apresentou resultado de $133.000 \mathrm{UI} / \mathrm{ml}$ e outra de $1.280 \mathrm{UI} / \mathrm{ml}$. Para essas quatro amostras foram novamente realizadas reações de PCR com "primers" para seqüenciamento parcial da região NS5B. Três amostras não apresentaram amplificações e somente uma amostra foi amplificada e seqüenciada. No seqüenciamento dessa amostra verificou-se que ocorreram 2 mutações na região da sonda para o genótipo 1a. Em uma dela ocorreu a troca de $\mathrm{T} \rightarrow \mathrm{C}$ e outra de $\mathrm{A} \rightarrow \mathrm{G}$. A figura 20 mostra as mutações ocorridas nesta amostra através da figura do programa seqscape-Applied Biosystems.

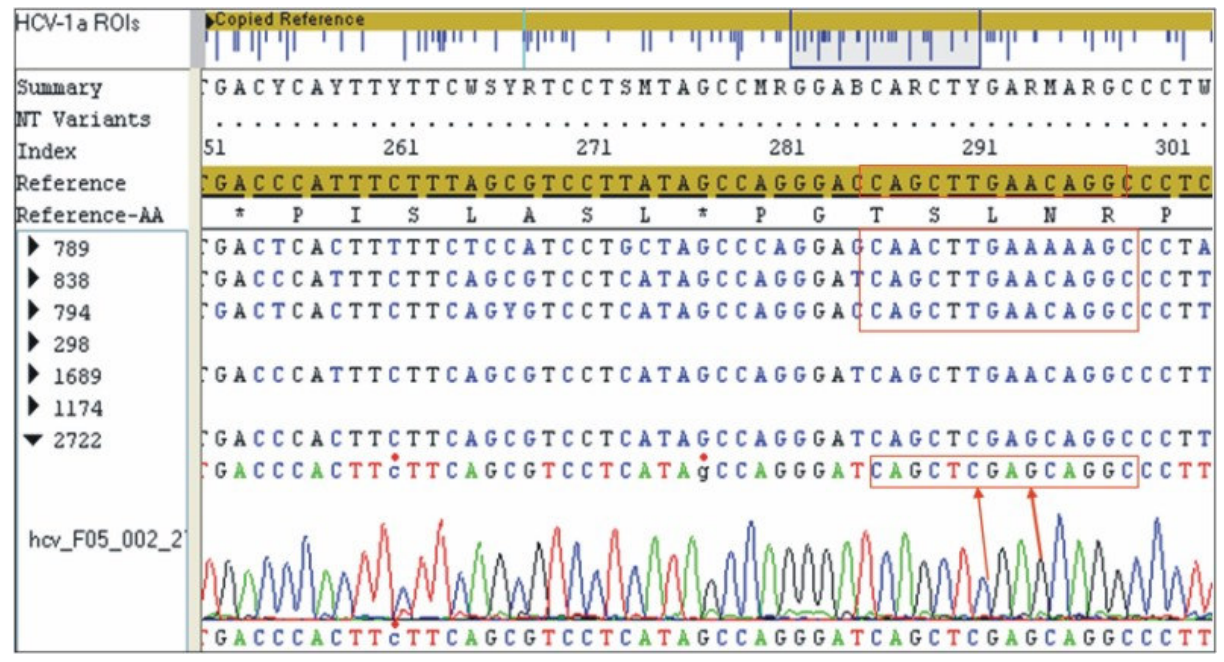

Figura 20 - Seqüências geradas através do programa Secscape. As flechas em vermelho mostram as 2 mutações que ocorreram na região das sondas 
Em relação ao genótipo 2, trinta e seis amostras foram analisadas. O método de genotipagem por PCR em tempo real conseguiu tipar $86,11 \%$ (31/36) das amostras do genótipo 2. A média dos valores dos Cts para as amostras que foram genotipadas pelo método de PCR em tempo real para o genótipo 2 foi 25,83. Das 5 amostras não genotipadas por PCR em tempo real foi realizado a carga viral em 3 amostras. Destas, uma amostra apresentou uma carga viral de $2.250 \mathrm{Ul} / \mathrm{ml}$, duas amostras apresentaram uma carga viral acima de $700.000 \mathrm{UI} / \mathrm{ml}$, quando realizadas pelo método Cobas Amplicor. Para essas três amostras foram novamente realizadas reações de PCR com "primers" da região NS5B para seqüenciamento parcial da região NS5B. Somente uma amostra com carga viral de $2.250 \mathrm{UI} / \mathrm{ml}$ apresentou uma amplificação fraca, mas insuficiente para gerar uma sequência adequada para verificar as mutações. Duas amostras não possuíam quantidade suficiente de plasma para realizar a carga viral e a PCR da região NS5B.

Paralelamente, o método de genotipagem por PCR em tempo real conseguiu genotipar $100 \%$ das amostras (80/80) do genótipo 3. A média dos valores dos Cts para as amostras que foram genotipadas pelo método de PCR em tempo real para o genótipo 3 foram de 26,34. Na Figura 21 está apresentado o gráfico de amplificação dos diferentes genótipos do VHC. 

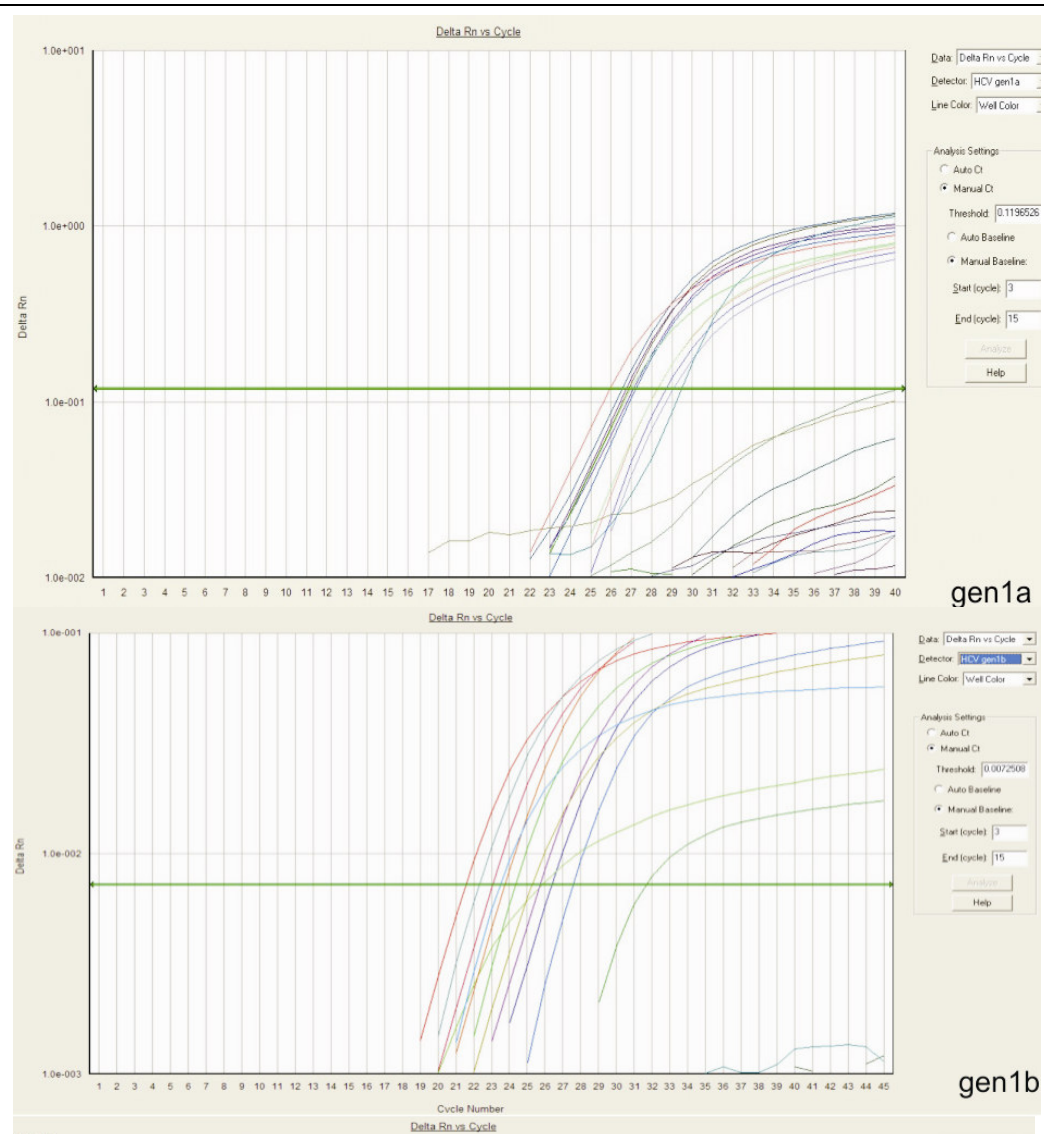

gen1a

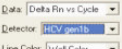

nnersismar

a woc

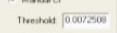

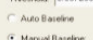

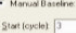

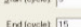

$+$

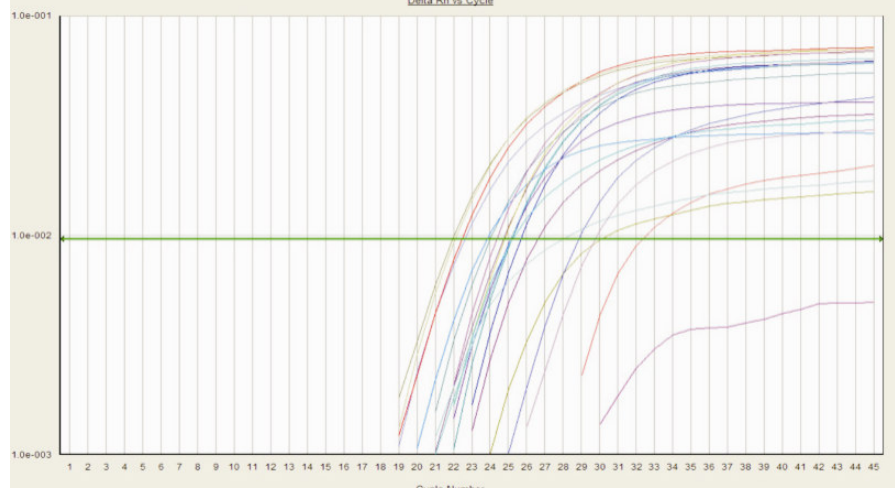

gen1b

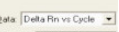

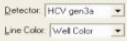

natin sement

- memasa

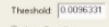

casones

“

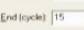

nto

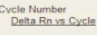

gen3a

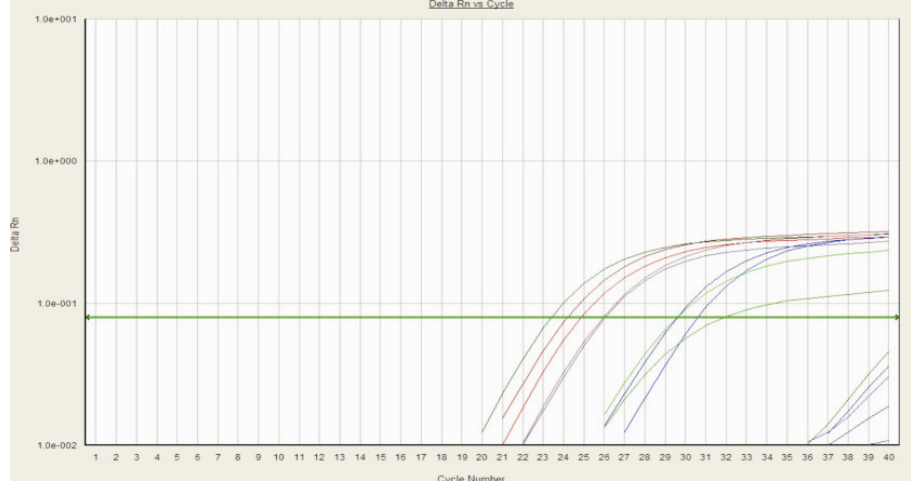

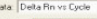

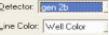

ansus semon

- Mosusa

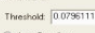

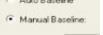

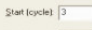

trationt 15

Heo

Figura 21 - Amplificação dos diferentes genótipos por PCR em tempo real 


\subsection{Comparação da genotipagem do VHC pelos métodos LiPA e PCR em tempo real}

Mediante a comparação dos métodos de LiPA e PCR em tempo real não houve resultados discordantes em relação ao tipo entre as trezentos e dez amostras. Há uma boa concordância entre LiPA e PCR em tempo real quando agrupamos somente o tipo pelo coeficiente de Kappa $(\kappa=0,6933$ $(\mathrm{p}<0,0001)$. Na Tabela 11 estão apresentadas todas as amostras genotipadas por LiPA e PCR em tempo real.

Em relação aos subtipos 25,48\% (79/310) das amostras apresentaram resultados incompletos, discordantes ou indefinidos pelo método LiPA quando comparados com o método de genotipagem por PCR em tempo real. Destas, sessenta e quatro amostras (64/79) foram seqüenciadas e confirmaram os resultados da genotipagem por PCR em tempo real. Quando agrupamos os tipos e subtipos entre os métodos de LiPA e genotipagem por PCR em tempo real há uma fraca concordância entre os métodos pelo coeficiente de Kappa $(\kappa=0,1111 ; p=0,2218)$.

LiPA não conseguiu identificar os subtipos para o genótipo 1 em 22,63\% (43/190). O método LiPA também não conseguiu definir o subtipo em oito amostras que foram liberadas como $1 \mathrm{a} / 1 \mathrm{~b}$. Destas, seis amostras foram detectadas com sondas 1a e duas amostras foram detectadas com sondas $1 \mathrm{~b}$ pelo método de genotipagem por PCR em tempo real. Em sete amostras LiPA identificou como genótipo 1b e foi posteriormente identificado como 1a pelo método de genotipagem em tempo real. 
Em relação ao genótipo 2, 61,29\%(19/31) não foram subtipadas corretamente pelo LiPA. Quinze amostras do genótipo 2b foram identificadas sem o subtipo. Na Tabela 12 mostra a relação dos números de amostras discordantes, incompleto ou indefinidos quando comparados os dois métodos.

Tabela 11 - Comparação dos métodos de genotipagem por PCR em tempo real e LiPA

\begin{tabular}{|c|c|c|c|c|c|c|c|c|c|c|}
\hline \multirow{2}{*}{$\begin{array}{c}\text { LiPA } \\
\text { (5'UTR) }\end{array}$} & \multicolumn{10}{|c|}{ GENOTIPAGEM POR TEMPO REAL (NS5B) } \\
\hline & $1 \mathrm{a}$ & $1 b$ & $1 \mathrm{a} / 3 \mathrm{a}$ & $1 \mathrm{a} / 1 \mathrm{~b}$ & $2 a$ & $2 b$ & 2c & 3a & $\begin{array}{c}\text { Nega- } \\
\text { tivo }\end{array}$ & TOTAL \\
\hline 1 & 35 & 7 & & 2 & & & & & 1 & 45 \\
\hline $1 a$ & $47^{1}$ & 5 & & & & & & & & 52 \\
\hline $1 b$ & 7 & $75^{1}$ & 1 & 3 & & & & & 3 & 89 \\
\hline $1 \mathrm{a} / 1 \mathrm{~b}$ & 6 & 2 & & & & & & & & 8 \\
\hline 2 & & & & & 1 & 14 & & & 4 & 19 \\
\hline $2 a$ & & & & & & & 3 & & 1 & 4 \\
\hline $2 b$ & & & & & & $13^{1}$ & & & & 13 \\
\hline $3 a$ & & & & & & & & $80^{1}$ & & 80 \\
\hline TOTAL & 95 & 89 & 1 & 5 & 1 & 27 & 3 & 80 & 9 & 310 \\
\hline
\end{tabular}

${ }^{1}$ Número de amostras que correlacionaram entre os dois métodos.

Tabela 12 - Números de amostras com subtipos discordantes, indefinidos ou resultados incompletos pelo LiPA (5'UTR) quando comparados com genotipagem por PCR em tempo real da região NS5B do VHC

\begin{tabular}{|c|c|c|c|}
\hline \multirow{2}{*}{$\begin{array}{c}\text { QUANTIDADE DE } \\
\text { AMOSTRAS } \\
\text { LiPA (5'UTR) }\end{array}$} & \multicolumn{2}{|c|}{ LiPA (5'UTR) } & \multirow{2}{*}{$\begin{array}{c}\text { GENOTIPAGEM } \\
\text { POR PCR EM } \\
\text { TEMPO REAL } \\
\text { (NS5B) }\end{array}$} \\
\hline & $\begin{array}{l}\text { Resultados } \\
\text { incompletos }^{1}\end{array}$ & $\begin{array}{l}\text { Resultados } \\
\text { discordantes ou } \\
\text { indefinidos }\end{array}$ & \\
\hline 35 & 1 & - & $1 a$ \\
\hline 4 & - & $1 a$ & $1 b$ \\
\hline 6 & 1 & - & $1 b$ \\
\hline 7 & - & $1 b$ & $1 a$ \\
\hline 6 & - & $1 a / 1 b$ & $1 a$ \\
\hline 2 & - & $1 a / 1 b$ & $1 b$ \\
\hline 1 & 2 & - & $2 c$ \\
\hline 2 & - & $2 a$ & $2 c$ \\
\hline 1 & & $2 a / 2 c$ & $2 c$ \\
\hline 15 & 2 & - & $2 b$ \\
\hline TOTAL: 79 & & & \\
\hline
\end{tabular}

\footnotetext{
${ }^{1}$ Sem discriminação dos subtipos.
} 


\subsection{Identificação de múltiplos genótipos pelo método de genotipagem por PCR em tempo real}

Cinco amostras caracterizadas como genótipo 1 pelo LiPA foram detectadas pelo tempo real com sondas $1 \mathrm{a}$ e $1 \mathrm{~b}$ concomitantemente. Do mesmo modo uma única amostra foi caracterizada com as sondas dos genótipos 1a e 3a. O genótipo 1a foi detectado com Ct de 22,18 e o genótipo 3a com Ct de 34,80. A Tabela 13 mostra os diferentes Cts que cada uma das sondas 1a, 1b e 3a amplificaram na detecção de múltiplos genótipos.

Tabela 13 - Cts das diferentes sondas nas amostras que deram misturas de genótipos por genotipagem por PCR em tempo real do VHC

\begin{tabular}{c|c|c|c|c}
\hline \multirow{2}{*}{ AMOSTRAS } & \multirow{3}{*}{ LiPA } & \multicolumn{3}{|c}{ GENOTIPAGEM POR PCR EM TEMPO REAL } \\
\cline { 3 - 5 } & & \multicolumn{3}{|c}{ Cts } \\
\cline { 3 - 5 } & & $1 \mathrm{a}$ & $1 \mathrm{~b}$ & $3 \mathrm{a}$ \\
\hline 1 & 1 & 22,35 & 32,78 & - \\
2 & 1 & 27,59 & 25,44 & - \\
3 & $1 \mathrm{~b}$ & 36,81 & 31,83 & - \\
4 & $1 \mathrm{~b}$ & 33,23 & 28,95 & - \\
5 & $1 \mathrm{~b}$ & 30,25 & 28,37 & - \\
6 & $1 \mathrm{~b}$ & 22,19 & - & 34,80 \\
\hline
\end{tabular}

\subsection{Detecção de múltiplos genótipos através de diluição em parâmetro final}

Foram selecionadas duas amostras para a realização de detecção de múltiplos genótipos através de diluição de parâmetro final. Uma amostra com detecção para os genótipos 1a/1b e outra para 1a/3a. Foram possíveis 
detectar a mistura dos dois genótipos 1a/1b na concentração de $250 \mathrm{UI} / \mathrm{ml}$ em 7 replicatas. Em 3 replicatas não foram possíveis detectar o genótipo 1a. Por outro lado, em 10 replicatas na concentração do $250 \mathrm{UI} / \mathrm{ml}$ a mistura dos genótipos 1a e 3a foram detectados em 4 replicatas. Em quatro replicatas não foram detectados o genótipo 3a e em 2 replicatas o genótipo 1 a.

\subsection{Detecção de múltiplos genótipos através da mistura de RNA de diferentes pacientes}

Foram realizados procedimentos de extração de RNA de 2 amostras uma do genótipo 1a com carga viral de $550.000 \mathrm{Ul} / \mathrm{ml}$ e uma do genótipo 3a com carga viral de $559.000 \mathrm{Ul} / \mathrm{ml}$. Essas amostras foram misturadas nas proporções de 1:1, 1:5 e 1:10 a fim de simular in vitro o comportamento do método de genotipagem por PCR em tempo real frente a amostras com infecção mista. Foram detectadas na reação "triplex" os genótipos 1a e 3a em todas as diluições na relação de 1:1, 1:5 e 1:10 tanto para o genótipo 1a e 3a e vice-versa.

\subsection{Determinação da sensibilidade analítica}

O limite de detecção foi determinado pela menor concentração de VHC capaz de produzir uma taxa de detecção positiva de $90 \%$ ou superior nas replicatas realizadas. A amostra do painel da Acrometrix foi determinada como 
genótipo 1b. O ponto com a carga viral de $5.000 \mathrm{Ul} / \mathrm{ml}$ do painel foi diluído em $1000 \mathrm{Ul} / \mathrm{ml}, 500 \mathrm{UI} / \mathrm{ml}, 250 \mathrm{Ul} / \mathrm{ml}$ e $125 \mathrm{Ul} / \mathrm{ml}$ e realizado a reação de genotipagem por PCR em tempo real. A diluição de $250 \mathrm{UI} / \mathrm{ml}$ foi o último ponto detectado. Á partir dessa diluição, o teste foi realizado em 24 réplicas, sendo que em 22 réplicas houve detecção positiva. Foi determinado um limite de detecção de $90 \%$ a $250 \mathrm{UI} / \mathrm{ml}$ para plasma.

\subsection{Determinação da sensibilidade relativa}

O limite de detecção foi determinado pela menor concentração de VHC capaz de produzir uma taxa de detecção positiva de $95 \%$ ou superior nas 8 replicatas realizadas de cada genótipo pesquisado. Para o genótipo 1a a sensibilidade relativa ficou determinada em $500 \mathrm{UI} / \mathrm{ml}$, genótipo $2 b$ em 250 $\mathrm{Ul} / \mathrm{ml}$ e para o genótipo 3a em $125 \mathrm{Ul} / \mathrm{ml}$.

\subsection{Determinação da reprodutibilidade do método}

O coeficiente de variação intra ensaio para o genótipo 3a realizado em três dias diferentes (N:48) foi de 2,67\% com média de Cts de 27,49+/$0.73(95 \% \mathrm{IC})$, para o genótipo 1b (n:48) foi de 6,25\% com média de Cts de 26,54 +/- 1,66 (95\%lC) e para o genótipo 1a (N: 48) o coeficiente de variação foi de 6,40\% com média de Cts de 27,65+/-1.73 (95\%IC). 


\subsection{Determinação da especificidade do método de genotipagem por PCR em tempo real}

As reações "triplex" para a genotipagem do VHC por PCR em tempo real para os genótipos (1a, 1b e 3a) e (2a, 2b e 2c) não apresentaram nenhuma reação cruzada com as 53 amostras selecionadas do banco de sangue.

\subsection{Pesquisa de reação cruzada com genótipos 4 e 5}

Foram realizados testes de genotipagem por PCR em tempo real com sondas (1a,1b e 3a) e (2a,2b e 2c) de uma amostra do genótipo 5 e quatro amostras do genótipo 4. Não houve reações cruzadas com estas sondas para os genótipos 4 e 5 . O genótipo 6 não foi testado pelo fato de não termos nenhuma amostra identificada como 6 em nossa casuística. Paralelamente foram testadas genótipos 1 e 3 com sondas do genótipo 2 e vice-versa. Não houve detecção cruzada em nenhuma das amostras.

\subsection{Pesquisa de reação cruzada com hepatite viral não C}

A especificidade do teste genotipagem do VHC por PCR em tempo real foi avaliada para detectar uma possível reatividade cruzada frente a outros vírus de hepatite (VHB e VHA). Dez amostras infectadas com cada vírus VHB e VHA e negativas para o RNA do VHC foram testadas frente à 
reação "triplex" e nenhuma das amostras apresentou detecção para os genótipos do VHC.

\subsection{Pesquisa de reação cruzada com o vírus HIV e o vírus da dengue}

Dez amostras de pacientes com infecção pelo HIV e dez amostras de pacientes com infecção pela dengue foram testadas frente ao teste de genotipagem do VHC. Todas as amostras eram RNA do VHC negativas. Nenhuma amostra mostrou reação cruzada frente ao teste de genotipagem do VHC.

\subsection{Custo da reação de genotipagem por PCR em tempo real}

Esses valores foram tomados nas referidas empresas no mês de maio de 2008 ( Tabela 14).

Tabela 14 - Valores por reação para cada teste de genotipagem por PCR em tempo real

\begin{tabular}{|c|c|c|c|}
\hline \multirow{2}{*}{ REAGENTE OU CONSUMÍVEIS } & \multicolumn{3}{|c|}{ VALOR (R\$) } \\
\hline & Total & Unitário & Por reação \\
\hline Extração do RNA automatizada & - & 25,00 & 25,00 \\
\hline $\begin{array}{l}\text { Kit Superscript III Platinum one- } \\
\text { step QRT-PCR 500reações }\end{array}$ & $6.655,70$ & 13,31 & 13,31 \\
\hline Sondas Taqman 6000 picomoles & 634,96 & 0,63 & 1,89 \\
\hline "Primer" $(100 \mu \mathrm{M})$ & 80,00 & 0,08 & 0,08 \\
\hline Rnase out $5000 U$ & 328,00 & 1,64 & 1,64 \\
\hline Tampas óticas 300 tiras com 8 & 272,10 & 0,11 & 0,11 \\
\hline \multirow[t]{2}{*}{ Tubos óticos Pacote com 1000} & 256,78 & 0,25 & 0,25 \\
\hline & & $\begin{array}{l}\text { Custo total } \\
\text { por reação }\end{array}$ & 42,28 \\
\hline
\end{tabular}




\subsection{Artigo submetido}

A etapa de desenvolvimento e os resultados correspondentes da genotipagem do VHC por PCR em tempo real foram descritos no artigo "Hepatitis C Virus Genotyping by Real-Time PCR Based on the NS5B Region." (Anexo B) 


\section{DISCUSSÃO}

O genoma do vírus da hepatite $\mathrm{C}$ apresenta uma alta variabilidade genética que se traduz pela classificação em seis diferentes genótipos definidos pelas análises filogenéticas. Estes podem diferir em mais de 30\% nas seqüências de nucleotídeos (35). Além disso, o VHC possui mais de 80 subtipos que podem diferir de 20 a $25 \%$ entre si. Isto se deve em parte à falta do mecanismo de revisão pela RNA polimerase. Também se reflete na presença heterogênea de "quasispecies" dentro uma mesma infecção cuja sequência genética pode variar em torno de 10\% entre os mesmos (137). Esta alta variabilidade contribui para a patogênese, persistência da infecção e a dinâmica da transmissão(36)

A genotipagem do VHC continua sendo a principal ferramenta como prognóstico da evolução da doença e tempo do tratamento. Além disso, importante para a compreensão da evolução e epidemiologia do vírus, uma vez que os genótipos variam de acordo com a região geográfica e muitas vezes estão correlacionados com fatores de risco como uso de drogas injetáveis (35).

Existem diferentes métodos moleculares para a caracterização dos genótipos e entre eles o seqüenciamento é o padrão ouro para este procedimento. A melhor forma de identificar o genótipo é o seqüenciamento do genoma completo, o qual é impraticável em laboratórios clínicos de rotina devido à alta complexidade de procedimento (79). Assim o método de referência padrão é o seqüenciamento de uma porção específica amplificada através de PCR, 
seguido de análise filogenética ou comparação com seqüências depositadas em banco de dados como o GenBank. As seqüências mais utilizadas para a análise são provenientes das regiões NS5B, E1 e 5'UTR (118). O seqüenciamento necessita de equipamento de alto custo e mão de obra qualificada porém a maior dificuldade dentro de um laboratório clínico é o tempo de execução pois o seqüenciamento envolve diferentes etapas de processamento desde a transcrição reversa no caso de um vírus RNA até as análises das seqüências. Após o processamento de PCR leva em torno de 16 horas (84).

Por outro lado, a tecnologia da PCR em tempo real que consiste de um equipamento com uma plataforma integrada, para detecção, quantificação e monitoramento em tempo real dos produtos amplificados, permite que a detecção seja realizada de forma automatizada na fase exponencial da reação, através da utilização de sondas marcadas com fluoróforos não-específicos (que se ligam ao DNA indiscriminadamente) ou fluoróforos específicos (ligados a oligonuceotídeos alvo-específicos), sendo ambos detectados por um sistema ótico e um detector CCD ("Charge Couple Device"). Um "software" monitora a amplificação por PCR a cada ciclo em tempo real, eliminando assim a necessidade de utilização de eletroforese ou de outros processamentos pós-PCR e permitindo assim que essa reação seja realizada num único tubo, o que minimiza os problemas de contaminação. Em consequência, a reação se torna mais rápida, sensível e reprodutível (138). Essa nova tecnologia permitiu o desenvolvimento de diagnósticos de uma forma mais sensível e com uma relação custo benefício maior. 
Desse modo, o objetivo deste trabalho foi o desenvolvimento de um método de genotipagem do VHC através da PCR em tempo real através da análise da região NS5B, uma região polimórfica que permite diferenciar os subtipos de modo mais preciso. Em nossa pesquisa, a escolha da região do VHC para a genotipagem foi determinada pela necessidade de um método que pudesse discriminar de forma mais acurada os genótipos e seus subtipos. O método de referência para determinação dos subtipos do VHC é a análise filogenética baseado no seqüenciamento das regiões NS5B core ou E1, regiões menos conservada que permite diferenciar de modo mais adequado os tipo e subtipos do VHC (118). Para isto foram seqüenciadas diferentes amostras com diferentes genótipos e a partir destas seqüências foram desenhadas dentro de uma região do NS5B "primers" "forward" e "reverse" para os genótipos 1 e 3 e diferentes sondas marcadas com fluoróforos específicos para cada subtipo (1a, 1b e 3a) em cada canal de leitura do sistema ótico. A escolha destas sondas e "primers" para os genótipos e subtipos 1a, 1b, 2a, $2 b, 2 c$ e $3 a$ foi determinada pela prevalência desses genótipos em mais de 99\% na população brasileira infectada (53).

Todos os conjuntos de "primers" e sondas foram desenhadas de acordo com regras preestabelecidas como $\mathrm{Tm}$ de $60^{\circ} \mathrm{C}$ para "primers" e $10^{\circ} \mathrm{C}$ acima $\left(70^{\circ} \mathrm{C}\right)$ para as sondas. Entretanto, o primeiro conjunto de sondas para os genótipos 1a, 1b e 3a não correspondeu de forma precisa na amplificação destes genótipos principalmente o genótipo 3a (dados não apresentados). Em razão disso, novo conjunto de "primers" e sondas foram desenhados dessa vez focando um número menor de nucleotídeos. Com essa estratégia 
foi possível minimizar o polimorfismo presente na região NS5B. Por serem oligonucleotídeos mais curtos, a temperatura de "melting" foi calculado em $66^{\circ} \mathrm{C}$ para as sondas e $56^{\circ} \mathrm{C}$ para os "primers". Para ocorrer a amplificação foi necessário acrescentar um passo de $50^{\circ} \mathrm{C}$ nas ciclagens da PCR em tempo real.

Para o genótipo 2 foram desenhados um par de "primers" e três sondas marcadas para detectar os subtipos $2 \mathrm{a}, 2 \mathrm{~b}$ e $2 \mathrm{c}$ dentro dos padrões preestabelecidos. Após os testes este conjunto de "primers" e sondas mostrou-se adequado para a tipagem do genótipo 2 e seus subtipos.

Nas etapas do desenvolvimento e padronização do método de genotipagem por PCR em tempo real, vários processos foram testados. Em razão do VHC ser um vírus RNA, um dos pontos críticos do processo foi a escolha entre os sistemas "two-step" e "one-step" para a realização da genotipagem por PCR em tempo real. Inicialmente foi testada a reação no sistema 'two-step". Os primeiros testes foram realizados para a titulação da matriz isto é, verificar a menor concentração de "primers" e sondas e que apresente a melhor eficiência. Ficou determinado que a concentração de "primers" e sondas numa concentração de 200nM apresentava uma boa eficiência. Apesar de conseguirmos definir a concentração de "primers" e sondas com o sistema "two-step," os outros experimentos utilizando cDNA de amostras em que foram realizados a reação de transcrição reversa com MMLV-RT (Moloney murine leukemia vírus-RT) e "random primers" mostraram-se inconsistentes (dados não apresentados). Diferentes fatores podem ter contribuído para isso. Entre estes, vários estudos apontam que a temperatura de anelamento 
na transcrição reversa influencia na formação de estruturas secundárias na molécula de RNA, isto é, quanto maior a temperatura utilizada, menor a formação de estruturas secundárias, que pode influenciar na eficiência da reação (139). Outros estudos apontam que o tipo de "primer" utilizado na reação de transcrição reversa também pode influenciar a eficiência da reação (140). A utilização de "random primers" pode originar múltiplos segmentos diferentes de cDNA derivados do RNA original e com isto a transcrição pode perder a sensibilidade. A utilização de "primers" específicos resulta na síntese de cDNA mais específico e melhora portanto a sensibilidade dos testes em tempo real (141). Os fatores acima descritos podem ter contribuído para baixa eficiência da amplificação quando a reação foi realizado em sistema "twostep" para a genotipagem do VHC por PCR em tempo real, já que a reação de transcrição reversa foi realizada com a enzima MMLV e "random-primers".

Outro estudo mostra que não há diferença na eficiência da reação entre os sistemas "two-step" e "one-step" quando a taxa de expressão do gene alvo é alta. Entretanto, quando a taxa de expressão é baixa, a detecção ocorreu antes no sistema "one-step" com uma diferença de cinco ciclos a menos neste sistema. Assumindo uma eficiência de $100 \%$ isto significa que houve uma sensibilidade 32 vezes maior na detecção do gene para o sistema "one-step" (142).

A partir disso, o nosso trabalho foi direcionado para a padronização em sistema "one-step", com a utilização de "primers" específicos para a síntese de cDNA. O segundo passo foi a escolha de uma enzima que pudesse trabalhar em temperaturas maiores no processo de transcrição reversa. Diferentes 
estudos mostraram que a enzima utilizada tem um papel primordial na eficiência da reação (142) (143). No nosso estudo utilizamos um kit "one step" em que a enzima responsável pela transcrição é a Superscript III, uma versão modificada da MMLV-RT que possui uma estabilidade térmica de $45^{\circ} \mathrm{C}$ a $60^{\circ} \mathrm{C}$ o que diminui a formação de estruturas secundárias e reduz a atividade de RNase $\mathrm{H}(144)$.

Outro fator estudado foi a forma de incubação da reação de transcrição reversa. Primeiro a reação foi testada em uma única etapa em que foram acrescentados todos os reativos, inclusive o RNA extraído, com incubação no equipamento de tempo real ("one-step"). Em seguida o método foi testado com todos os reativos, mas o passo da transcrição reversa foi realizado no termociclador 9700 com a tampa aberta para verificar a influência da temperatura da tampa que chega a $105^{\circ} \mathrm{C}$ na atividade da enzima taq DNA polimerase ("one-step" com modificação na incubação). Por último foi realizada uma modificação na reação como descrito na seção "métodos" quando os reativos foram divididos em duas partes: uma parte dos reativos foi colocada no tubo ótico e outra parte dos reativos dentre estes o "primer forward" na tampa ótica ("one-step" modificado).

No sistema "one-step" modificado houve uma amplificação precoce em (média de 4,6 Cts) comparado com método "one-step", e de 6,16 Cts quando comparado com o método "one-step" com modificação na incubação. Uma das explicações é a adição do "primer forward" no tubo após a reação de transcrição reversa e antes da ativação da taq DNA polimerase. Estudos mostram que adição do "primer forward" após a reação de transcrição reversa 
previne a formação de 'primers-dimers" e resulta em uma amplificação mais eficiente (143). No nosso trabalho a adição do "primer forward" na tampa ótica permitiu que a reação fosse realizada sem a necessidade de abrir a tampa evitando uma possível contaminação entre as amostras, possibilitando que a reação realmente fosse realizada em uma única etapa.

Um ponto focado foi que o custo benefício de uma reação em que pudessem ser colocadas as três sondas no mesmo tubo ("reação triplex") seria vantajoso. Com este objetivo, os produtos de PCR relativos aos genótipos 1a, 1b e 3a foram gerados com um único par de "primers", enquanto as sondas foram marcadas com diferentes fluoróforos FAM, Vic e NED que utilizam canais de leituras diferentes no sistema ótico. A reação para detecção do genótipo 2 foi concebida utilizando a mesma estratégia, em que todos os produtos foram gerados a partir de um único par de "primers" e em que a sonda específica para cada subtipo (2a, $2 b$ e $2 c)$ foi marcada com um dos diferentes fluoróforos do conjunto anterior. Para verificar a eficiência de cada sonda dos diferentes genótipos foram realizados os testes em "monoplex" e "triplex". Foi constatado que as sondas para o genótipo 1b e 3a apresentaram uma eficiência maior. Esta eficiência foi de $30 \%$ e $40 \%$ maior para o genótipo $1 \mathrm{~b}$ e $3 \mathrm{a}$, respectivamente quando realizado a reação em "triplex". Em um teste anterior já havia sido verificado que a reação em "duplex" (quando as sondas para os genótipos 1a e 1b foram colocados no mesmo tubo) resultou em Cts inferiores em comparação com a reação em "monoplex". Não foram encontrados na literatura os fatores que poderiam 
influenciar a melhora da eficiência numa reação em "triplex" do que quando realizado com uma única sonda.

Outro fator determinante que influencia a eficiência da reação em tempo real é a quantidade de RNA utilizada na reação (139). Para um volume final de $50 \mu \mathrm{l}$, no presente trabalho foi padronizado um volume de $19 \mu$ l de RNA extraído, um volume maior que em outras referências, mas que se mostrou eficiente quando comparado com volumes menores de RNA. As médias das concentrações verificados neste estudo não apresentou diferenças entre os genótipos. Num estudo apresentado com genotipagem por PCR em tempo real o RNA é extraído a partir de $1.000 \mu \mathrm{l}$ de plasma e eluído em $80 \mu$ isto é, $12,5 \mathrm{X}$ mais concentrado (124). No nosso caso, partimos de $200 \mu \mathrm{l}$ de plasma e eluímos em $60 \mu \mathrm{l}$ isto é, 3,3 X mais concentrado. Compensamos com a adição de um volume maior de RNA na reação, pelo fato que muitas vezes não há volume suficiente de plasma para partirmos de $1000 \mu$ para a extração do RNA. A qualidade dos ácidos nucléicos também é crucial para a obtenção de resultados satisfatórios a partir de métodos moleculares. Assim, a utilização de técnicas de extração de ácidos nucléicos baseadas no método de Boom (130), com a utilização de sílica magnetizada, significou um avanço em comparação com métodos baseados em colunas de eluição ou métodos "in house". Como padrão-ouro para extração de DNA, essa tecnologia confere alta eficiência à extração de ácidos nucléicos com esgotamento das amostras (145). Além disso, os ácidos nucléicos extraídos apresentam rendimento e pureza superiores aos obtidos com as técnicas convencionais (146) (145). A utilização de um sistema automatizado como o 
deste trabalho pode reduzir os riscos de contaminação cruzada entre as amostras, além de permitir o processamento simultâneo de um número maior de amostras (147) (148). O processo de automação também promove a uniformização das etapas no processo de extração do DNA, minimizando variações de rendimento ou pureza decorrentes do processo manual.

Baseado em diferentes estudos que mostram o poder de discriminação da região NS5B (80) (85) o nosso trabalhou desenvolveu todas as sondas e "primers" para os genótipos mais prevalentes no Brasil baseados na região NS5B. Estudos relatam resultados falsos negativos em ensaios baseados na região NS5B de 18.3\% (85), por outro lado Murphy (2007) conseguiu uma sensibilidade de $97.3 \%$ na genotipagem da região NS5B porém, para isto, foi necessário o emprego de diferentes pares de primers(116). Uma das causas dessas diferenças pode ser a conjunção da região empregada com o método empregado como o seqüenciamento. Em nosso trabalho de seqüenciamento com o objetivo de desenhar as sondas e "primers" para o VHC, houve $18 \%$ de resultados falsos negativos, isto é, apesar de haver amplificação muitas vezes não conseguimos definir os genótipos e seus subtipos pela qualidade das seqüências geradas.

Em contrapartida com o método de genotipagem por PCR em tempo real baseado na região NS5B, foram identificadas 97,93\% (190/194) das amostras do genótipo 1. O limite mínimo de detecção para o genótipo 1 b foi de $250 \mathrm{Ul} / \mathrm{ml}$ e para o genótipo 1a de $500 \mathrm{UI} / \mathrm{ml}$ A sensibilidade analítica deste método provou ser maior quando comparada com outro estudo que avaliou um método comercial de genotipagem por PCR em tempo real no 
sistema Taqman em que somente os genótipos 1a e 1b estão baseados na região NS5B. O limite mínimo de detecção neste teste foi de $1.500 \mathrm{UI} / \mathrm{ml}$ para os genótipos 1a e 1b (124). Umas das possíveis causas para essa diferença de sensibilidade pode estar relacionada com os desenhos das sondas: com um número menor de nucleotídeos foram minimizados os possíveis "mismatches" por mutações nos sítios de ligação das sondas. Nas quatro amostras em que não houve identificação dos genótipos por PCR em tempo real foram realizados as determinações das cargas virais. Em todas estas amostras foram realizadas reações de PCR com o objetivo de seqüênciar e verificar possíveis mutações. Em três amostras não houve amplificação na reação de $\mathrm{PCR}$, provavelmente em virtude de uma baixa afinidade com os "primers," que é um dos problemas mais comuns quando a região escolhida é polimórfica como a região NS5B (116). Somente em uma amostra foi possível identificar duas trocas de nucleotídeos na região das sondas para o genótipo 1a, demonstrando que a principal limitação para a realização da genotipagem, em uma região mais polimórfica é o fato de eventuais mutações levarem à baixa afinidade entre os "primers" e sondas desenhadas com a região alvo.

Quando comparamos a genotipagem do VHC por PCR em tempo real da região NS5B com o seqüenciamento parcial da região NS5B, houve uma total concordância em relação ao tipo e subtipo demonstrando que o método desenvolvido apresentou uma acurácia de 100\%. Em relação a análise filogenética realizada com 138 seqüências deste trabalho não foi encontrado discrepâncias em relação aos resultados de genotipagem por 
PCR em tempo-real. Por outro lado, métodos comerciais como o Trugene e LiPA que utilizam a região 5'UTR obtiveram uma acurácia de 89,9 e 84,5\% respectivamente quando comparadas com a região NS5B em relação ao tipo (149).

Quando foram comparados os métodos de PCR em tempo real desenvolvido e o método de LiPA houve uma total concordância em relação ao tipo, quando foi considerado a identificação de um único genótipo.

Estes resultados estão de acordo com outro estudo quando houve uma concordância de 99,5\% quando comparado o método de genotipagem baseado na região 5'UTR com seqüenciamento baseado na região NS5B (149). Apesar da alta conservação da região 5'UTR, diferentes estudos mostram que a diferenciação para o tipo do genótipo é acurado para a maioria dos genótipos (80).

Entretanto alguns métodos de genotipagem que empregam a região 5'UTR identificam de modo incorreto algumas variantes do genótipo 6 , descritos do sudoeste de Ásia como genótipo 1. Isto se deve pela inserção de dois nucleotídeos CA, após a posição 196 da região 5'UTR que acreditava-se ser altamente conservada mas posteriormente encontraram outras inserções como CG e CT entre os subtipos do genótipo 6a que são similares ao genótipo 1(77). Outro artigo relata a discordância de identificação em relação ao genótipo 2 caracterizada pelo LiPA e através do seqüenciamento da região NS5B determinada como genótipo 1 (149). Porém, a alta conservação da região 5'UTR faz dela a região de escolha para a maioria dos testes de genotipagem comerciais e não comerciais. Esta região 
consiste em 341 nucleotídeos, sendo a seqüências destes nucleotídeos altamente conservadas entre as cepas virais (similaridade maior que 92\%). Por esta razão, raramente ocorre falha na amplificação por mutação no sitio de ligação dos "primers" quando comparados como outras regiões mais heterogêneas do VHC (150).

Paralelamente 25,48\% (79/310) amostras apresentaram resultados incompletos, indefinidos ou discordantes em relação aos subtipos determinados pelo LiPA em comparação com o método de genotipagem por PCR em tempo real quando excluímos as amostras em que o método desenvolvido não conseguiu detectar. Isto se verificou principalmente em relação ao genótipo 1 quando LiPA apresentou resultados incompletos, indefinidos ou discordantes em 30,92\% (60/194) das amostras. Na verdade nenhum dos métodos baseados na região 5'UTR pode ser utilizado com segurança para definição do subtipo. Isso é particularmente verdadeiro em relação ao novo algoritmo de interpretação do LiPA Versant que falha na subtipagem, visto que, a maioria das combinações de hibridização resulta somente no genótipo 1 (149). Estudos demonstram que a falha na região 5'UTR para a subtipagem principalmente entre os subtipos 1a e 1b, se deve ao fato que o fragmento analisado difere somente em 1 nucleotídeo na posição 99 (79). Outro dado é que o nucleotídeo G na posição 243 da região 5'UTR era considerado representativo do genótipo 1b, porém foi encontrado em populações do genótipo 1a (80) (81). Outro autor relata que a freqüência do genótipo 1b é superestimada em relação ao genótipo1a. Neste artigo, LiPA identificou a prevalência do subtipo $1 \mathrm{~b}$ com uma taxa de $13 \%$ maior que o 
real (79). No presente trabalho 10,76\% (7/65) das amostras do genótipo 1a foram identificadas como genótipo $1 \mathrm{~b}$ pelo LiPA. Além disso, o LiPA não conseguiu discriminar o subtipo em oito amostras que foram identificadas como 1a/1b. Dessas, seis amostras foram subtipadas como 1a e duas amostras como genótipo $1 \mathrm{~b}$ pelo método desenvolvido. $\mathrm{O}$ perfil de hibridização no LiPA para 1a/1b é a amplificação nas bandas 1, 2, 3, 4 e 8, como a banda 1 é o controle de adição do conjugado e a banda 2 o controle de adição do amplificado, a hibridização somente nas três bandas restantes não permite definir o subtipo como 1a ou 1b. Por outro lado nesta pesquisa duas amostras do genótipo $1 \mathrm{~b}$ foram detectadas com a sonda alternativa 1 b66 demonstrado que podem ocorrer variantes na região das sondas, apesar de menor probabilidade.

Em relação ao genótipo 2, 86,11\% (31/36) das amostras foram identificadas pelo método de genotipagem por PCR em tempo real. Um dos problemas encontrados nessa pesquisa foi o pequeno número de amostras testadas. Para os genótipos 1 e 3 todas amostras utilizadas para a genotipagem por PCR em tempo real eram diferentes das amostras que foram seqüenciadas para o desenho das sondas e "primers." Esse cuidado se deu para evitar um viés em relação a identificação dos genótipos. Por outro lado, em relação ao genótipo 2, dezenove amostras já haviam sido utilizadas anteriormente no seqüenciamento. Foi necessário utilizar essas amostras novamente por causa da baixa prevalência desse genótipo em nosso meio ou porque necessitávamos de subtipos encontrados em menor prevalência em nossa casuística, como 2a e 2c. Das cinco amostras que não foram determinadas 
as genotipagens por PCR em tempo real, quatro amostras pertenciam a esse lote de amostras. Umas das explicações é que as amostras foram manipuladas em diferentes ocasiões com etapas de congelamento e descongelamento o que pode ter acarretado a degradação do RNA viral. Entretanto, em três amostras do genótipo 2 que não amplificaram tiveram carga viral detectável, sendo que uma delas não pertencia ao lote das amostras reutilizadas. Nas outras duas amostras não houve amostra suficiente para re-análise. Para verificar uma possível mutação no sítio de ligação dos "primers" e sondas realizamos uma PCR com "primers" da região NS5B para posterior seqüenciamento parcial dessa região. Porém não houve amplificação por PCR para as duas amostras testadas. Uma das causas pode estar relacionada ao polimorfismo encontrado na região NS5B, ou seja, os "primers" ou sondas tiveram baixa afinidade ao sítio de ligação. Há evidências de que o principal determinante de resultados falso negativo seja a alta diversidade genética do VHC entre tipos e subtipos (147).

Em relação aos subtipos do genótipo 2, 52,77\% (19/36) não foram subtipadas ou não houve uma identificação correta dos subtipos pelo LiPA, quando comparados com a genotipagem por PCR em tempo real. Quatorze amostras foram identificadas somente como genótipo 2 pelo LiPA e no entanto foram identificados como $2 \mathrm{~b}$ pela genotipagem por PCR em tempo real. No nosso estudo três amostras foram identificados como $2 \mathrm{a} / 2 \mathrm{c}$ pelo LiPA e foram identificadas como 2c pela genotipagem por PCR em tempo real baseado na região NS5B. Vários estudos demonstram que a identificação dos genótipos $2 a$ e $2 c$ não podem ser distinguidos baseados na região 
5'UTR (92) (80). Por outro lado, mais amostras do genótipo 2 deverão ser testados para verificar a sua real eficiência e sensibilidade frente as sondas e "primers" desenhadas no presente trabalho.

Em relação ao genótipo 3a, 100\% (80/80) das amostras foram detectadas com o método de genotipagem por PCR em tempo real, provando que a sonda para esse genótipo é eficiente. Não houve também discrepâncias em relação ao subtipo quando comparados os métodos de LiPA e seqüenciamento da região NS5B com o método de genotipagem por PCR em tempo real.

De maneira geral, o teste de genotipagem desenvolvido conseguiu detectar 97,09\% (301/310) das amostras com eficiência similar à descrita em outros trabalhos $(116,124)$.

Infecções mistas têm sido relatadas em diversos estudos, estas têm sido detectadas em maior número em pacientes hemofílicos, usuários de drogas injetáveis e pacientes sob tratamento de hemodiálise (151) (152) (153). A detecção de infecção mista varia do método empregado e muitas vezes são detectadas em um método, mas não são confirmadas no segundo método (154) (152). Num estudo multicêntrico, somente dois laboratórios foram capazes de detectar corretamente a mistura de genótipos com base no seqüenciamento da região NS5B (85).

Pelo método desenvolvido em nosso trabalho, 1,93\% (6/310) das amostras foram detectadas concomitantemente por duas sondas. Destas, uma amostra foi detectada com sondas 1a e $3 a$ e cinco amostras foram detectadas pelas sondas 1a e 1b. Duas dessas amostras haviam sido caracterizadas pelo LiPA como genótipo 1 e quatro amostras como genótipo 
1b. Notadamente, todos os Cts dos genótipos caracterizados pelo LiPA foram menores, possivelmente mostrando que a população mais prevalente foi detectado pelo LiPA. Em duas amostras foram realizadas diluições de parâmetro final, e foram possíveis amplificar os dois genótipos até a diluição de $500 \mathrm{Ul} / \mathrm{ml}$. Na diluição de $250 \mathrm{Ul} / \mathrm{ml}$, verificou-se que houve uma correlação direta entre o CTs e o número de réplicas amplificadas, isto é, o genótipo prevalente com CTs menores apresentaram maior número de amplificações. Entretanto, não é possível confirmar a infecção mista somente com este teste. Para tanto seria necessário caracterizar essas infecções através de ensaios de clonagens e piroseqüenciamento (155). Para verificar se esses pacientes pertenciam a um grupo de risco os seus dados clínicos foram rastreados. Dois pacientes dos seis pacientes não apresentaram relação com nenhum desses grupos. Porém, um paciente cuja amostra foi detectada pelas sondas 1a e 3a foi relatado como usuário de droga. A amostra de outros dois pacientes também apresentaram correlação clínica sugestivos de infecção mista pelos genótipos 1a e 1b, um paciente é submetido a seções de hemodiálise e outro é um paciente hemofílico. Em um único paciente não conseguimos rastrear os dados clínicos. Em outro trabalho de genotipagem por PCR em tempo real ocorreu uma amplificação concomitante com 2 sets de "primer" e sondas em 32,6\% das amostras. Para minimizar esse número alto de supostas infecções mistas, foram consideradas no teste de validação somente amostras com diferença máxima de 3 ciclos entre os Cts obtidos com diferentes sondas, indicando a presença de múltiplos genótipos. Desse modo, somente 23 amostras ou 
$1,4 \%$ foram considerados como infeção mista (124). No presente trabalho não houve reações cruzadas como descrito nesse artigo, somente as seis amostras apresentaram amplificações concomitantes com duas sondas. A ausência de reações cruzadas ocorreu possivelmente porque as sondas utilizadas nesse trabalho foram desenhadas todos na região NS5B. Dentro dessa região, todas as sondas dos dois conjuntos reacionais $1 \mathrm{a}, 1 \mathrm{~b}, 3 \mathrm{a}$ e $2 \mathrm{a}$, 2b, 2c utilizaram como alvo exatamente as mesmas posições nucleotídicas, diferentemente do método comercial de genotipagem por tempo real, em que somente as sondas 1a e 1b são baseados na região NS5B e os outros genótipos baseados na região 5'UTR (124).

Para determinar se realmente o método desenvolvido seria capaz de detectar mistura de genótipos, misturamos artificialmente o RNA de dois genótipos (1a e 3a). Após as diluições, foi possível detectar os dois genótipos em todas as diluições e proporções, demonstrando que o nosso método tem a capacidade de determinar a mistura de genótipos simulada in vitro. Estudos mais aprofundados serão necessários para a confirmação destes resultados.

Em outros parâmetros de validações como reprodutibilidade e especificidade o método desenvolvido se mostrou adequado.

Não houve reações cruzadas com outros vírus da hepatite A e B, além do HIV que está relatado em muitos pacientes como coinfecção com VHC e o vírus da dengue que pertence a mesma família Flaviviridae.

Existem poucos trabalhos utilizando PCR em tempo real para a genotipagem do VHC. Todos os trabalhos utilizam a região 5'UTR como alvo, exceção do método comercial em que os genótipos 1a e 1b são focados na 
região NS5B e os genótipos 2, 3, 4, 5 e 6 são baseados na região 5'UTR (124) (156). Pela plataforma TaqMan, Moghaddam (2006) (106) descreve a determinação dos genótipos 1, 2 e 3a em 37 pacientes da Noruega. Houve uma correlação de $100 \%$ com seqüenciamento da região 5'UTR e LiPA.

O método de PCR em tempo real desenvolvido no presente estudo apresentou um custo final menor que os métodos comerciais utilizados em nosso meio. Somados todos os insumos o custo não ultrapassou o valor de $\mathrm{R} \$ 42,28$ por reação. Pelo nosso esquema de diagnóstico primeiramente faríamos a reação em "triplex" para os genótipos 1a, 1b e 3a, estes genótipos são os mais prevalentes na população brasileira. Se negativo partiríamos para o segundo set de reação para os genótipos $2 a, 2 b$ e $2 c$. Nesse caso o custo da reação sairia por $\mathrm{R} \$ 59,56$ descontado o valor da extração dos ácidos nucléicos. Se negativo partiríamos para a pesquisa qualitativa do RNA do VHC e se positivo a genotipagem será realizado por um método de genotipagem focado na região 5'UTR. Porém, se calcularmos o valor do teste no algoritmo descrito e considerarmos que a sensibilidade do nosso teste é de $97 \%$ e inferirmos a prevalência dos genótipos do VHC na população infectada do Brasil, o valor do teste seria de $\mathrm{R} \$ 58,34$ para cada cem testes realizados. Um valor nove vezes menor que o esquema utilizado atualmente com o método comercial no nosso laboratório.

Outro ponto a favor do método desenvolvido é o tempo de mão-deobra despendido. Para o método LiPA, o tempo necessário para a execução dos procedimentos de extração dos ácidos nucléicos, amplificação, detecção, hibridização, lavagens, interpretação e liberação dos resultados é de cerca 
de 16 horas. No método desenvolvido, esse tempo cai para menos de 2 horas trabalhadas, sem a necessidade de manipulação constante como no método LiPA. Por ser um método semi automatizado os resultados de genotipagens seriam liberados no mesmo dia, o que traria benefícios para o fluxo laboratório-paciente. Outro ponto favorável é que o método desenvolvido com o sistema "one-step" modificado permitiu que todos os passos das reações pudessem ser realizados em uma única etapa, minimizando problemas de contaminações cruzadas entre amostras, que é um cuidado essencial na utilização de métodos moleculares. A reação em "triplex" foi outro ganho na metodologia pelo menor tempo de execução e menor custo quando condensamos a pesquisa de três genótipos numa única reação. O método utilizou a região NS5B como alvo, importante para estudos epidemiológicos, correlação clínica de resposta ao tratamento dos diferentes tipos e subtipos frente a novas drogas que estão sendo desenvolvidas. O método desenvolvido vai possibilitar a correlação clínica de um modo mais acurado frente aos diferentes genótipos e seus subtipos e entender melhor o papel da variabilidade genômica na história natural da infecção do VHC. O método de genotipagem por PCR em tempo real privilegiou uma alta acurácia em relação aos subtipos, mas em aproximadamente 3\% dessa população estudada não houve amplificação provavelmente devido à baixa afinidade dos "primers" e sondas nos sítios de ligação em consequência do alto polimorfismo que a região apresenta.

Finalmente o trabalho é inédito, pois não há estudos publicados com relação a genotipagem por PCR em tempo real focado na região NS5B do VHC para os genótipos e subtipos, em um sistema "one-step" modificado 
com reação em "triplex". O método desenvolvido teve um valor agregado ao possibilitar uma redução nos custos nove vezes menor que o kit comercial, além da redução no tempo de execução do teste. 


\section{CONCLUSÕES}

O método de genotipagem por PCR em tempo real focado na região NS5B, desenvolvido no presente trabalho possibilitou:

Realizar as reações em um sistema "one-step" modificado com reação em "triplex" para as identificações dos genótipos (1a, 1b, 3a) e (2a, 2b, 2c)

Uma acurácia de 100\% quando comparamos cem amostras entre o seqüenciamento parcial da região NS5B e o método de genotipagem por PCR em tempo real.

Determinar a genotipagem em 97\% (301/310) das amostras quando comparadas com o método LiPA.

Definir todos os subtipos que apresentaram resultados incompletos, indefinidos ou discordantes pelo método LiPA.

O método desenvolvido teve um valor agregado em custo e no tempo de execução. 


\title{
7 ANEXOS
}

\author{
ANEXO A \\ COMPARATIVE EVALUATION OF HEPATITIS C GENOTYPING 5' \\ UNTRANSLATED REGION VERSUS NS5B REGION FROM \\ BRAZILIAN PATIENTS WITH CHRONIC HEPATITIS C
}

Running title: Comparison of HCV genotyping methods.

Comparative Evaluation of Hepatitis C Genotyping 5' Untranslated

Region versus NS5B Region from Brazilian Patients with Chronic

Hepatitis C.

Sueli M Nakatani ${ }^{\mathrm{a}, \mathrm{b}}$, Suzane K Ono-Nita ${ }^{\mathrm{b}^{*}}$, Irina N Riediger ${ }^{\mathrm{a}}$, Carlos A

Santos $^{\mathrm{c}}$, Marcelo Nita ${ }^{\mathrm{b}}$, Marco Aurélio Krieger ${ }^{\mathrm{d}}$, Flair J. Carrilho,

a Laboratório Central do Estado do Paraná - LACEN-PR, Curitiba, Paraná, Brazil

${ }^{\mathrm{b}}$ Department of Gastroenterology, São Paulo University School of Medicine -

São Paulo, Brazil.

${ }^{\mathrm{c} C e n t r o ~ d e ~ G e n o m a s, ~ S a ̃ o ~ P a u l o, ~ B r a z i l . ~}$

d Instituto de Biologia Molecular do Paraná (IBMP), Curitiba, Paraná, Brazil

${ }^{*}$ Correspondent author.

Phone +55 11 3069-7830e-mail: skon@usp. br 


\section{Abstract}

Genotyping of hepatitis C virus (HCV) has become an essential tool for prognosis and duration of treatment prediction. The aim of this study is to compare two HCV genotyping methods of $\mathrm{HCV}$ by reverse hybridization line probe assay, and nucleotide sequencing of NS5B amplicons. Plasma samples of 164 patients with chronic hepatitis C were screened using both commercial method (LiPA) and NS5B sequencing method. For thus, all the primers were designed in this study based in NS5B region. Comparison of HCV genotypes methods showed no difference in the classification at the genotype level. However, 58 samples (35.36\%) could not be discriminated at the subtype level when the mixed infections were excluded. All the samples were further subtype by NS5B sequencing. Three samples showed LiPA patterns suggestive of mixed-genotypes infection as like 1 and 3 . None of the samples showed mixed infection with NS5B sequences. HCV sequences analysis of NS5B provides precise genotype and subtype identification and an accurate epidemiological picture of circulating viral strains.

Keywords: HCV, genotypes, NS5B, 5'UTR. 


\section{Introduction}

The Hepatitis $\mathrm{C}$ virus (HCV) viral genome is highly variable, and since its first description (Choo et al. 1989), six major types and around 80 subtypes were already recognized. The nucleotide level differs by $31 \%$ to $33 \%$ among genotypes, and by $20 \%$ to $25 \%$ between subtypes (Simmonds et al. 2005). Genetic variation is not uniformly distributed throughout the genome, with the region encoding envelope glycoproteins being the most variable, compared to the highly conserved 5' untranslated region (5'UTR) of the HCV genome (Smith et al. 1995). Most of the commercially available genotyping methods are based on the 5'UTR. However, the ability of the sequence of this region to discriminate isolates at the subtype level is controversial, and alternative genomic regions have been proposed for use in genotyping (Corbet et al. 2003). The widely accepted reference standard for HCV genotyping is nucleotide sequencing of NS5B amplicons (Sandres-Saune et al. 2003). The aim of the present study was to compare genotyping based on NS5B region sequencing to a commercial method performed on a 5' UTR region (LiPA) in plasma samples obtained from Brazilian patients.

\section{Material and methods}

\subsection{Plasma samples}

One hundred and sixty four plasma samples representing genotypes 1, 2, 3, 4, and 5 were used in this study. All samples had previously been genotyped by line probe assay (LiPA) using the Versant ${ }^{\mathrm{TM}}$ HCV Genotype Assay (Bayer, Tarrytown, NY, USA) after amplification of 244 nucleotides 
long fragment of the 5'UTR generated by Amplicor® Hepatitis C Virus (HCV) Test, version 2.0 (Roche, Branchburg, NJ, USA), according to manufacturer's instructions.

This study was approved by the IRB from the Hospital das Clínicas at the University of São Paulo School of Medicine.

\subsection{RNA extraction}

RNA extration was performed by using Nuclisens Magnetic Extraction Reagents (bioMérieux, Boxtel, The Netherlands). A total volume of $200 \mu \mathrm{l}$ of plasma was added to lysis buffer and incubated for ten minutes at room temperature. Then the magnetic silica particles were used for nucleic acid binding for ten minutes at room temperature. Silica particles were washed with different buffers. The Nuclisens miniMag apparatus was used to collect and wash the particles. The nucleic acid was recovered from the silica particles during a five minutes incubation period at $60 \square \mathrm{C}$, using $50 \mu \mathrm{l}$ of elution buffer.

\subsection{RT-PCR}

For cDNA synthesis was performed essentially as previously described (Kusser et al., 2006). For RT, $40 \mu$ of RNA was added to a reaction mixture (3.3 $\mu$ l of random primer $150 \mathrm{ng} / \mu \mathrm{l} ; 36.3 \mu \mathrm{l}$ DEPC- $\mathrm{H}_{2} \mathrm{O}$ ) and incubated at $70^{\circ} \mathrm{C}$ for $10 \mathrm{~min}$. Then, $24 \mu \mathrm{l}$ of RT mixed (5X buffer, DTT(0.1M), dNTPS (10mM),

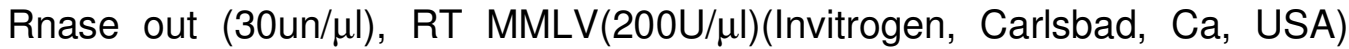
were added. Reactions were performed in GeneAMP PCR Systems 9700 
(Apllied Biosystems, Foster, Ca, USA) using the following amplification conditions: $25^{\circ} \mathrm{C}$ for $15 \mathrm{~min}, 3^{\circ} \mathrm{C}$ for $1: 02 \mathrm{~min}, 95^{\circ} \mathrm{C}$ for $15 \mathrm{~min}$ a final hold at $4^{\circ} \mathrm{C}$.

\subsection{Amplification of the HCV cDNA}

All primer pairs described in this study were designed on the basis of NS5B region consensus sequences, obtained upon alignement of data provided by Los Alamos National Laboratory

(http://hcv.lanl.gov/components/hcv-

db/GET ALIGNMENTS/get alignment.comp).

Table I includes details for the primers (Invitrogen, Carlsbad, Ca, USA) used in PCR amplification of NS5B region. Each PCR reaction contained buffer [10X, $200 \mathrm{mM}$ Tris- $\mathrm{HCl},(\mathrm{pH}$ 8.4), $500 \mathrm{mM} \mathrm{KCl}], \mathrm{MgCl}_{2}(50 \mathrm{mM})$, deoxynucleoside triphosphate $(10 \mathrm{mM}),(50 \mathrm{pmol})$ of each primer, Taq DNA polymerase high fidelity $2.5 \mathrm{UI}$ (Invitrogen) and $5 \mu \mathrm{l}$ of cDNA to be tested, in a final volume of $50 \mu \mathrm{l}$ completed with DEPC- $\mathrm{H}_{2} \mathrm{O}$. The PCR was carried out in a GeneAmp PCR System 9700 (Apllied Biosystems) using the following amplification conditions: $5 \mathrm{~min}$ at $94^{\circ} \mathrm{C}, 35$ cycles at $95^{\circ} \mathrm{C}$ for $30 \mathrm{~s},\left(60.5^{\circ} \mathrm{C}\right.$ for $1 \mathrm{~min}$ for primer NS5B2F/NS5B2R, 56 $\mathrm{C}$ for $45 \mathrm{~s}$ for primer F56_13/R56_1-3, 58ㅇ C for $45 \mathrm{~s}$ for primer GEN2FSN/GEN2RSN) and 72 $\mathrm{C}$ for 1 $\min ; 72^{\circ} \mathrm{C}$ for $10 \mathrm{~min}$; and a final hold at $10^{\circ} \mathrm{C}$.

\subsection{Nucleotide sequencing of NS5B region}

PCR products were purified using PureLink ${ }^{T M}$ PCR Purification Kit - 
(Invitrogen), then quantified (Kodak Digital Science -Analysis System 120 Rochester, NY USA) and diluted to $20 \mathrm{ng} / \mu \mathrm{l}$. Sequencing reaction was performed in both directions with Big Dye terminator version 3.2 and was performed using ABI 3130 Genetic Analyzer (Apllied Biosystems, Foster, Ca, USA).

\subsection{Sequence analysis.}

All nucleotide sequences from HCV strains were analyzed using Codon Code (Codon Code corporation, Dedham, MA, USA) and aligned with Bioedit (Hall, 1999) using a reference panel of reported sequences available in HCV sequence database (http://hcv.lanl.gov/content/hcv-

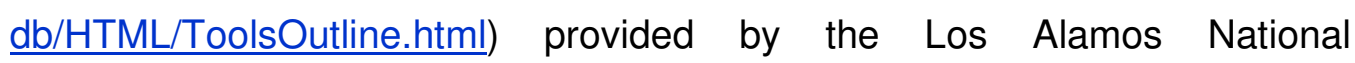
Laboratory.

2.7. Sequence accession number.

Twenty three partial HCV NS5B sequences of different genotypes in this study were submitted to GenBank and can be retrieved under accession numbers as follow: genotype 1a (EF136876 to EF136882); 1b (EF136870, EF136872, EF136873, EF1368874, EF136875, EF136883), 2b (EF136869);

2c (EF136868); 3a (EF136860 to EF136865); 4a (EF136867); 5a (EF136859).

2.8 Statistical analysis.

Agreement between pairs of techniques was assessed through the $\kappa$ coefficient (assuming a good concordance for $\kappa$ values between 0,61 and 
$0,80)$ when both methods classified specimens into the same categories. The statistical analyses were performed with program $R$ version 2.7 .9 for windows. For the concordance analysis were performed with program concord, version 1.4.9.

\section{Results}

3.1. HCV genome amplification.

Primer pair (Tablel) NS5B2F/NS5B2R has proved to be efficient in amplifying most of genotypes 1 to 5 . However, these primers have failed to amplify some samples. Among these samples, six samples were genotype 2 . In order to amplify these samples we designed another specific primer pair for genotype 2 (GEN2FSN/GEN2RSN). Among the amplified samples, five samples were classified as genotype $2 \mathrm{c}$ and one sample as $2 \mathrm{~b}$. Three samples were classified by LiPA as mixed infections involving genotypes 1 and 3. These samples were further analyzed using another primer pair which is more specific to genotypes 1 and 3 (F56_1-3/R56_1-3).

3.2. Comparison of HCV genotyping using 5'UTR (LiPA) and NS5B sequence analysis

Comparison of HCV genotypes based on NS5B sequence analysis showed no difference in the classification of the 164 types (Table II). The analysis of genotype concordance between techniques was assessed through the $\kappa$ coefficient showed a good concordance $0,6933(p<0,0001)$ when included only types results. However, when included subtypes we 
found only moderate agreement $0,4800(p=0,0118)$. Concerning subtypes, discrepant, incomplete or undefined results were found between LiPA and NS5B genotyping results at the subtype level for $35.36 \%(58 / 164)$ of samples, when mixed infection were excluded (Table III). LiPA could not discriminate twenty two samples of genotype 1 at subtype level, which were classified by NS5B sequences analysis as genotype 1a (21 samples) and as genotype 1b (2 samples). Three samples classified by LiPA as genotype $1 \mathrm{~b}$ were grouped as genotype 1a by NS5B sequences analysis. Among thirty samples of genotype 2, LiPA could identify only nine samples, typed as genotype 2b. However, thirty four samples of genotype 3 were correctly classified by LiPA as $3 a$ and confirmed by sequence analysis of NS5 B region.

\subsection{Mixtures and undefined genotypes}

LiPA classified eight samples as $1 \mathrm{a} / 1 \mathrm{~b}$, after sequences analysis of NS5B region; five samples were classified as genotype 1a, three samples as $1 \mathrm{~b}$. Two samples yielded banding patterns categorized as $2 \mathrm{a} / 2 \mathrm{c}$; after sequences analysis these samples were typed as 2 c. Three samples indicated a mixed banding pattern by LiPA, and were classified as genotype 1 and 3. Two of these samples, when submitted to sequence analysis of NS5B region, showed that two samples were classified as genotype $3 a$ and one sample as genotype 1a. None of other samples showed mixed infection with NS5B sequences (Table 3). 


\section{Discussion.}

Genotyping assays are usually based on sequence analysis of an amplified segment of the genome, commonly the 5'untranslated region, because it is targeted by most diagnostic assays for HCV RNA. Currently used 5'UTR based assays are acceptably accurate with more than 95\% concordance with genotypes identified by nucleotide sequencing in NS5B or other coding regions of the genome (Simmonds et al. 1993). In our study, LiPA and NS5B sequencing showed $100 \%$ agreement to type level, when mixed genotypes infections were excluded. These results were similar to those reported by other studies where 5'UTR was able to genotype $99.4 \%$ with type agreement to $99.5 \%$ when compared two methods based on 5'UTR (Nolte et al. 2003). Another study with 357 isolates from blood donors in France demonstrated full agreement between 5`UTR and NS5B sequence analysis regarding to type classification (Cantaloube et al. 2006). Depending on the geographical region, genotype identification based on 5' UTR can be a problem because some genotype 6 variants found in Southeast Asia have identical 5'UTR sequences to those of genotype 1a or 1b (Murphy et al. 2007). In Brazil, the most prevalent genotypes are 1, 2 and 3, genotypes 4 and 5 are rarely found and genotype 6 has never been identified (Holland et al. 1996, Levi et al. 2002, Campiotto et al. 2005, Silva et al. 2007).

When we compared the results of the two methods at the subtype level we found $35,3 \%(58 / 164)$ misclassification among samples. LiPA could not discriminate $47.6 \%(20 / 42)$ of genotypes 1a samples at subtype level. LiPA classified three samples of genotype $1 \mathrm{a}$ as genotype $1 \mathrm{~b}$. This may have 
possibly happened because the only sequence motif capable of discriminating between subtypes $1 \mathrm{a}$ and $1 \mathrm{~b}$ was covered by probe 5 or 6 . The difference between them is a single nucleotide change, an $A$ to $G$ transition at position -99. Actually, there are evidence that the $A / G$ at position - 99 represents a sequence polymorphism in the HCV genome that cannot differentiate sutbype 1a from subtype $1 \mathrm{~b}$ isolates (Andonov \& Chaudhary, 1995). Furthemore, eight samples could not be properly typed by LiPA and were classified as $1 \mathrm{a} / 1 \mathrm{~b}$. The banding pattern of these samples showed hybridization with probes $1,2,3,4,5$. Probe 1 is always the conjugate control and the probe 2 is the amplification control. Probes 3, 4, and 5 were not able to discriminate between genotypes $1 \mathrm{a}$ and $1 \mathrm{~b}$. By sequence analysis of NS5B region, three samples were classified as $1 \mathrm{~b}$ and five samples as genotype 1a.

In our study, only $30.0 \%$ (9/30) samples of genotype $2 b$ exhibited concordance between LiPA and NS5B sequence analysis results. Likewise, $61 \%$ of strains of genotype 2 were misclassified by 5 'UTR analysis in France (Cantaloube et al. 2006). In our study two samples cannot be distinguished by LiPA and released as 2a/2c. Nineteen samples of genotype 2 could not be subtype by LiPA and after sequence analysis of NS5B region eleven samples were classified as $2 \mathrm{~b}$, seven samples as $2 \mathrm{c}$ and one sample as $2 \mathrm{a}$. This is not unexpected since LiPA targets 5'UTR, which nucleotide polymorphism cannot lead to the correct identification of subtypes 2a and 2c (Davidson et al. 1995, Vatteroni et al. 1997).

The reported prevalence of HCV mixed genotype infections appear to be a 
rare event and seems to be influenced by the population studied and the genotyping method employed (Quarleri et al. 2003). In one study, the author has found $2.2 \%$ of mixed infections, when six hundred patients sera were screened for infection with multiple genotypes using sequencing and serological assay in parallel (Schroter et al. 2003). Otherwise, only two laboratories correctly identified one of the three samples with mixtures of different genotypes based on NS5B sequencing in a national evaluation study (Laperche et al. 2005). Cases of mixed HCV genotypes have not been confirmed in our study, although LiPA banding pattern suggests mixed infection in three samples. For LiPA interpretation, probes 3, 4, 5, are considered positive for genotype 1 and the lines 13, 14, 15 for genotype 3, and these samples resulted uninterpretable patterns. The genotype assignments of these samples were confirmed by BLAST searches and all samples were characterized as only one genotype. These results are similar to another study in Brazil with 1.688 sequential samples from chronic HCV patients and there was no mixed infection identification (Campiotto et al. 2005). Thus, the only approach to reliably detect mixed-genotype infections is by PCR amplification, followed by cloning of the PCR products and subsequent analysis of sequences of the individual clones generated by pyrosequencing. Nevertheless, this is unfeasible in a routine clinical setting (Buckton et al. 2006).

5 UTR region -based genotyping method showed higher sensitivity than NS5B region to amplify PCR products because primers from 5 'UTR, a highly conserved region, produce less false negative results of HCV PCR. Perhaps 
the most important factor of false negative is the existence of different strains or subtypes of HCV (Wang et al. 1992). Around 18\% of the strains employed in our study were not amplified by NS5B primers and were thus not reported. Since this region is not entirely conserved, difficulty to generate amplicons may be due to inadequate primer design, choice of highly polymorphic annealing sequences or low viral load. These results were similar to those described before, when assays based on analysis of the NS5B region missed $16.4 \%$ of the expected positive results (Laperche et al. 2005).

In the future a protective vaccine and the activity of HCV antiviral based proteases or polymerase will probably require genotyping at subtype level and enhance the importance of understanding the genetic diversity of HCV. Our results show that genotyping of HCV by nucleotide sequence analysis of NS5B is efficient allowing an accurate discrimination of subtypes and is also an effective tool for studying the molecular epidemiology of HCV. However, genotyping methods based on 5'UTR is an important tool for routine clinical purposes and can be sufficiently precise at genotype level.

\section{Acknowledgements}

These investigations were supported in part by grants from Secretaria de Saúde do Estado do Paraná, Fundação Araucária and Alves de Queiroz Family Fund for Research. We are indebted to Jacqueline Mendes de Oliveira and Marcelo M. Tavares de Souza for careful reading of the manuscript. 


\section{References}

1. Buckton, A. J., S. L. Ngui, C. Arnold, K. Boast, J. Kovacs, P. E. Klapper, B. Patel, I. Ibrahim, S. Rangarajan, M. E. Ramsay, and C. G. Teo. 2006. Multitypic hepatitis $C$ virus infection identified by real-time nucleotide sequencing of minority genotypes. J Clin Microbiol 44:2779-84.

2. Campiotto, S., J. R. Pinho, F. J. Carrilho, L. C. Da Silva, F. J. Souto, V. Spinelli, L. M. Pereira, H. S. Coelho, A. O. Silva, J. C. Fonseca, H. Rosa, C. M. Lacet, and A. P. Bernardini. 2005. Geographic distribution of hepatitis $C$ virus genotypes in Brazil. Braz J Med Biol Res 38:41-9.

3. Cantaloube, J. F., S. Laperche, P. Gallian, F. Bouchardeau, X. de Lamballerie, and P. de Micco. 2006. Analysis of the 5' noncoding region versus the NS5b region in genotyping hepatitis $\mathrm{C}$ virus isolates from blood donors in France. J Clin Microbiol 44:2051-6.

4. Corbet, S., J. Bukh, A. Heinsen, and A. Fomsgaard. 2003. Hepatitis C virus subtyping by a core-envelope 1-based reverse transcriptase PCR assay with sequencing and its use in determining subtype distribution among Danish patients. J Clin Microbiol 41:1091-100.

5. Davidson, F., P. Simmonds, J. C. Ferguson, L. M. Jarvis, B. C. Dow, E. A. Follett, C. R. Seed, T. Krusius, C. Lin, G. A. Medgyesi, and et al. 1995. Survey of major genotypes and subtypes of hepatitis $C$ virus using RFLP of sequences amplified from the 5 ' non-coding region. $J$ Gen Virol 76 (Pt 5):1197-204.

6. Hall, T. 1999. Bioedit: a user friendly biological sequence aligment editor and analysis program for windows 95/98/NT. Nucleic Acids Symp Ser 41:95-98.

7. Holland, P. V., J. M. Barrera, M. G. Ercilla, C. F. Yoshida, Y. Wang, G. A. de Olim, B. Betlach, K. Kuramoto, and H. Okamoto. 1996. Genotyping hepatitis $C$ virus isolates from Spain, Brazil, China, and Macau by a simplified PCR method. J Clin Microbio/ 34:2372-8.

8. Laperche, S., F. Lunel, J. Izopet, S. Alain, P. Deny, G. Duverlie, C. Gaudy, J. M. Pawlotsky, J. C. Plantier, B. Pozzetto, V. Thibault, F. Tosetti, and J. J. Lefrere. 2005. Comparison of hepatitis C virus NS5b and 5 ' noncoding gene sequencing methods in a multicenter study. $J$ Clin Microbiol 43:733-9.

9. Levi, J. E., D. T. Takaoka, R. H. Garrini, R. M. Fachini, R. Focaccia, E. De Bortholi Santos, H. P. Mitre, J. S. De Mendonca, N. De Paula Cavalheiro, A. A. Barone, and S. Wendel. 2002. Three cases of infection with hepatitis $C$ virus genotype 5 among Brazilian hepatitis patients. J Clin Microbiol 40:2645-7.

10. Murphy, D. G., B. Willems, M. Deschenes, N. Hilzenrat, R. Mousseau, and S. Sabbah. 2007. Use of sequence analysis of the NS5B region for routine genotyping of hepatitis $C$ virus with reference to $C / E 1$ and 5' untranslated region sequences. J Clin Microbiol 45:1102-12.

11. Nolte, F. S., A. M. Green, K. R. Fiebelkorn, A. M. Caliendo, C. Sturchio, A. Grunwald, and M. Healy. 2003. Clinical evaluation of two 
methods for genotyping hepatitis $\mathrm{C}$ virus based on analysis of the $5^{\prime}$ noncoding region. J Clin Microbiol 41:1558-64.

12. Quarleri, J. F., M. V. Bussy, V. L. Mathet, V. Ruiz, R. Iacono, L. Lu, B. H. Robertson, and J. R. Oubina. 2003. In vitro detection of dissimilar amounts of hepatitis $\mathrm{C}$ virus (HCV) subtype-specific RNA genomes in mixes prepared from sera of persons infected with a single HCV genotype. J Clin Microbiol 41:2727-33.

13. Sandres, K., M. Dubois, C. Pasquier, J. Puel, and J. Izopet. 2001. Determination of HCV genotype using two antibody assays and genome typing. Eur J Clin Microbiol Infect Dis 20:666-9.

14. Schroter, M., B. Zollner, P. Schafer, O. Landt, U. Lass, R. Laufs, and H. H. Feucht. 2002.

Genotyping of hepatitis $C$ virus types 1, 2, 3, and 4 by a one-step LightCycler method using three different pairs of hybridization probes. $J$ Clin Microbiol 40:2046-50.

15. Silva, C. M., C. Costi, L. P. Krug, A. B. Ramos, T. Grandi, V. L. Gandolfi, M. E. Menezes, M. Ocampos, C. Niel, and M. L. Rossetti. 2007. High proportion of hepatitis $C$ virus genotypes 1 and 3 in a large cohort of patients from Southern Brazil. Mem Inst Oswaldo Cruz 102:867-70.

16. Simmonds, P., J. Bukh, C. Combet, G. Deleage, N. Enomoto, S. Feinstone, P. Halfon, G. Inchauspe, C. Kuiken, G. Maertens, M. Mizokami, D. G. Murphy, H. Okamoto, J. M. Pawlotsky, F. Penin, E. Sablon, I. T. Shin, L. J. Stuyver, H. J. Thiel, S. Viazov, A. J. Weiner, and A. Widell. 2005. Consensus proposals for a unified system of nomenclature of hepatitis $C$ virus genotypes. Hepatology 42:962-73.

17. Simmonds, P., E. C. Holmes, T. A. Cha, S. W. Chan, F. McOmish, B. Irvine, E. Beall, P. L. Yap, J. Kolberg, and M. S. Urdea. 1993.

Classification of hepatitis $C$ virus into six major genotypes and a series of subtypes by phylogenetic analysis of the NS-5 region. $J$ Gen Virol 74 (Pt 11):2391-9.

18. Smith, D. B., J. Mellor, L. M. Jarvis, F. Davidson, J. Kolberg, M. Urdea, P. L. Yap, and P. Simmonds. 1995. Variation of the hepatitis C virus 5' non-coding region: implications for secondary structure, virus detection and typing. The International HCV Collaborative Study Group. J Gen Virol 76 (Pt 7):1749-61.

19. Vatteroni, M., F. Maggi, A. Morrica, C. Fornai, M. Giorgi, M. Pistello, and M. Bendinelli. 1997. Comparative evaluation of five rapid methods for identifying subtype $1 \mathrm{~b}$ and $2 \mathrm{c}$ hepatitis $\mathrm{C}$ virus isolates. $J$ Virol Methods 66:187-94.

20. Wang, J. T., T. H. Wang, J. C. Sheu, S. M. Lin, J. T. Lin, and D. S. Chen. 1992. Effects of anticoagulants and storage of blood samples on efficacy of the polymerase chain reaction assay for hepatitis $\mathrm{C}$ virus. J Clin Microbiol 30:750-3. 


\section{Table I}

PCR primers used in NS5B-based in house methods

\begin{tabular}{|c|c|c|c|c|}
\hline $\begin{array}{l}\text { Primer } \\
\text { name }\end{array}$ & Genotype & Sequence & $\begin{array}{l}\text { Product } \\
\text { bp }\end{array}$ & $\begin{array}{l}\text { Position } \\
\text { Region } \\
\text { NS5B }\end{array}$ \\
\hline NS5B2F & All & 5'-TTCACGGAGGCTATGACYAGG-3' & $688 \mathrm{bp}$ & $1017-1038$ \\
\hline $\begin{array}{l}\text { NS5B-2R } \\
\text { F56_1-3 } \\
\text { R561-3 }\end{array}$ & $\begin{array}{l}\text { genotypes } \\
1 \text { and } 3\end{array}$ & $\begin{array}{c}\text { 5'-CGGGCATGMGACASGCTGTGA-3' } \\
\text { 5'-CACACTCCAGTYAAYTCCTGG-3' } \\
\text { 5'-CWMCTGGAGAGTAACTGTGGAG-3' }\end{array}$ & $241 b p$ & $\begin{array}{l}1704-1683 \\
1204-1224 \\
1444-1423\end{array}$ \\
\hline $\begin{array}{l}\text { GEN2FSN } \\
\text { GEN2RSN }\end{array}$ & 2 & $\begin{array}{l}\text { 5'-GAC ACT CCC CTG TCA ATT CWT GG-3' } \\
\text { 5'-TG GTY CAG AGT GTC YTG GGC-3' }\end{array}$ & $120 \mathrm{bp}$ & $\begin{array}{l}1202-1224 \\
1321-1313\end{array}$ \\
\hline
\end{tabular}

Tabel II

Comparison of HCV genotyping results obtained with the LiPA (5ÙTR) and the NS5B sequencing

\begin{tabular}{|c|c|c|c|c|c|c|c|c|c|}
\hline \multirow{2}{*}{$\begin{array}{l}\text { LiPA } \\
\text { type }\end{array}$} & \multicolumn{9}{|c|}{ No. of specimens with NS5B sequencing } \\
\hline & $1 a$ & $1 \mathrm{~b}$ & $2 \mathrm{a}$ & $2 b$ & $2 \mathrm{c}$ & $3 a$ & $4 a$ & $5 a$ & Total \\
\hline 1 & 20 & 2 & & & & & & & 22 \\
\hline $1 \mathrm{a}$ & $13^{*}$ & 1 & & & & & & & 14 \\
\hline $1 b$ & 3 & $47^{*}$ & & & & & & & 50 \\
\hline $1 \mathrm{a} / 1 \mathrm{~b}$ & 5 & 3 & & & & & & & 8 \\
\hline 1and3 & 1 & & & & & 2 & & & 3 \\
\hline 2 & & & 1 & 11 & 7 & & & & 19 \\
\hline $2 b$ & & & & $\mathbf{9}^{*}$ & & & & & 9 \\
\hline $2 \mathrm{a} / 2 \mathrm{c}$ & & & & & 2 & & & & 2 \\
\hline $3 a$ & & & & & & $34^{*}$ & & & 34 \\
\hline $3 a / 3 b$ & & & & & & 1 & & & 1 \\
\hline 4 & & & & & & & 1 & & 1 \\
\hline 5 & & & & & & & & 1 & 1 \\
\hline Total & 42 & 53 & 1 & 20 & 9 & 37 & 1 & 1 & 164 \\
\hline
\end{tabular}


Table III

Clinical samples with incomplete, undefined results, discordant subtypes, and mixtures of genotypes by LiPA (5 UTR) and NS5B sequencing

\begin{tabular}{|c|c|c|c|c|}
\hline \multirow{2}{*}{$\begin{array}{l}\text { No. of } \\
\text { samples }\end{array}$} & \multicolumn{3}{|c|}{ LiPA(5’UTR) } & \multirow{2}{*}{$\begin{array}{c}\text { NS5B } \\
\text { sequencing }\end{array}$} \\
\hline & $\begin{array}{l}\text { Incomplete } \\
\text { results*or undefined }\end{array}$ & discordant results & $\begin{array}{l}\text { Mixture of } \\
\text { genotypes }\end{array}$ & \\
\hline 20 & 1 & - & - & $1 \mathrm{a}$ \\
\hline 2 & 1 & - & - & $1 b$ \\
\hline 3 & - & $1 b$ & - & $1 a$ \\
\hline 1 & - & $2 a$ & - & $2 c$ \\
\hline 5 & $1 a / 1 b$ & - & - & $1 a$ \\
\hline 3 & $1 a / 1 b$ & - & - & $1 b$ \\
\hline 11 & 2 & - & - & $2 b$ \\
\hline 7 & 2 & - & - & $2 c$ \\
\hline 1 & 2 & - & - & $2 a$ \\
\hline 2 & $2 a / 2 c$ & - & - & $2 c$ \\
\hline 1 & $3 a / 3 b$ & - & - & $3 a$ \\
\hline 1 & 4 & - & - & $4 a$ \\
\hline 1 & 5 & - & - & $5 a$ \\
\hline 2 & - & - & 1 and 3 & $3 a$ \\
\hline 1 & - & - & 1 and 3 & $1 a$ \\
\hline
\end{tabular}

* without subtype discrimination 


\section{ANEXO B}

\section{Hepatitis C Virus Genotyping by Real-Time PCR Based on the NS5B}

\section{Region}

Sueli M. Nakatani ${ }^{1,2}$, Suzane K. Ono-Nita ${ }^{2^{*}}$, Carlos A. Santos ${ }^{3}$, Irina N. Riediger ${ }^{1}$, Marco Aurélio Krieger, ${ }^{4}$ Cesar A. B. Duarte, ${ }^{4}$ Marco Aurélio Lacerda $^{5}$, Alexander Welker Biondo ${ }^{6}$, Marcelo E. Nita ${ }^{2}$, Flair J. Carilho ${ }^{2}$

Laboratório Central do Estado, LACEN-PR, São José dos Pinhais, Paraná, Brazil $^{1}$

Department of Gastroenterology, School of Medicine, University of São Paulo, USP, São Paulo, Brazil ${ }^{2}$

Centro de Genomas, São Paulo, Brazil ${ }^{3}$

Instituto de Biologia Molecular do Paraná, IBMP, Curitiba, Paraná, Brazil ${ }^{4}$

Division of Gastroenterology and Hepatology, Indiana University, Indianapolis, Indiana, USA ${ }^{5}$

Department of Veterinary Medicine, Federal University of Paraná,Brazil; and Department of Pathobiology, University of Illinois, USA ${ }^{6}$

Running Title: HCV GENOTYPING BY REAL-TIME PCR

* Corresponding author: Dr. Suzane Kioko Ono-Nita, Department of Gastroenterology - School of Medicine - University of São Paulo, São Paulo. 255 ICHC 9o andar sala 9159, Hospital das Clínicas da Faculdade de Medicina, Universidade de São Paulo, Av. Dr. Enéas Carvalho de Aguiar, Jardim América, São Paulo, SP - Brazil 05403-000 - Phone: +55 (11) 30687830 Fax: +55 (11) 3069-8237, Email: skon@usp.br 


\section{ABSTRACT}

Hepatitis $\mathrm{C}$ virus ( $\mathrm{HCV}$ ) genotyping is the most significant predictor of the response to antiviral therapy. The aim of this study was to develop and evaluate a novel real-time PCR method for HCV genotyping based on the NS5B region. Two triplex reaction sets were designed, one to detect genotypes 1a, 1b and 3a; and another to detect $2 \mathrm{a}, 2 \mathrm{~b}$, and $2 \mathrm{c}$. This approach detected $183 / 187(97.8 \%)$ of genotype 1 samples, $31 / 36(86.11 \%)$ of genotype 2 , and $80 / 80(100 \%)$ of genotype 3 , with an overall sensitivity of $294 / 304$ samples (96.7\%). All samples genotyped by real-time PCR had the same type that was assigned using LiPA (Line in Probe Assay). Although the genotyping results for LiPA and real-time PCR differed at the subtype level in 73/304 samples $(24.0 \%)$, NS5B sequencing and real-time PCR results agreed in all 146 cases. Analytical sensitivity of the real-time PCR assay was determined by end-point dilution of the $5000 \mathrm{IU} / \mathrm{ml}$ member of the OptiQuant HCV RNA panel. The lower limit of detection was estimated to be $125 \mathrm{IU} / \mathrm{ml}$ for genotype 3a, $250 \mathrm{IU} / \mathrm{ml}$ for genotype $1 \mathrm{~b}$ and $2 \mathrm{~b}$, and $500 \mathrm{IU} / \mathrm{ml}$ for genotype 1a.

The total time required for this assay was two hours, compared to four hours required for LiPA after PCR-amplification. Furthermore, the estimated reaction cost was nine times lower than that of available commercial methods in Brazil. Thus, we have developed an efficient, feasible, and affordable method for HCV genotype identification. 


\section{INTRODUCTION}

Hepatitis $\mathrm{C}$ virus (HCV) genotyping is reported to be the primary tool for assessing the course of infection and determining treatment duration (72). Several methods based on different HCV genomic regions have been used for determining genotype (92). Most commercial methods are based on the 5' untranslated region ( $5^{\prime} \mathrm{UTR}$ ), which is the region of choice for qualitative and quantitative HCV RNA detection because of its strong conservation among different subtypes. The 5' UTR, however, does not allow sufficient discrimination between closely related subtypes within the same genotype. Subtyping is particularly useful for investigating infection outbreaks and for better understanding the epidemiological and virological features of $\mathrm{HCV}$ (35). In addition, accurate subtyping is important for future studies aiming to develop new drugs and to increase our understanding of how HCV becomes resistant to therapies (84).

Sequencing of an appropriate coding region, such as NS5B, core, or E1 is the gold standard for discriminating HCV types and subtypes (38). Despite of the usefulness of this approach, sequencing is a laborious technique and typically requires several sample handling steps. This increases turnaround time, impairing patient diagnosis and treatment.

Methods such as real-time PCR are more specific and sensitive because they simultaneously use probes and primers to detect target sequences (96). Moreover, this technique is performed on an automated platform without the need for post-PCR procedures, thus minimizing crosscontamination between samples and accelerating the analysis. The aim of 
this study was to develop, standardize, and validate a method for identifying HCV genotypes by real time PCR based on the analysis of the HCV NS5B region.

\section{MATERIALS AND METHODS}

\section{Sample selection}

Ethylenediaminetetraacetic acid (EDTA) plasma was collected between January 2005 and February 2008 from 304 patients chronically infected with HCV who were admitted to the Paraná State Reference Laboratory of Health (LACEN-PR) and the Clinical Hospital at the University of São Paulo. Plasma was stored at $-70^{\circ} \mathrm{C}$ until use. Sample selection was based on infecting genotype, which had been previously determined using the Versant ${ }^{\mathrm{TM}} \mathrm{HCV}$ genotype Assay -LiPA (version I; Siemens Medical Solutions, Diagnostics Division, Fernwald, Germany).

Real-time PCR precision was assessed by testing three randomly selected clinical samples. Sixteen replicates of each sample were analyzed on three different days.

Analytical sensitivity was investigated using the genotype $1 \mathrm{~b}$ OptiQuant ${ }^{\circledR}$ HCV RNA Quantification Panel (Acrometrix, Benicia, CA, USA). The panel member containing $5000 \mathrm{IU} / \mathrm{ml}$ was diluted in negative human plasma to $1000,500,250$, and $125 \mathrm{IU} / \mathrm{ml}$. Relative sensitivity was determined for genotypes $1 \mathrm{a}, 2 \mathrm{~b}$, and $3 \mathrm{a}$ by analyzing clinical specimens. Based on the HCV viral load determined by the Cobas Amplicor® HCV Test (version 2.0; Roche, Branchburg, NJ, USA), each specimen was diluted to 500,250 , and $125 \mathrm{IU} / \mathrm{ml}$. Eight replicates of each dilution were analyzed. 
Specificity was assessed by testing 53 samples from healthy blood donors provided by the Blood Bank at the Clinical Hospital at University of São Paulo). Detection of false-positives was assessed using 40 samples from patients admitted to LACEN-PR for diseases unrelated to HCV. Those samples tested negative for HCV RNA in the Amplicor® HCV Test (version 2.0; Roche, Branchburg, NJ, USA).

\section{RNA extraction}

A total of $200 \mu \mathrm{l}$ of EDTA plasma was extracted from each patient sample using the automated platform Nuclisens easyMAG (bioMérieux, Boxtel, Netherlands) according to the manufacturer's instructions. The RNA was eluted in $60 \mu$ of elution buffer.

\section{Real-time PCR genotyping}

Primers were designed to anneal to conserved sites within the NS5B region and probes were designed to target the internal polymorphic positions in this genomic region. Oligonucleotide design was based on the analysis of data provided by the Los Alamos National Laboratory (http://hcv.lanl.gov/components/hcv-

db/GET ALIGNMENTS/get alignment.comp).

One primer pair and three different probes labeled with different fluorophores were designed to amplify and detect genotypes 1a, 1b, and 3a. An equivalent strategy was used to detect genotypes $2 \mathrm{a}, 2 \mathrm{~b}$, and $2 \mathrm{c}$. Sequences, locations and specificities of primers and probes are shown in Table 1. Oligonucleotide melting temperatures were calculated using Primer Express (Applied Biosystems, Foster, CA, USA). 


\section{Modified one-step real-time PCR}

Reactions were performed in a final volume of $50 \mu \mathrm{l}$ using the Superscript $^{\mathrm{TM}}$ III Platinum ${ }^{\circledR}$ one-step quantitative RT-PCR system (Invitrogen, Carlsbad, CA, USA). The reaction mix was prepared in two fractions. The first fraction ( $F 1)$ consisted of $18.5 \mu$ of $2 X$ reaction mix containing $6 \mathrm{mM}$ $\mathrm{MgSO}_{4}, 0.4 \mathrm{mM}$ of each dNTP, $1.0 \mu \mathrm{l}$ of Taq mix (Superscript ${ }^{\mathrm{TM}}$ III RT, Platinum Taq Mix), 200 nM of reverse primer (R56_1-3 or gen2RSN), and $0.5 \mu \mathrm{l}$ of RNase Out (Invitrogen, Carlsbad, CA, USA). The total volume of the F1 was $21 \mu \mathrm{l}$, which was transferred to the optical tubes. The second reaction mix fraction (F2) consisted of $4.4 \mu$ of $2 X$ reaction mix, $200 \mathrm{nM}$ of forward primer (F56_1-3 or gen2FSN), $1.5 \mu \mathrm{l}$ of $50 \mathrm{mM} \mathrm{MgSO}_{4}, 0,1 \mu \mathrm{l}$ of $\mathrm{ROX}$ $(25 \mu \mathrm{M})$, and $200 \mathrm{nM}$ of each probe (against either genotypes 1a, 1b, and 3a; or against genotypes $2 \mathrm{a}, 2 \mathrm{~b}$, and $2 \mathrm{c}$ ). The final volume of $\mathrm{F} 2$ was $10 \mu \mathrm{l}$, and it was transferred to the caps of the optical tubes. After the addition of $19 \mu$ l of RNA, the optical tubes (containing F1) were carefully covered with the caps (containing F2). Reverse transcription was carried out in a GeneAmp PCR System 9700 (Applied Biosystems, Foster, CA, USA) for 35 min at 50 ${ }^{\circ} \mathrm{C}$ with the cover open. Tubes were briefly spin down and real-time PCR was carried out in a 7500 Real-Time PCR System (Applied Biosystems, Foster, CA, USA) using the following parameters: 2 min at $50^{\circ} \mathrm{C} ; 10$ min at $95^{\circ} \mathrm{C} ; 40$ cycles of $15 \mathrm{~s}$ at $95^{\circ} \mathrm{C}, 30 \mathrm{~s}$ at $50^{\circ} \mathrm{C}$; and $1 \mathrm{~min}$ at $60^{\circ} \mathrm{C}$ (for set $1 \mathrm{a}, 1 \mathrm{~b}$, and 3a) or $15 \mathrm{~s}$ at $95^{\circ} \mathrm{C}$ and $1 \mathrm{~min}$ at $60^{\circ} \mathrm{C}$ (for set $2 \mathrm{a}, 2 \mathrm{~b}$, and $2 \mathrm{c}$ ) (see Figure 1). 


\section{One-step real-time PCR}

Reactions were performed with the same concentrations of reagents and cycling parameters described above, with a final reaction volume of 50 $\mu$, except that the reaction mix was prepared in a single fraction rather than two.

\section{Two-step real-time PCR}

Reactions were performed using a final volume of $25 \mu \mathrm{l}$ and $12.5 \mu \mathrm{l}$ of TaqMan® Universal Master Mix (Applied Biosystems, Foster, CA, USA), $200 \mathrm{nM}$ of the primers F56 1-3 and R56 1-3, $200 \mathrm{nM}$ of each probe, $5 \mu$ of ultra-pure water, and $5 \mu \mathrm{l}$ of cDNA. Reactions were amplified as described above.

\section{Partial sequencing of HCV NS5B region}

To verify the accuracy of the PCR reactions, 146 of the 304 samples were sequenced. Reverse transcription was performed essentially as previously described (157) using $300 \mathrm{U}$ of Moloney Murine Leukemia Virus RT (MMLV-RT; Invitrogen, Carlsbad, CA, USA) and $7.5 \mathrm{ng} / \mu \mathrm{l}$ of random primer (cat. \# 48190-011; Invitrogen, Carlsbad, CA, USA).

Table I includes details of the primers (Invitrogen, Carlsbad, CA, USA) used for PCR amplification of the NS5B region. Each $\mathrm{PCR}$ reaction contained buffer [10X concentrations: $200 \mathrm{mM}$ Tris- $\mathrm{HCl}(\mathrm{pH}$ 8.4), $500 \mathrm{mM}$ $\mathrm{KCl}$ ], $1.5 \mathrm{mM} \mathrm{MgCl}_{2}, 200 \mathrm{nM}$ of each dNTP, $1 \mu \mathrm{M}$ of each primer, $2.5 \mathrm{IU}$ of High Fidelity Taq DNA polymerase (Invitrogen, Carlsbad, CA, USA), and $5 \mu$ l of cDNA to be tested. The final volume was adjusted to $50 \mu \mathrm{l}$ using DEPCtreated $\mathrm{H}_{2} \mathrm{O}$. PCR was carried out using a GeneAmp PCR System 9700 
(Applied Biosystems, Foster, CA, USA) and the following amplification conditions: 5 min at $94^{\circ} \mathrm{C}$; 35 cycles at $95^{\circ} \mathrm{C}$ for $30 \mathrm{~s}, 60.5^{\circ} \mathrm{C}$ for 1 min for primers NS5B2F/NS5B2R or $56{ }^{\circ} \mathrm{C}$ for 45 s for primers F56_1-3/R56_1-3, 72 ${ }^{\circ} \mathrm{C}$ for $1 \mathrm{~min} ; 10 \mathrm{~min}$ at $72{ }^{\circ} \mathrm{C}$ and a final hold at $10^{\circ} \mathrm{C}$.

Sequencing reactions were performed in both directions using Big Dye terminator technology (version 3.2; Applied Biosystems, Foster, CA, USA) and products were detected with an ABI 3130 Genetic Analyzer (Applied Biosystems, Foster, CA, USA). Sequencing analysis was performed using SeqScape (Applied Biosystems, Foster, CA, USA), and genotypes were assigned by matching using Blast (http://blast.ncbi.nlm.nih.gov/Blast.cgi).

The generated sequences were submitted to GenBank and can be retrieved under accession numbers FJ159697 to FJ159843.

\section{Phylogenetic analysis}

An internal fragment of 216 nucleotides within the PCR products generated for sequencing (positions 1223-1438 in the NS5B region according to the reference sequence $\mathrm{H} 77$, accession NC004102) was used for phylogenetic analysis. Nucleotide distances were computed on MEGA version 4.0 (133) by the $\rho$-distance algorithm and phylogenetic trees were inferred using the neighbor joining method. Robustness of tree branches was tested by bootstrap analysis (1000 replicates).

\section{Statistical analysis}

Consistency between real time PCR and LiPA was assessed using the $\kappa$ coefficient, with $\kappa$ values between 0.61 and 0.80 taken to indicate good 
concordance (136), when both methods classified specimens into the same categories (genotypes or subtypes). Statistical analysis was performed using Program R for Windows (version 2.7.0). Concord software was used to calculate agreement between techniques. A p value less than 0.05 was considered significant.

\section{RESULTS}

\section{Real-Time PCR genotyping validation tests}

The first validation tests were performed using the two-step system, but the results were inconsistent. In order to compare the performance of the one-step and modified one-step methods, seven clinical specimens infected with different genotypes were tested. The mean number of threshold cycles (Ct's) for the one-step method was $34.18 \pm 4.0$ and $28.82 \pm 3.2$ for the modified one-step method. Therefore, all subsequent validation tests were carried out using the modified one-step method.

\section{Accuracy}

Results obtained for all the 146 samples genotyped by real-time PCR and partial sequencing of the NS5B region showed $100 \%$ consistency. No discrepancies were found using phylogenetic analysis or matching with Blast.

\section{Reproducibility}

Assays were performed for genotypes $1 \mathrm{a}, 1 \mathrm{~b}$, and $3 \mathrm{a}$ on three different days with 16 replicates $(n=48)$. The total coefficient of variation of the Ct was $2.67 \%$ for genotype $3 a$ (mean Ct, $27.49 \pm 0.73$ ), 6.25\% for genotype $1 \mathrm{~b}$ (mean $\mathrm{Ct}, 26.54 \pm 1.66$ ), and $6.40 \%$ for genotype $1 \mathrm{a}$ (mean Ct, $27.65 \pm 1.73)$ 


\section{Analytical sensitivity}

Real-time PCR genotyping was determined by analyzing the Optiquant ${ }^{\circledR}$ HCV RNA Quantification Panel (Acrometrix, Benicia, CA, USA). The limit of detection was determined as the lowest concentration needed to provide genotype identification with a detection rate of at least $95 \%$. A $95 \%$ detection limit was measured at $250 \mathrm{IU} / \mathrm{ml}$ in 24 replicates.

\section{Relative sensitivity}

Relative sensitivity was estimated by analyzing clinical specimens from patients infected with genotypes $1 a, 2 b$, or $3 a$. A $95 \%$ detection limit of $500 \mathrm{IU} / \mathrm{ml}$ was measured for genotype $1 \mathrm{a}, 250 \mathrm{IU} / \mathrm{ml}$ for genotype $2 \mathrm{~b}$, and $125 \mathrm{IU} / \mathrm{ml}$ for genotype 3 a.

\section{Specificity}

To determine the specificity of the primer-probe sets used for real-time PCR genotyping, 53 samples were tested. None of the samples showed falsepositive reactions.

\section{Analytical specificity}

The genotype-specific primer-probe sets - one against $1 \mathrm{a}, 1 \mathrm{~b}$, and $3 a$, and the other against $2 a, 2 b$, and $2 c$ - were evaluated with other genotypes of HCV available in our laboratory, such as $4 a$ and $5 a$. No false positive results were obtained when these genotypes were tested.

\section{Genotype mixtures}

To determine whether the presence of multiple HCV genotypes in one sample interferes with the specificity of the assay, we artificially mixed 
RNA from different HCV genotypes. One sample of genotype 1a $(550,000$ $\mathrm{IU} / \mathrm{ml})$ and a sample of genotype 3a $(559,000 \mathrm{IU} / \mathrm{ml})$ were prepared and mixed in different volume proportions, e.g. 1:1, 1:5, and 1:10 for $1 \mathrm{a}$ and $3 \mathrm{a}$ and vice versa. Both genotypes $1 \mathrm{a}$ and $3 \mathrm{a}$ were correctly detected in all the mixtures prepared.

\section{False positive detection}

To assess possible false positive detection by the genotype-specific primer-probe sets, we tested specimens infected with common non-C viral hepatitis: Hepatitis B Virus $(n=10)$, Hepatitis A Virus $(n=10), \operatorname{HIV}(n=10)$, and dengue virus ( $n=10$ ), which belongs to the same family (Flaviviridae) as HCV . HIV-infected samples were chosen because of the high incidence of HIV-HCV co-infection in this patient population. The genotype primer-probe sets were found to be specific for detection of different genotypes and did not lead to false positive results with the common hepatitis viruses (HAV and HBV), dengue virus or HIV.

\section{Correlation between real-time PCR genotyping and LiPA}

A total of 304 clinical samples was used to compare the real-time PCR genotyping with LiPA (Table 2). Genotyping by real-time PCR correctly identified $97.8 \%(183 / 187)$ of the samples of genotype 1 . Mean Ct's of realtime PCR genotyping for genotype 1a was 26.43 and 27.24 for genotype $1 \mathrm{~b}$. Real-time PCR genotyping also produced results for $31 / 36$ (86.11\%) samples of genotype 2, with mean Ct's of 25.83. Moreover, real-time PCR was able to genotype $80 / 80$ (100\%) samples of genotype 3 with mean Ct's of 26.34 . No discrepancies were observed in a total of 304 samples when comparing real- 
time PCR genotyping and LiPA at the type level. When subtypes were considered, however, we found only a moderate concordance $(0.4800, p=$ 0.0118). When we compared the results of the two methods at the subtype level, we found a misclassification frequency of $24.0 \%(73 / 304)$. From this total, $64 / 79$ (81.01\%) samples were sequenced and the result obtained from real-time PCR genotyping was confirmed.

\section{DISCUSSION}

We have described the development of a novel HCV genotyping method based on real-time PCR that involves two one-step triplex reactions. One reaction serves to detect genotypes $1 \mathrm{a}, 1 \mathrm{~b}$, and $3 \mathrm{a}$; while the other serves to detect $2 \mathrm{a}, 2 \mathrm{~b}$, and $2 \mathrm{c}$. Accuracy, precision, analytical and relative sensitivity, and specificity were investigated in order to validate the method. Performance was evaluated by comparing the genotyping results obtained from real-time PCR with those generated by LiPA and partial NS5B sequencing.

Some studies have reported real-time PCR methods for HCV genotyping. Two studies have described a single-step, real-time, reverse transcription-PCR (RT-PCR) reaction using a genotype-specific TaqMan probe $(107,108))$, LightCycler probes $(1,10,22)$, or SYBR Green detection (112). All these methods focus on the 5' UTR. More recently, a real-time PCR-based method has become commercially available. The assay design of this kit is such that genotypes $1 \mathrm{a}$ and $1 \mathrm{~b}$ are typed by amplification 
targeting in the nonstructural 5B region (NS5B). Other genotypes such as 2 , 3, 4, 5, and 6 are detected through the 5' UTR. Cook (124) compared this commercial method with a restriction fragment polymorphism (RLFP) method, and discrepant samples were sequenced. Results showed the analytical sensitivity to be poor for genotypes $1 \mathrm{a}$ and $1 \mathrm{~b}$, even when these were present at $>1500 \mathrm{UI} / \mathrm{ml}$. In contrast, our method shows a lower limit of detection in the genotype-specific reactions ranging from $125 \mathrm{IU} / \mathrm{ml}$ for genotype 3a, $250 \mathrm{IU} / \mathrm{ml}$ for genotypes $2 \mathrm{~b}$ and 1b, and $500 \mathrm{IU} / \mathrm{ml}$ for genotype 1a. The present genotyping method presented an overall detection rate of 294/304 (96.7\%), which is similar to previously reported PCR-based methods $(15,17)$.

Since HCV is an RNA virus, a critical step in optimizing our method was deciding whether to use a one-step or two-step system for reverse transcription. Optimization of the oligonucleotide concentrations was carried out using two-step-based reactions with MMLV-RT and random primers for reverse transcription; these pilot experiments showed that the optimal primer concentration was $200 \mathrm{nM}$. All other two-step optimization experiments, however, failed to show consistent results (data not shown). Different factors may have contributed to the poor results obtained with the two-step approach. Reverse transcription annealing temperature may influence the formation of RNA secondary structures that directly affect reaction efficiency. Reverse transcriptases which work at low temperatures, such as MMLV RT, may thus lead to low efficient reverse transcriptions (143). The type of primer used in reverse transcription may also affect the reaction efficiency (144). Whereas random primers may generate 
multiple, different cDNA segments from the original RNA and thereby reduce PCR sensitivity, the use of specific primers results in more specific cDNA synthesis, which increases the sensitivity of the real-time PCR (139). Such factors may have contributed to the low efficiency observed in our two-step real-time PCR system, given that we performed reverse transcription with MMLV-RT and random primers.

Another study demonstrated that there is no difference in the relative efficiency of one-step and two-step systems when the expression rate of the target gene is high (142). When the rate of expression is low, however, detection occurred five cycles earlier in the one-step method than in the twostep method. Assuming an amplification efficiency of $100 \%$, this means that the one-step method in that study was 32 -fold more sensitive than the twostep one for detecting the gene. Based on this work, we sought to standardize our method as a one-step system instead of a two-step one. The next step was to choose an enzyme that could work at higher temperatures in the reverse transcription reaction. Different studies show that the choice of enzyme is a key determinant of reaction efficiency $(19,30)$. In our study, we used a one-step kit with Superscript III, a modified version of MMLV-RT that is stable at $45-60^{\circ} \mathrm{C}$; the use of these elevated temperatures reduces the formation of secondary structures and the RNase $\mathrm{H}$ activity associated with the reverse transcriptase (139).

Another important step in optimizing our method was how to incubate the reverse transcription reaction. A one-step reaction was tested in which all reagents, including the extracted RNA, were incubated in the real-time PCR 
machine. Studies have shown that addition of forward primers after the reverse transcription reaction and before activation of Taq polymerase prevents the formation of primer-dimers and results in more efficient amplification (143). We therefore tested a reaction modification in which the reagents were added separately. Some of the reagents were placed in the reaction tube and the remaining reagents, including the forward primer, were placed in the tube caps (Figure 1). The modified one-step method showed earlier amplification (5.6 Ct's on average) than the original one-step method. In addition, by placing the forward primer in the optical cap, the reaction could be carried out without opening the tube, thereby avoiding potential contamination between samples and enabling the reaction to be performed in a single step.

Another focus of the study was the cost-benefit of a reaction in which three probes could be effectively placed in the same tube (triplex reaction). Therefore, a single primer set was designed to amplify genotypes 1a, 1b and 3a. Probes labeled with FAM, VIC and NED, which use different optical reading channels, were used to detect PCR products. An equivalent triplex reaction was set to detect subtypes $2 \mathrm{a}, 2 \mathrm{~b}$, and $2 \mathrm{c}$, and the melting temperature was calculated to be $60 \stackrel{\circ}{\mathrm{C}}$ for primers and $70^{\circ} \mathrm{C}$ for probes.

To increase specificity in the polymorphic NS5B region, we had to design shorter oligonucleotides into the probes of genotypes 1a, 1b, and 3a. Consequently, the estimated melting temperature was $66^{\circ} \mathrm{C}$ for probes and $56{ }^{\circ} \mathrm{C}$ for primers, and an additional cycling step of $50{ }^{\circ} \mathrm{C}$ was added to the real-time PCR. The above types and subtypes were selected because they 
account for $99 \%$ of the HCV-infected population in Brazil (53). In contrast, genotypes 4 and 5 account for $0.3 \%$ of the Brazilian cases (158), and genotype 6 has never been described in Brazil (159), (55). These genotypes were therefore not considered in the assay design.

A recent study of real-time PCR genotyping has proposed extracting RNA from a plasma volume of $1,000 \mu \mathrm{l}$ eluting it into $80 \mu \mathrm{l}$, which corresponds to a 12.5-fold concentration (124). In the present study, because of the limited amount of plasma available to us, we extracted RNA from 200 $\mu \mathrm{l}$ of plasma and eluted it into $60 \mu \mathrm{l}$, corresponding to a 3.3-fold concentration. We compensated for the lower concentration by adding $19 \mu \mathrm{l}$ of RNA to the reaction.

Validation tests confirmed the specificity of our method, both in relation to different genotypes and to the potential presence of a mixed viral population. Our results showed that our method can detect multiple genotypes at all dilutions tested, even when the minor genotype is present at 10-fold lower levels than the other genotype. However, more samples must be analyzed in order to determine the true prevalence of mixed infections in our population.

When we compared HCV genotyping results generated by real-time PCR and LiPA, we found $100 \%$ agreement at the type level. These results are similar to those reported by another study involving 357 samples from blood donors in France, which demonstrated 100\% consistency between 5 UTR and NS5B sequence analysis when classifying types (80). However, genotype identification based on the 5' UTR may pose a problem in some 
geographical regions, because some genotype 6 variants found in Southeast Asia have identical 5' UTR sequences to those of genotypes 1a or 1b (116).

At the subtype level, however, we found a misclassification frequency of $24.0 \%(73 / 304)$ when comparing the genotyping results of realtime PCR and LiPA. This lack of agreement includes cases in which LiPA failed to yield a clear result, as well as cases in which the two methods simply gave different results. In our study, we failed to correctly identify the subtype of $36.8 \%(35 / 95)$ of samples containing genotype 1a using LiPA version I. In particular, the LiPA method misclassified seven samples of genotype $1 \mathrm{a}$ as genotype $1 \mathrm{~b}$. This finding is consistent with other studies that have found that amplifying the 5' UTR overestimates the frequency of subtype 1 b by $20 \%$ at the expense of subtype $1 \mathrm{a}(81)$. Furthermore, we were unable to correctly type eight samples by LiPA, which were misclassified as 1a/1b. Using real-time PCR genotyping, two of these samples were classified as $1 \mathrm{~b}$ and the remaining six as genotype $1 \mathrm{a}$.

Our real-time PCR genotyping method showed high accuracy at the subtype level, but it failed to give amplification products in $3 \%$ of the samples. These results show that targeting a polymorphic region for amplification may limit genotyping success, since potential mutations may reduce the affinity between the target region and the PCR primers and probes.

In addition to its efficiency, our real-time PCR method costs less than commercial methods currently available, when the costs of reagents and laboratory material are taken into account. Another positive feature of our proposed method is its smaller number of sample handling steps and its 
faster turnaround time. The LiPA method requires approximately 16 hours to process, which includes nucleic acid extraction, amplification, detection, hybridization, washings and interpretation. In contrast, our real-time PCR method has a semi-automatic average working time of two hours, and it avoids the constant manual handling steps typical of the LiPA method. Since the system is semi-automated, results can be available the same day, which can significantly improve the laboratory-hospital-patient flow. Another advantage to the method is that it is based on a one-step modified system that allows all reaction steps to be conducted in one straightforward process. This minimizes sample handling, reducing the risk of contamination and error. The triplex reaction, which allows the simultaneous detection of three different genotypes, represents a further methodological gain because it permits faster working time and lower cost per assay. The present method targets the NS5B region, which may be important for epidemiological studies as well as for correlating patient response to current and new drugs as a function of different HCV types and subtypes.

This method may provide more accurate correlation between clinical outcomes and different genotypes and their subtypes, as well as improved understanding of the role of genomic variability on HCV infectiousness and on its demographic pattern of infection.

\section{ACKNOWLEDGEMENTS}

These investigations were supported in part by grants from Secretaria de Saúde do Estado do Paraná, Fundação Araucária and Alves de Queiroz Family Fund for Research. We are indebted to Hermes Pedreira 
da Silva Filho from Centro de Pesquisas Gonçalo Moniz (CPqGM/FIOCRUZ-

Bahia) who performed the phylogenetic analysis.

\section{REFERENCES}

1.Campiotto, S., J. R. Pinho, F. J. Carrilho, L. C. Da Silva, F. J. Souto, V. Spinelli, L. M. Pereira, H. S. Coelho, A. O. Silva, J. C. Fonseca, H. Rosa, C. M. Lacet, and A. P. Bernardini. 2005. Geographic distribution of hepatitis C virus genotypes in Brazil. Braz J Med Biol Res 38:41-9.

2.Cantaloube, J. F., S. Laperche, P. Gallian, F. Bouchardeau, X. de Lamballerie, and P. de Micco. 2006. Analysis of the 5 ' noncoding region versus the NS5b region in genotyping hepatitis $C$ virus isolates from blood donors in France. J Clin Microbiol 44:2051-6.

3.Cook, L., K. Sullivan, E. M. Krantz, A. Bagabag, and K. R. Jerome. 2006. Multiplex real-time reverse transcription-PCR assay for determination of hepatitis C virus genotypes. J Clin Microbiol 44:4149-56.

4.Corbet, S., J. Bukh, A. Heinsen, and A. Fomsgaard. 2003. Hepatitis C virus subtyping by a core-envelope 1-based reverse transcriptase PCR assay with sequencing and its use in determining subtype distribution among Danish patients. J Clin Microbiol 41:1091-100.

5.Davidson, F., P. Simmonds, J. C. Ferguson, L. M. Jarvis, B. C. Dow, E. A. Follett, C. R. Seed, T. Krusius, C. Lin, G. A. Medgyesi, and et al. 1995. Survey of major genotypes and subtypes of hepatitis $C$ virus using RFLP of sequences amplified from the 5' non-coding region. J Gen Virol 76 (Pt 5):1197-204.

6.Fujigaki, H., M. Takemura, K. Takahashi, Y. Yamada, H. Fujii, H. Wada, K. Saito, H. Ohnishi, and M. Seishima. 2004. Genotyping of hepatitis C virus by melting curve analysis with SYBR Green I. Ann Clin Biochem 41:130-2.

7.Holland, P. V., J. M. Barrera, M. G. Ercilla, C. F. Yoshida, Y. Wang, G. A. de Olim, B. Betlach, K. Kuramoto, and H. Okamoto. 1996. Genotyping hepatitis $C$ virus isolates from Spain, Brazil, China, and Macau by a simplified PCR method. J Clin Microbiol 34:2372-8.

8.Kubista, M., J. M. Andrade, M. Bengtsson, A. Forootan, J. Jonak, K. Lind, R. Sindelka, R. Sjoback, B. Sjogreen, L. Strombom, A. Stahlberg, and N. Zoric. 2006. The real-time polymerase chain reaction. Mol Aspects Med 27:95-125.

9.Kusser, W., Javorschi, S. Gleeson, MA. 2006, posting date. Protocol of Real-Time RT-PCR:cDNA synthesis. [Online.]

10.Levi, J. E., D. T. Takaoka, R. H. Garrini, R. M. Fachini, R. Focaccia, E. De Bortholi Santos, H. P. Mitre, J. S. De Mendonca, N. De Paula Cavalheiro, A. A. Barone, and S. Wendel. 2002. Three cases of infection with hepatitis $\mathrm{C}$ virus genotype 5 among Brazilian hepatitis patients. J Clin Microbiol 40:2645-7. 
11.Lindh, M., and C. Hannoun. 2005. Dynamic range and reproducibility of hepatitis $B$ virus (HBV) DNA detection and quantification by Cobas Taqman HBV, a real-time semiautomated assay. J Clin Microbiol 43:4251-4.

12.Murphy, D. G., B. Willems, M. Deschenes, N. Hilzenrat, R. Mousseau, and S. Sabbah. 2007. Use of sequence analysis of the NS5B region for routine genotyping of hepatitis $C$ virus with reference to $C / E 1$ and $5^{\prime}$ untranslated region sequences. J Clin Microbiol 45:1102-12.

13.Peters, I. R., C. R. Helps, E. J. Hall, and M. J. Day. 2004. Real-time RTPCR: considerations for efficient and sensitive assay design. J Immunol Methods 286:203-17.

14.Poynard, T., P. Marcellin, S. S. Lee, C. Niederau, G. S. Minuk, G. Ideo, V. Bain, J. Heathcote, S. Zeuzem, C. Trepo, and J. Albrecht. 1998. Randomised trial of interferon alpha2b plus ribavirin for 48 weeks or for 24 weeks versus interferon alpha2b plus placebo for 48 weeks for treatment of chronic infection with hepatitis $\mathrm{C}$ virus. International Hepatitis Interventional Therapy Group (IHIT). Lancet 352:1426-32.

15.Rolfe, K. J., G. J. Alexander, T. G. Wreghitt, S. Parmar, H. Jalal, and M. D. Curran. 2005. A real-time Taqman method for hepatitis $C$ virus genotyping. J Clin Virol 34:115-21.

16.Silva, C. M., C. Costi, L. P. Krug, A. B. Ramos, T. Grandi, V. L. Gandolfi, M. E. Menezes, M. Ocampos, C. Niel, and M. L. Rossetti. 2007. High proportion of hepatitis $C$ virus genotypes 1 and 3 in a large cohort of patients from Southern Brazil. Mem Inst Oswaldo Cruz 102:867-70.

17.Simmonds, P. 2004. Genetic diversity and evolution of hepatitis C virus-15 years on. J Gen Virol 85:3173-88.

18.Simmonds, P., A. Alberti, H. J. Alter, F. Bonino, D. W. Bradley, C. Brechot, J. T. Brouwer, S. W. Chan, K. Chayama, D. S. Chen, and et al. 1994. A proposed system for the nomenclature of hepatitis $C$ viral genotypes. Hepatology 19:1321-4.

19.Stahlberg, A., J. Hakansson, X. Xian, H. Semb, and M. Kubista. 2004. Properties of the reverse transcription reaction in mRNA quantification. Clin Chem 50:509-15.

20.Stahlberg, A., M. Kubista, and M. Pfaffl. 2004. Comparison of reverse transcriptases in gene expression analysis. Clin Chem 50:1678-80.

21.Tamura, K., J. Dudley, M. Nei, and S. Kumar. 2007. MEGA4: Molecular Evolutionary Genetics Analysis (MEGA) software version 4.0. Mol Biol Evol 24:1596-9.

22.Thompson, W. D., and S. D. Walter. 1988. Kappa and the concept of independent errors. J Clin Epidemiol 41:969-70.

23.Wacker, M. J., and M. P. Godard. 2005. Analysis of one-step and twostep real-time RT-PCR using SuperScript III. J Biomol Tech 16:266-71.

24.Weck, K. 2005. Molecular methods of hepatitis C genotyping. Expert Rev Mol Diagn 5:507-20. 


\section{FIGURE LEGENDS}

Figure 1. Schematic view of modified one-step real-time PCR. The reaction mix was prepared in two fractions, in tubes and caps.

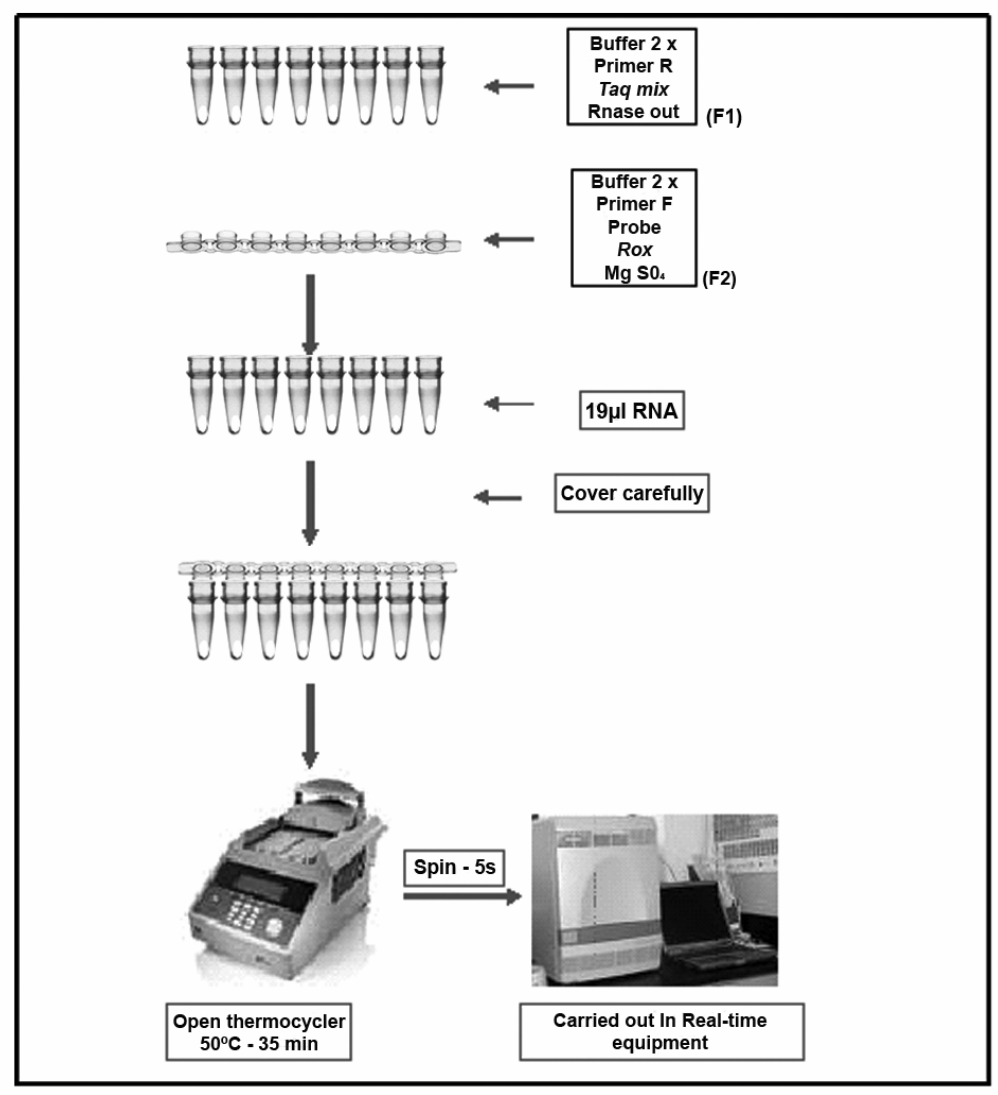


Table 1 Primers and Probes used in Real-Time PCR genotyping of NS5B region

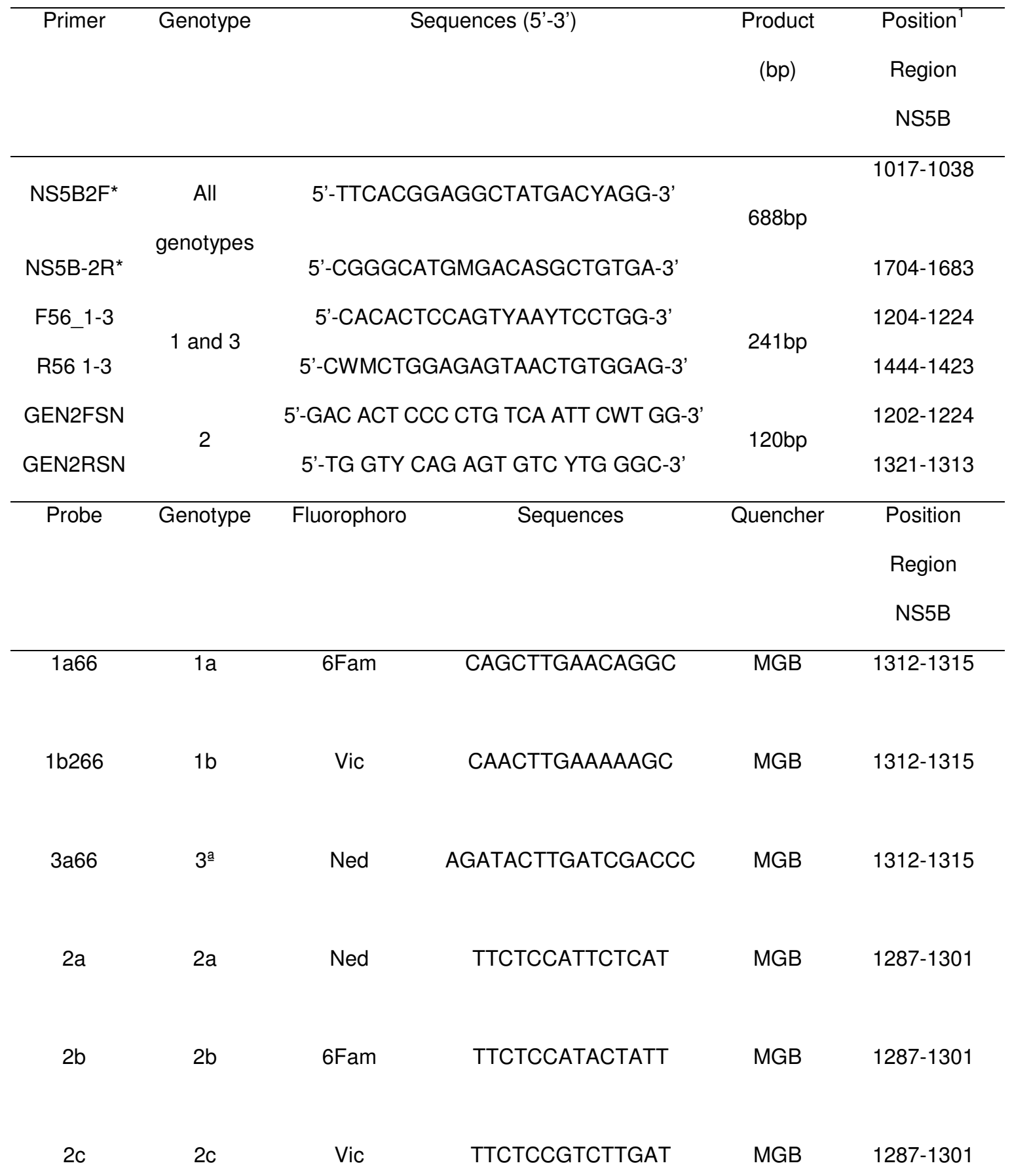

\footnotetext{
${ }^{1} 1$ a_H77.NC_004102 - reference sequence to calculate position of NS5B region. *NS5B2F/NS5B 2 R used only in NS5B sequencing
} 
Table 2 Comparison of HCV genotyping results with LiPA(5'UTR) and RealTime PCR genotyping (NS5B)

\begin{tabular}{|c|c|c|c|c|c|c|c|c|}
\hline \multirow[t]{2}{*}{ LiPA(5’UTR) } & \multicolumn{8}{|c|}{ Real-time PCR genotyping (NS5B) } \\
\hline & $1 \mathrm{a}$ & $1 b$ & $2 a$ & & $2 b$ & $2 c$ & $3 a$ & Negative \\
\hline 1 & 35 & 7 & & & & & & 1 \\
\hline $1 a$ & $47^{1}$ & 5 & & & & & & \\
\hline $1 b$ & 7 & $75^{1}$ & & & & & & 3 \\
\hline $1 \mathrm{a} / 1 \mathrm{~b}$ & 6 & 2 & & & & & & \\
\hline 2 & & & & 1 & 14 & & & 4 \\
\hline $2 a / 2 c$ & & & & & & 3 & & 1 \\
\hline $2 b$ & & & & & $13^{1}$ & & & \\
\hline $3 a$ & & & & & & & $80^{1}$ & \\
\hline & 95 & 89 & & 1 & 27 & 3 & 80 & 9 \\
\hline
\end{tabular}


ANEXO C

protocolo de registro

\begin{tabular}{|lc|}
\hline & GENOTIPAGEM DO VHC POR PCR EM TEMPOR REAL \\
\hline Data: & Operador: \\
\hline
\end{tabular}

\begin{tabular}{|l|l|l|l|l|l|l|l|l|} 
lote: & & & & & & & & \\
\hline A & & & & & & & & \\
\hline B & & & & & & & & \\
\hline C & & & & & & & & \\
\hline D & & & & & & & & \\
\hline E & & & & & & & & \\
\hline F & & & & & & & & \\
\hline G & & & & & & & & \\
\hline H & & & & & & & & \\
\hline
\end{tabular}

\begin{tabular}{l|r|}
\hline \multicolumn{2}{c|}{ MASTER MIX } \\
\hline Tampão 2X & 18,5 \\
Pirmer R Gen 561-3 & 1 \\
Taq mix & 1 \\
Rnaseout & 0,5 \\
\hline \multicolumn{2}{|c}{ Distribuir 21 ul nos tubos } \\
\hline \multicolumn{2}{|c|}{ TRIPLEX } \\
\hline Tampão 2X & 4,5 \\
Primer F gen 56 1-3 & 1 \\
MgSO $_{4}$ & 1,5 \\
sonda 1a,1b,3a cada & 1 \\
\hline Rox Distribuir 10ul do mix nas tampas \\
\hline \multicolumn{2}{c}{0,1} \\
Acrescentar 19 ul de RNA extraído nos tubos
\end{tabular}




\section{ANEXO D \\ aprovação no Comitê de Ética}

\section{rí.}

\section{APROVACÃO}

A Comissão de Ética para Análise de Projetos de Pesquisa - CAPPesq da Diretoria Clínica do Hospital das Clínicas e da Faculdade de Medicina da Universidade de São Paulo, em sessão de 14.09.05, APROVOU o Protocolo de Pesquisa $n^{\circ}$ 586/05, intitulado: "Genotipagem do vírus da hepatite $C$ por análise da região NS5B pela técnica da PCR em tempo real" apresentado pelo Departamento de GASTROENTEROLOGIA

$$
\text { Cabe ao pesquisador elaborar e apresentar à }
$$

CAPPesq, os relatórios parciais e final sobre a pesquisa (Resolução do Conselho Nacional de Saúde $n^{\circ} 196$, de 10.10.1996, inciso IX. 2, letra "c")

Pesquisador(a) Responsável: Dra. Suzane Kioko Ono-Nita

Pesquisador (a) Executante: Sra. Sueli Massumi Nakatani

CAPPesq, 14 de Setembro de 2005.

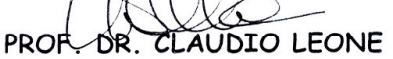

Vice-Presidente da Comissão de Ética para Análise de Projetos de Pesquisa

Comissão de Ética para Análise de Projetos de Pesquisa do HCFMUSP e da FMUSP Clínica do Hospital das Clinicas da Faculdade de Medicina da Universidade de São Paulo Rua Ovídio Pires de Campos. 225, $5^{\circ}$ andar - CEP 05430010 - São Paulo - SP 


\section{REFERÊNCIAS}

1. World Health Organization. Hepatitis C global prevalence (update) Weekly Epidemiological Record. In; 1999. p. 425.

2. Brasil, Ministério da Saúde. Portaria ํo 34 , de 28 de setembro de 2007. In: Secretaria de Vigilância em Saúde; 2007.

3. Hoofnagle JH. Course and outcome of hepatitis C. Hepatology 2002;36(5 Suppl 1):S21-9.

4. Seeff LB. Natural history of chronic hepatitis C. Hepatology 2002;36(5 Suppl 1):S35-46.

5. Pawlotsky JM. The nature of interferon-alpha resistance in hepatitis $\mathrm{C}$ virus infection. Curr Opin Infect Dis 2003;16(6):587-92.

6. Pawlotsky JM. Pathophysiology of hepatitis $C$ virus infection and related liver disease. Trends Microbiol 2004;12(2):96-102.

7. Bacon BR, McHutchison JG. Into the light: strategies for battling hepatitis C. Am J Manag Care 2007;13 Suppl 12:S319-26.

8. Choo QL, Kuo G, Weiner AJ, Overby LR, Bradley DW, Houghton M. Isolation of a cDNA clone derived from a blood-borne non- $A$, non-B viral hepatitis genome. Science 1989;244(4902):359-62.

9. Thiel H. in: Virus taxonomy VIIlth Report of the International Committee on Taxonomy of Viruses: Academic Press; 2005.

10. Penin F, Dubuisson J, Rey FA, Moradpour D, Pawlotsky JM. Structural biology of hepatitis C virus. Hepatology 2004;39(1):5-19.

11. Wakita T, Pietschmann T, Kato T, Date T, Miyamoto M, Zhao Z, et al. Production of infectious hepatitis $C$ virus in tissue culture from a cloned viral genome. Nat Med 2005;11(7):791-6.

12. Pileri P UY, Campagnoli S, Galli G, Falugi F, Petracca R. Binding of hepatitis C virus to CD81. Science 1998;282:938-941.

13. Scarselli E, Ansuini H, Cerino R, Roccasecca RM, Acali S, Filocamo $G$, et al. The human scavenger receptor class $B$ type $I$ is a novel candidate receptor for the hepatitis C virus. Embo J 2002;21(19):501725.

14. Evans MJ, Rice CM, Goff SP. Phosphorylation of hepatitis C virus nonstructural protein $5 \mathrm{~A}$ modulates its protein interactions and viral RNA replication. Proc Natl Acad Sci U S A 2004;101(35):13038-43. 
15. Andre P, Perlemuter G, Budkowska A, Brechot C, Lotteau V. Hepatitis $C$ virus particles and lipoprotein metabolism. Semin Liver Dis 2005;25(1):93-104.

16. Evans MJ, von Hahn T, Tscherne DM, Syder AJ, Panis M, Wolk B, et al. Claudin-1 is a hepatitis $C$ virus co-receptor required for a late step in entry. Nature 2007;446(7137):801-5.

17. Tscherne DM, Jones CT, Evans MJ, Lindenbach BD, McKeating JA, Rice CM. Time- and temperature-dependent activation of hepatitis C virus for low-pH-triggered entry. J Virol 2006;80(4):1734-41.

18. Modis Y, Ogata S, Clements D, Harrison SC. Structure of the dengue virus envelope protein after membrane fusion. Nature 2004;427(6972):313-9.

19. Moradpour D, Penin F, Rice CM. Replication of hepatitis C virus. Nat Rev Microbiol 2007;5(6):453-63.

20. Tanaka T, Kato N, Cho MJ, Sugiyama K, Shimotohno K. Structure of the $3^{\prime}$ terminus of the hepatitis $\mathrm{C}$ virus genome. J Virol 1996;70(5):3307-12.

21. kolykhalov AA MK, Feinstone SM, Rice CM. Hepatitis Cvirus-encoded enzimatic activities and conserved RNA elements in the 3 'nontranslated region are essential by virus replcation in vivo. J Virol 2000;74:2046-2051.

22. Spahn CM KJ, Grauucci RA, Penczek PA, Zhou K, Doudna JA, Frank J. Hepatitis $C$ virus IRES RNA-induced changes in the conformation of the 40S ribosomal subunit. Science 2001;291:1959-1962.

23. Otto GA, Puglisi JD. The pathway of HCV IRES-mediated translation initiation. Cell 2004;119(3):369-80.

24. Asselah T, Rubbia-Brandt L, Marcellin P, Negro F. Steatosis in chronic hepatitis C: why does it really matter? Gut 2006;55(1):123-30.

25. Op De Beeck A VC, Bartosch B, Ciczora Y, Cocquerel L, Keck Z, Foung S, Cosset FL, Dubuisson J. Characterization of functional hepatitis C virus envelope glycoproteins. J Virol 2004;78:2994-3002.

26. Dubuisson J, Penin F, Moradpour D. Interaction of hepatitis C virus proteins with host cell membranes and lipids. Trends Cell Biol 2002;12(11):517-23. 
27. Yanagi M SCM, Emerson SU, Purcell RH, Bukh J. In vivo analysis of the 3 untranslated region of te hepatitis $C$ virus after in vitro mutagenesis of an infectious cDNA clone. Proc. Natl Acade. Sci. 1999;96:2291-2295.

28. Griffin SD, Beales LP, Clarke DS, Worsfold O, Evans SD, Jaeger J, et al. The $p 7$ protein of hepatitis $C$ virus forms an ion channel that is blocked by the antiviral drug, Amantadine. FEBS Lett 2003;535(13):34-8.

29. Yamaga AK, Ou JH. Membrane topology of the hepatitis $\mathrm{C}$ virus NS2 protein. J Biol Chem 2002;277(36):33228-34.

30. Wolk B, Sansonno D, Krausslich HG, Dammacco F, Rice CM, Blum $\mathrm{HE}$, et al. Subcellular localization, stability, and trans-cleavage competence of the hepatitis $C$ virus NS3-NS4A complex expressed in tetracycline-regulated cell lines. J Virol 2000;74(5):2293-304.

31. Gosert R, Egger D, Lohmann V, Bartenschlager R, Blum HE, Bienz K, et al. Identification of the hepatitis $C$ virus RNA replication complex in Huh-7 cells harboring subgenomic replicons. J Virol 2003;77(9):548792.

32. Enomoto $\mathrm{N}$, Sakuma I, Asahina $\mathrm{Y}$, Kurosaki M, Murakami T, Yamamoto $\mathrm{C}$, et al. Mutations in the nonstructural protein $5 \mathrm{~A}$ gene and response to interferon in patients with chronic hepatitis $C$ virus $1 b$ infection. N Engl J Med 1996;334(2):77-81.

33. Gale M Jr BC, kwieciszewski B, Tan SL, Dossett M, Tang N, Korth MJ et al. Control of PKR protein kinase by hepatitis $C$ virus nonstructural $5 \mathrm{~A}$ protein: molecular mechanisms of kinase regulation. Mol Cell Biol 1998;18:5208-5218.

34. Kimura M. The neutral theory of molecular evolution. Cambridge: Cambridge University Press; 1983.

35. Simmonds P. Genetic diversity and evolution of hepatitis C virus--15 years on. J Gen Virol 2004;85(Pt 11):3173-88.

36. Simmonds P, Bukh J, Combet C, Deleage G, Enomoto N, Feinstone $\mathrm{S}$, et al. Consensus proposals for a unified system of nomenclature of hepatitis C virus genotypes. Hepatology 2005;42(4):962-73.

37. Neumann AU, Lam NP, Dahari H, Gretch DR, Wiley TE, Layden TJ, et al. Hepatitis $\mathrm{C}$ viral dynamics in vivo and the antiviral efficacy of interferon-alpha therapy. Science 1998;282(5386):103-7. 
38. Simmonds P, Alberti A, Alter HJ, Bonino F, Bradley DW, Brechot C, et al. A proposed system for the nomenclature of hepatitis $C$ viral genotypes. Hepatology 1994;19(5):1321-4.

39. Farci P, Alter HJ, Govindarajan S, Wong DC, Engle R, Lesniewski RR, et al. Lack of protective immunity against reinfection with hepatitis $\mathrm{C}$ virus. Science 1992;258(5079):135-40.

40. Kalinina $\mathrm{O}$, Norder $\mathrm{H}$, Mukomolov S, Magnius LO. A natural intergenotypic recombinant of hepatitis $\mathrm{C}$ virus identified in St. Petersburg. J Virol 2002;76(8):4034-43.

41. Kalinina $\mathrm{O}$, Norder $\mathrm{H}$, Magnius LO. Full-length open reading frame of a recombinant hepatitis $C$ virus strain from St Petersburg: proposed mechanism for its formation. J Gen Virol 2004;85(Pt 7):1853-7.

42. Colina R, Casane D, Vasquez S, Garcia-Aguirre L, Chunga A, Romero $\mathrm{H}$, et al. Evidence of intratypic recombination in natural populations of hepatitis C virus. J Gen Virol 2004;85(Pt 1):31-7.

43. Noppornpanth S, Lien TX, Poovorawan Y, Smits SL, Osterhaus AD, Haagmans BL. Identification of a naturally occurring recombinant genotype 2/6 hepatitis C virus. J Virol 2006;80(15):7569-77.

44. Simmonds $\mathrm{P}$, Holmes EC, Cha TA, Chan SW, McOmish F, Irvine B, et al. Classification of hepatitis $C$ virus into six major genotypes and a series of subtypes by phylogenetic analysis of the NS-5 region. J Gen Virol 1993;74 (Pt 11):2391-9.

45. Robertson B, Myers G, Howard C, Brettin T, Bukh J, Gaschen B, et al. Classification, nomenclature, and database development for hepatitis $\mathrm{C}$ virus $(\mathrm{HCV})$ and related viruses: proposals for standardization. International Committee on Virus Taxonomy. Arch Virol 1998;143(12):2493-503.

46. Zein NN, Rakela J, Krawitt EL, Reddy KR, Tominaga T, Persing DH. Hepatitis C virus genotypes in the United States: epidemiology, pathogenicity, and response to interferon therapy. Collaborative Study Group. Ann Intern Med 1996;125(8):634-9.

47. Richter SS. Laboratory assays for diagnosis and management of hepatitis C virus infection. J Clin Microbiol 2002;40(12):4407-12.

48. Nousbaum JB PS, Nalpas B, Landais $P$, Berthekot $P$, Bréchot $C$ and colaborative study group. Hepatitis $C$ virus type $1 \mathrm{~b}(\mathrm{II})$ infection in France and Italy. Ann. Intern. Med 1995;122:161-168.

49. Takada N TS, Takeda A, Date T. Differences in the hepatitis C virus genotypes in different countries. J. Hepatology 1993;17. 
50. Candotti D, Temple J, Sarkodie F, Allain JP. Frequent recovery and broad genotype 2 diversity characterize hepatitis $C$ virus infection in Ghana, West Africa. J Virol 2003;77(14):7914-23.

51. Ndjomou J, Pybus OG, Matz B. Phylogenetic analysis of hepatitis C virus isolates indicates a unique pattern of endemic infection in Cameroon. J Gen Virol 2003;84(Pt 9):2333-41.

52. Mellor J, Holmes EC, Jarvis LM, Yap PL, Simmonds P. Investigation of the pattern of hepatitis $\mathrm{C}$ virus sequence diversity in different geographical regions: implications for virus classification. The International HCV Collaborative Study Group. J Gen Virol 1995;76 (Pt 10):2493-507.

53. Campiotto S, Pinho JR, Carrilho FJ, Da Silva LC, Souto FJ, Spinelli V, et al. Geographic distribution of hepatitis $C$ virus genotypes in Brazil. Braz J Med Biol Res 2005;38(1):41-9.

54. Holland PM, Abramson RD, Watson R, Gelfand DH. Detection of specific polymerase chain reaction product by utilizing the $5^{\prime}---3^{\prime}$ exonuclease activity of Thermus aquaticus DNA polymerase. Proc Natl Acad Sci U S A 1991;88(16):7276-80.

55. Silva CM, Costi C, Krug LP, Ramos AB, Grandi T, Gandolfi VL, et al. High proportion of hepatitis $C$ virus genotypes 1 and 3 in a large cohort of patients from Southern Brazil. Mem Inst Oswaldo Cruz 2007;102(7):867-70.

56. Espirito-Santo MP, Carneiro MA, Reis NR, Kozlowski AG, Teles SA, Lampe E, et al. Genotyping hepatitis $C$ virus from hemodialysis patients in Central Brazil by line probe assay and sequence analysis. Braz J Med Biol Res 2007;40(4):545-50.

57. Levi JE TD, Garrini RH, Fachini RM, Focaccia R, Santos, EB, Mitre HP, Mendonça JS, Cavalheiro NP, Barone AA, Wendel S. Three cases of infection with hepatitis $C$ virus genotype 5 among Brazilian hepatitis patients. J. Clin. Microbiol. 2002;40(7):2645-2647.

58. Nakatani SM ZC, Misugi H, Buba D, Rocha S, Lacerda MA, Muzzillo $D$, Parolin M. Prevalence of different hepatitis $C$ virus genotypes in the state of Paraná. (Abstract). Virus Reviews \& Research 2003;v 8 Suppl 1.

59. Sharma P BV, Hernandez J, Rosati M, Williams J, Rodriguez IH, Schwartz J, Harrison E, Anderson M, Byrne T, Vargas HE, Doug DD, Rakela J. Hepatic steatosis in hepatitis C virus genotype 3 infection: 
do correlate with body mass index, fibrosis, and HCV risk factor. Dig Dis Sci. 2004;49(1):25-29.

60. Kumar D, Farrell GC, Fung C, George J. Hepatitis C virus genotype 3 is cytopathic to hepatocytes: Reversal of hepatic steatosis after sustained therapeutic response. Hepatology 2002;36(5):1266-72.

61. Rubbia-Brandt L, Fabris P, Paganin S, Leandro G, Male PJ, Giostra E, et al. Steatosis affects chronic hepatitis $C$ progression in a genotype specific way. Gut 2004;53(3):406-12.

62. Serfaty L P-RA, Carbonell N, Chazouilleres O, Poupon R, Poupon R. Effect of the interaction between steatosis and alcohol intake liver fibrosis progression in chronic hepatitis C. Am J Gastroenterol 2002;97(7):1807-1812.

63. Hadziyannis SJ, Sette H, Jr., Morgan TR, Balan V, Diago M, Marcellin $\mathrm{P}$, et al. Peginterferon-alpha2a and ribavirin combination therapy in chronic hepatitis $\mathrm{C}$ : a randomized study of treatment duration and ribavirin dose. Ann Intern Med 2004;140(5):346-55.

64. Gane EJ, Naoumov NV, Qian KP, Mondelli MU, Maertens G, Portmann BC, et al. A longitudinal analysis of hepatitis C virus replication following liver transplantation. Gastroenterology 1996;110(1):167-77.

65. Di Martino V, Brenot C, Samuel D, Saurini F, Paradis V, Reynes M, et al. Influence of liver hepatitis $C$ virus RNA and hepatitis $C$ virus genotype on FAS-mediated apoptosis after liver transplantation for hepatitis C. Transplantation 2000;70(9):1390-6.

66. NIH. Consensus Statement on Management of hepatitis C. In: $\mathrm{NIH}$ Consensus State Sci Statements; 2002; 2002. p. 1-46.

67. McHutchison JG, Gordon SC, Schiff ER, Shiffman ML, Lee WM, Rustgi VK, et al. Interferon alfa-2b alone or in combination with ribavirin as initial treatment for chronic hepatitis C. Hepatitis Interventional Therapy Group. N Engl J Med 1998;339(21):1485-92.

68. Zeuzem S, Buti M, Ferenci P, Sperl J, Horsmans Y, Cianciara J, et al. Efficacy of 24 weeks treatment with peginterferon alfa-2b plus ribavirin in patients with chronic hepatitis $C$ infected with genotype 1 and low pretreatment viremia. J Hepatol 2006;44(1):97-103.

69. Chevaliez S PJ. Hepatitis C virus: Virology, diagnosis and management of antiviral therapy. World $\mathrm{J}$ Gastroenterology 2007;13(17):2461-2466.

70. Davis GL, Wong JB, McHutchison JG, Manns MP, Harvey J, Albrecht $J$. Early virologic response to treatment with peginterferon alfa-2b plus 
ribavirin in patients with chronic hepatitis C. Hepatology 2003;38(3):645-52.

71. Pawlotsky JM. Use and interpretation of virological tests for hepatitis C. Hepatology 2002;36(5 Suppl 1):S65-73.

72. Poynard T, Marcellin P, Lee SS, Niederau C, Minuk GS, Ideo G, et al. Randomised trial of interferon alpha2b plus ribavirin for 48 weeks or for 24 weeks versus interferon alpha2b plus placebo for 48 weeks for treatment of chronic infection with hepatitis $\mathrm{C}$ virus. International Hepatitis Interventional Therapy Group (IHIT). Lancet 1998;352(9138):1426-32.

73. Manns MP, McHutchison JG, Gordon SC, Rustgi VK, Shiffman M, Reindollar $R$, et al. Peginterferon alfa-2b plus ribavirin compared with interferon alfa-2b plus ribavirin for initial treatment of chronic hepatitis C: a randomised trial. Lancet 2001;358(9286):958-65.

74. Fried MW SM, Reddy KR, Smith C, Marinos G, Goncales FL, Haussinger D, Diago M, Carosi G, Dhuumeaux D, Craxi A, Lin a, Hoffman J, Yu J. Peginterferon alfa2a plus ribavirin for chroic hepatitis C virus infection. N. Engl J Med 2002;347:975-982.

75. Dalgard O, Bjoro K, Hellum KB, Myrvang B, Ritland S, Skaug K, et al. Treatment with pegylated interferon and ribavarin in $\mathrm{HCV}$ infection with genotype 2 or 3 for 14 weeks: a pilot study. Hepatology 2004;40(6):1260-5.

76. Chinchai T, Labout J, Noppornpanth S, Theamboonlers A, Haagmans $\mathrm{BL}$, Osterhaus AD, et al. Comparative study of different methods to genotype hepatitis $\mathrm{C}$ virus type 6 variants. J Virol Methods 2003;109(2):195-201.

77. Mellor J, Walsh EA, Prescott LE, Jarvis LM, Davidson F, Yap PL, et al. Survey of type 6 group variants of hepatitis $C$ virus in Southeast Asia by using a core-based genotyping assay. $J$ Clin Microbiol 1996;34(2):417-23.

78. Vatteroni M, Maggi F, Morrica A, Fornai C, Giorgi M, Pistello M, et al. Comparative evaluation of five rapid methods for identifying subtype $1 \mathrm{~b}$ and 2c hepatitis C virus isolates. J Virol Methods 1997;66(2):18794.

79. Chen Z, Weck KE. Hepatitis C virus genotyping: interrogation of the $5^{\prime}$ untranslated region cannot accurately distinguish genotypes 1a and 1b. J Clin Microbiol 2002;40(9):3127-34.

80. Cantaloube JF, Laperche S, Gallian P, Bouchardeau F, de Lamballerie $X$, de Micco $P$. Analysis of the 5 ' noncoding region versus 
the NS5b region in genotyping hepatitis $C$ virus isolates from blood donors in France. J Clin Microbiol 2006;44(6):2051-6.

81. Corbet S, Bukh J, Heinsen A, Fomsgaard A. Hepatitis C virus subtyping by a core-envelope 1-based reverse transcriptase PCR assay with sequencing and its use in determining subtype distribution among Danish patients. J Clin Microbiol 2003;41(3):1091-100.

82. Germer JJ, Rys PN, Thorvilson JN, Persing DH. Determination of hepatitis $\mathrm{C}$ virus genotype by direct sequence analysis of products generated with the Amplicor HCV test. J Clin Microbiol 1999;37(8):2625-30.

83. Bukh J, Miller $\mathrm{RH}$, Purcell $\mathrm{RH}$. Genetic heterogeneity of hepatitis $\mathrm{C}$ virus: quasispecies and genotypes. Semin Liver Dis 1995;15(1):41-63.

84. Weck K. Molecular methods of hepatitis $\mathrm{C}$ genotyping. Expert Rev Mol Diagn 2005;5(4):507-20.

85. Laperche S, Lunel F, Izopet J, Alain S, Deny P, Duverlie G, et al. Comparison of hepatitis C virus NS5b and $5^{\prime}$ noncoding gene sequencing methods in a multicenter study. J Clin Microbiol 2005;43(2):733-9.

86. Okamoto H, Sugiyama $Y$, Okada S, Kurai K, Akahane $Y$, Sugai $Y$, et al. Typing hepatitis $C$ virus by polymerase chain reaction with typespecific primers: application to clinical surveys and tracing infectious sources. J Gen Virol 1992;73 (Pt 3):673-9.

87. Ohno O, Mizokami M, Wu RR, Saleh MG, Ohba K, Orito E, et al. New hepatitis $\mathrm{C}$ virus (HCV) genotyping system that allows for identification of HCV genotypes $1 \mathrm{a}, 1 \mathrm{~b}, 2 \mathrm{a}, 2 \mathrm{~b}, 3 \mathrm{a}, 3 \mathrm{~b}, 4,5 \mathrm{a}$, and $6 \mathrm{a}$. J Clin Microbiol 1997;35(1):201-7.

88. Furione M SL, Gatti M, Baldanti F, Grazia Revello M, Gerna G. HCV genotyping by three methods analysis of discordant results based on sequencing. J. Clin. Virol 1999;13(3):121-130.

89. Nakao T, Enomoto N, Takada N, Takada A, Date T. Typing of hepatitis $\mathrm{C}$ virus genomes by restriction fragment length polymorphism. J Gen Virol 1991;72 (Pt 9):2105-12.

90. Pohjanpelto $\mathrm{P}$, Lappalainen M, Widell A, Asikainen K, Paunio M. Hepatitis $\mathrm{C}$ genotypes in Finland determined by RFLP. Clin Diagn Virol 1996;7(1):7-16.

91. Anderson JC, Simonetti J, Fisher DG, Williams J, Yamamura Y, Rodriguez N, et al. Comparison of different HCV viral load and genotyping assays. J Clin Virol 2003;28(1):27-37. 
92. Davidson F, Simmonds P, Ferguson JC, Jarvis LM, Dow BC, Follett $E A$, et al. Survey of major genotypes and subtypes of hepatitis $C$ virus using RFLP of sequences amplified from the $5^{\prime}$ non-coding region. J Gen Virol 1995;76 (Pt 5):1197-204.

93. Mullis KB FF. Specific synthesis of DNA in vitro via polymerase catalyzed chain reaction. Methods Enzymol 1987;155:335-350.

94. Watzinger F, Ebner K, Lion T. Detection and monitoring of virus infections by real-time PCR. Mol Aspects Med 2006;27(2-3):254-98.

95. Higuchi R, Dollinger G, Walsh PS, Griffith R. Simultaneous amplification and detection of specific DNA sequences. Biotechnology (N Y) 1992;10(4):413-7.

96. Kubista M, Andrade JM, Bengtsson M, Forootan A, Jonak J, Lind K, et al. The real-time polymerase chain reaction. Mol Aspects Med 2006;27(2-3):95-125.

97. Zipper H, Brunner H, Bernhagen J, Vitzthum F. Investigations on DNA intercalation and surface binding by SYBR Green I, its structure determination and methodological implications. Nucleic Acids Res 2004;32(12):e103.

98. Bengtsson M, Karlsson HJ, Westman G, Kubista M. A new minor groove binding asymmetric cyanine reporter dye for real-time PCR. Nucleic Acids Res 2003;31(8):e45.

99. Selvin PR. Fluorescence resonance energy transfer. Methods Enzymol 1995;246:300-34.

100. Kutyavin IV, Afonina IA, Mills A, Gorn VV, Lukhtanov EA, Belousov $E S$, et al. 3'-minor groove binder-DNA probes increase sequence specificity at PCR extension temperatures. Nucleic Acids Res 2000;28(2):655-61.

101. Kubista M. Nucleic acid based techonologies: applications amplified. Pharmacogenomic 2004;5(7):767-73.

102. Caplin BD RR, Bernard PS, Wittwer CT. LightCycler - Hybridization probes The most direct way to monitor PCR amplification for quantification and mutation detection. Biomedica 1999;1:5-8.

103. Tyagi S, Kramer FR. Molecular beacons: probes that fluoresce upon hybridization. Nat Biotechnol 1996;14(3):303-8.

104. Whitcombe D, Theaker J, Guy SP, Brown T, Little S. Detection of PCR products using self-probing amplicons and fluorescence. Nat Biotechnol 1999;17(8):804-7. 
105. Nazarenko I, Lowe B, Darfler M, Ikonomi P, Schuster D, Rashtchian A. Multiplex quantitative PCR using self-quenched primers labeled with a single fluorophore. Nucleic Acids Res 2002;30(9):e37.

106. Moghaddam A, Reinton N, Dalgard O. A rapid real-time PCR assay for determination of hepatitis $C$ virus genotypes 1, 2 and 3a. J Viral Hepat 2006;13(4):222-9.

107. Rolfe KJ, Alexander GJ, Wreghitt TG, Parmar S, Jalal H, Curran MD. A real-time Taqman method for hepatitis $C$ virus genotyping. J Clin Virol 2005;34(2):115-21.

108. Lindh M, Hannoun C. Dynamic range and reproducibility of hepatitis $B$ virus (HBV) DNA detection and quantification by Cobas Taqman HBV, a real-time semiautomated assay. J Clin Microbiol 2005;43(8):4251-4.

109. Bullock GC, Bruns DE, Haverstick DM. Hepatitis C genotype determination by melting curve analysis with a single set of fluorescence resonance energy transfer probes. Clin Chem 2002;48(12):2147-54.

110. Haverstick DM, Bullock GC, Bruns DE. Genotyping of hepatitis C virus by melting curve analysis: analytical characteristics and performance. Clin Chem 2004;50(12):2405-7.

111. Schroter M, Zollner B, Schafer P, Landt O, Lass U, Laufs R, et al. Genotyping of hepatitis C virus types 1,2, 3, and 4 by a one-step LightCycler method using three different pairs of hybridization probes. J Clin Microbiol 2002;40(6):2046-50.

112. Fujigaki $H$, Takemura $M$, Takahashi $K$, Yamada $Y$, Fujii $H$, Wada $H$, et al. Genotyping of hepatitis $\mathrm{C}$ virus by melting curve analysis with SYBR Green I. Ann Clin Biochem 2004;41(Pt 2):130-2.

113. Elahi E, Pourmand N, Chaung R, Rofoogaran A, Boisver J, SamimiRad K, et al. Determination of hepatitis $C$ virus genotype by Pyrosequencing. J Virol Methods 2003;109(2):171-6.

114. White PA, Zhai X, Carter I, Zhao Y, Rawlinson WD. Simplified hepatitis $\mathrm{C}$ virus genotyping by heteroduplex mobility analysis. J Clin Microbiol 2000;38(2):477-82.

115. Calvo PL, Kansopon J, Sra K, Quan S, DiNello R, Guaschino R, et al. Hepatitis C virus heteroduplex tracking assay for genotype determination reveals diverging genotype 2 isolates in Italian hemodialysis patients. J Clin Microbiol 1998;36(1):227-33. 
116. Murphy DG, Willems B, Deschenes M, Hilzenrat N, Mousseau R, Sabbah S. Use of sequence analysis of the NS5B region for routine genotyping of hepatitis $C$ virus with reference to $C / E 1$ and $5^{\prime}$ untranslated region sequences. J Clin Microbiol 2007;45(4):1102-12.

117. Tokita H, Okamoto H, Tsuda F, Song P, Nakata S, Chosa T, et al. Hepatitis $C$ virus variants from Vietnam are classifiable into the seventh, eighth, and ninth major genetic groups. Proc Natl Acad Sci U S A 1994;91(23):11022-6.

118. Stuyver L, Rossau R, Wyseur A, Duhamel M, Vanderborght B, Van Heuverswyn $\mathrm{H}$, et al. Typing of hepatitis $C$ virus isolates and characterization of new subtypes using a line probe assay. J Gen Virol 1993;74 (Pt 6):1093-102.

119. Ross RS, Viazov SO, Holtzer CD, Beyou A, Monnet A, Mazure C, et al. Genotyping of hepatitis $C$ virus isolates using CLIP sequencing. J Clin Microbiol 2000;38(10):3581-4.

120. Payne DA, Seifert SL, Brody BA. Effects of storage and viral load on hepatitis C viral genotyping. J Clin Lab Anal 2001;15(6):331-3.

121. Germer JJ, Majewski DW, Yung B, Mitchell PS, Yao JD. Evaluation of the invader assay for genotyping hepatitis $\mathrm{C}$ virus. J Clin Microbiol 2006;44(2):318-23.

122. Schutzbank TE SS, Kahmann N, Li H, Tang Yi-Wei. Comparatve evaluation of three commercially available methodologies for Hepatitis C virus Genotyping. J Clini. Microbiol. 2006;44(10):3797-3798.

123. Radziewicz H NF. Genotyping of hepatitis $\mathrm{C}$ virus (HCV) using a real time polymerase chain reaction (PCR) assay. J. Mol. Diagn. 2004;6(4):425.

124. Cook L, Sullivan K, Krantz EM, Bagabag A, Jerome KR. Multiplex realtime reverse transcription-PCR assay for determination of hepatitis $\mathrm{C}$ virus genotypes. J Clin Microbiol 2006;44(11):4149-56.

125. Othman SB, Trabelsi A, Monnet A, Bouzgarrou N, Grattard F, Beyou A, et al. Evaluation of a prototype HCV NS5b assay for typing strains of hepatitis $C$ virus isolated from Tunisian haemodialysis patients. J Virol Methods 2004;119(2):177-81.

126. Viazov S, Zibert A, Ramakrishnan K, Widell A, Cavicchini A, Schreier $E$, et al. Typing of hepatitis $C$ virus isolates by DNA enzyme immunoassay. J Virol Methods 1994;48(1):81-91. 
127. Sandres K, Dubois M, Pasquier C, Puel J, Izopet J. Determination of HCV genotype using two antibody assays and genome typing. Eur $\mathrm{J}$ Clin Microbiol Infect Dis 2001;20(9):666-9.

128. Dixit V, Quan S, Martin P, Larson D, Brezina M, DiNello R, et al. Evaluation of a novel serotyping system for hepatitis $C$ virus: strong correlation with standard genotyping methodologies. J Clin Microbiol 1995;33(11):2978-83.

129. Pawlotsky JM, Prescott L, Simmonds $P$, Pellet C, Laurent-Puig $P$, Labonne C, et al. Serological determination of hepatitis C virus genotype: comparison with a standardized genotyping assay. J Clin Microbiol 1997;35(7):1734-9.

130. Boom R, Sol CJ, Salimans MM, Jansen CL, Wertheim-van Dillen PM, van der Noordaa J. Rapid and simple method for purification of nucleic acids. J Clin Microbiol 1990;28(3):495-503.

131. Applied, Biosystems. Sequence Detection Systems. In; 2003. p. 3-12.

132. Hall T. Bioedit: a user friendly biological sequence aligment editor and analysis program for windows 95/98/NT. Nucleic Acids Symp Ser 1999;41:95-98.

133. Tamura K, Dudley J, Nei M, Kumar S. MEGA4: Molecular Evolutionary Genetics Analysis (MEGA) software version 4.0. Mol Biol Evol 2007;24(8):1596-9.

134. Paula VS VL, Gaspar AMC. Comparison of four extraction methods to detect hepatitis $C$ virus in serum and stool samples. The Brazilian Journal of Infectious Diseases 2004;7(2):135-141.

135. Poersch CO. Dengue virus infection: comparison of methods for diagnosing the acute disease. J Clin. Virol. 2005;32(4):272-277.

136. Thompson WD, Walter SD. Kappa and the concept of independent errors. J Clin Epidemiol 1988;41(10):969-70.

137. Timm J, Roggendorf M. Sequence diversity of hepatitis C virus: implications for immune control and therapy. World J Gastroenterol 2007;13(36):4808-17.

138. Bustin SA. Absolute quantification of mRNA using real-time reverse transcription polymerase chain reaction assays. $\mathrm{J}$ Mol Endocrinol 2000;25(2):169-93.

139. Stahlberg A, Hakansson J, Xian X, Semb H, Kubista M. Properties of the reverse transcription reaction in mRNA quantification. Clin Chem 2004;50(3):509-15. 
140. Bustin SA, Benes V, Nolan T, Pfaffl MW. Quantitative real-time RTPCR--a perspective. J Mol Endocrinol 2005;34(3):597-601.

141. Lekanne Deprez RH, Fijnvandraat AC, Ruijter JM, Moorman AF. Sensitivity and accuracy of quantitative real-time polymerase chain reaction using SYBR green I depends on cDNA synthesis conditions. Anal Biochem 2002;307(1):63-9.

142. Wacker MJ, Godard MP. Analysis of one-step and two-step real-time RT-PCR using SuperScript III. J Biomol Tech 2005;16(3):266-71.

143. Peters IR, Helps CR, Hall EJ, Day MJ. Real-time RT-PCR: considerations for efficient and sensitive assay design. J Immunol Methods 2004;286(1-2):203-17.

144. Stahlberg A, Kubista M, Pfaffl M. Comparison of reverse transcriptases in gene expression analysis. Clin Chem 2004;50(9):1678-80.

145. Tang YW, Sefers SE, Li H, Kohn DJ, Procop GW. Comparative evaluation of three commercial systems for nucleic acid extraction from urine specimens. J Clin Microbiol 2005;43(9):4830-3.

146. Schuurman T, de Boer R, Patty R, Kooistra-Smid M, van Zwet A. Comparative evaluation of in-house manual, and commercial semiautomated and automated DNA extraction platforms in the sample preparation of human stool specimens for a Salmonella enterica 5'nuclease assay. J Microbiol Methods 2007;71(3):238-45.

147. Loens K, Bergs K, Ursi D, Goossens H, leven M. Evaluation of NucliSens easyMAG for automated nucleic acid extraction from various clinical specimens. J Clin Microbiol 2007;45(2):421-5.

148. Stevens W, Horsfield P, Scott LE. Evaluation of the performance of the automated NucliSENS easyMAG and EasyQ systems versus the Roche AmpliPrep-AMPLICOR combination for high-throughput monitoring of human immunodeficiency virus load. J Clin Microbiol 2007;45(4):1244-9.

149. Nolte FS, Green AM, Fiebelkorn KR, Caliendo AM, Sturchio C, Grunwald $A$, et al. Clinical evaluation of two methods for genotyping hepatitis $\mathrm{C}$ virus based on analysis of the $5^{\prime}$ noncoding region. J Clin Microbiol 2003;41(4):1558-64.

150. Kato N. Molecular virology of hepatitis C virus. Acta Med Okayama 2001;55(3):133-59. 
151. Aiken C MR, Jardine D, Bowden S, Higgs $P$, Nguyen $O$, Crofts $N$, Hellard $M$. Change in hepatitis $C$ virus genotype in infecting drug users. J Med. Virol 2004;74:543-545.

152. Tuveri R RC, Pol S, Reijasse D, Persico T, Gazengel C, Brechot C, Thiers V. Hepatitis C virus genotypes in French haemophilics: kineticsa and reappraisal of mixed infection. J. Med. Virol 1997;51:3641.

153. Qian KP NS, Pereira BJG, Lau JYN. Hepatitis C virus mixed genotype infection in patients on haemodialysis. J. Viral Hepat. 2000;7(153160).

154. Mitchell PS, Sloan LM, Majewski DW, Rys PN, Heimgartner PJ, Rosenblatt JE, et al. Comparison of line probe assay and DNA sequencing of $5^{\prime}$ untranslated region for genotyping hepatitis $C$ virus: description of novel line probe patterns. Diagn Microbiol Infect Dis 2002;42(3):175-9.

155. Buckton AJ, Ngui SL, Arnold C, Boast K, Kovacs J, Klapper PE, et al. Multitypic hepatitis $C$ virus infection identified by real-time nucleotide sequencing of minority genotypes. J Clin Microbiol 2006;44(8):277984.

156. Martro E, Gonzalez V, Buckton AJ, Saludes V, Fernandez G, Matas L, et al. Evaluation of a new assay in comparison with reverse hybridization and sequencing methods for hepatitis $C$ virus genotyping targeting both 5 ' noncoding and nonstructural $5 \mathrm{~b}$ genomic regions. $J$ Clin Microbiol 2008;46(1):192-7.

157. Kusser W, Javorschi, S. Gleeson, MA. Protocol of Real-Time RTPCR:cDNA synthesis. CSH Protocols 2006 [cited; Available from:

158. Levi JE, Takaoka DT, Garrini RH, Fachini RM, Focaccia R, De Bortholi Santos E, et al. Three cases of infection with hepatitis $C$ virus genotype 5 among Brazilian hepatitis patients. J Clin Microbiol 2002;40(7):2645-7.

159. Holland PV, Barrera JM, Ercilla MG, Yoshida CF, Wang Y, de Olim $\mathrm{GA}$, et al. Genotyping hepatitis $\mathrm{C}$ virus isolates from Spain, Brazil, China, and Macau by a simplified PCR method. J Clin Microbiol 1996;34(10):2372-8. 